\title{
11. GABBROIC ROCKS TRAPPED IN THE UPPER MANTLE AT THE MID-ATLANTIC RIDGE ${ }^{1}$
}

\author{
Mathilde Cannat, ${ }^{2}$ Fabienne Chatin, ${ }^{3}$ Hubert Whitechurch, ${ }^{3}$ and Georges Ceuleneer ${ }^{4}$
}

\begin{abstract}
The ultramafic rocks drilled at Site 920 are intruded by dikes, dikelets, and impregnation lenses of texturally, mineralogically, and chemically diverse gabbroic rocks. These rocks represent about $4 \%$ in volume of the core recovered at Site 920 . They range from impregnation lenses with magnesium-rich clinopyroxene and calcic plagioclase, to zircon-bearing dikelets with iron-rich clinopyroxene and sodium-rich plagioclase. In terms of mineralogy and chemical diversity, they are similar to gabbroic rocks that form large outcrops a few tens of kilometers north of Site 920 (Sites 921-924) and to rocks drilled near the Southwest Indian Ridge at Site 735. The chemical diversity of gabbroic rocks recovered at Site 920 is reflected in their order of crystallization in the peridotites, the most primitive rocks crystallizing first, and the most fractionated ones, last. Chemical modifications in the ultramafic rocks near the gabbroic intrusions range from the formation of decimeter-thick dunite screens to cryptic variations in olivine $\mathrm{Mg \#}$ and nickel content, in clinopyroxene sodium content, and in spinel $\mathrm{Mg} \#$ and titanium content. We propose a model in which the gabbroic rocks recovered at Site 920 crystallized from melts that had undergone variable degrees of differentiation in a root of lithospheric mantle beneath the Mid-Atlantic Ridge.
\end{abstract}

\section{INTRODUCTION}

Site 920 was drilled at $23^{\circ} 20.3^{\prime} \mathrm{N}$ and $45^{\circ} 01^{\prime} \mathrm{W}$ in serpentinized peridotites that crop out along the west wall of the Mid-Atlantic Ridge axial valley (Fig. 1), about $20 \mathrm{~km}$ to the north of Ocean Drilling Program (ODP) Site 670 (Shipboard Scientific Party, 1988). Similar serpentinized peridotites have also been dredged (Cannat et al., 1995), drilled (Shipboard Scientific Party, 1979), and sampled by submersible (J. Dubois et al., unpubl. data; Auzende et al., 1993), offaxis to the west of Site 920 (Fig. 1), and have therefore commonly been emplaced in the upper levels of the oceanic crust of this region, at least during the last few million years.

Submersible studies (Karson et al., 1987; Mével et al., 1991) have shown that the serpentinized peridotites that crop out on the west median valley wall are directly overlain by pillow basalts and lava flows, with no intervening outcrops of gabbroic rocks that could represent the lower part of the magmatic crust. Gabbroic rocks are, however, common as dikelets and dikes in the ultramafic rocks (Tartarotti et al., 1995; this study), and they form wide outcrops further north near the Kane Fracture Zone (Fig. 1). This map distribution suggests that the lower magmatic crust in this region of the Mid-Atlantic Ridge is laterally discontinuous, at a scale of a few kilometers to a few tens of kilometers. This geological pattern is not unique to the Mid-Atlantic Ridge near the Kane Fracture Zone (MARK area), as ultramafic outcrops are common in other parts of the slow-spreading Atlantic (Aumento, Melson, et al., 1977; Bougalt, Cande, et al., 1985; Bonatti et al., 1992) and along the Southwest Indian Ridge (Dick, 1989). Understanding the modes of formation of such a discontinuous lower magmatic crust would therefore be a step toward understanding the architecture of significant portions of the lithosphere created at slowspreading ridges.

'Karson, J.A., Cannat, M., Miller, D.J., and Elthon, D. (Eds.), 1997. Proc. ODP, Sci. Results, 153: College Station, TX (Ocean Drilling Program).

2Laboratoire de Pétrologie-URA CNRS 736, Université Pierre et Marie Curie, 4 place Jussieu, 75252 Paris cedex 05, France. mac@ccr.jussieu.fr

3Département des Sciences de la Terre, Université de La Rochelle, av, de Marillac, 17042 La Rochelle cedex 1, France.

4Observatoire Midi-Pyrénées, CNRS-UPR 234, 14 av. E. Belin, 31400 Toulouse, France.

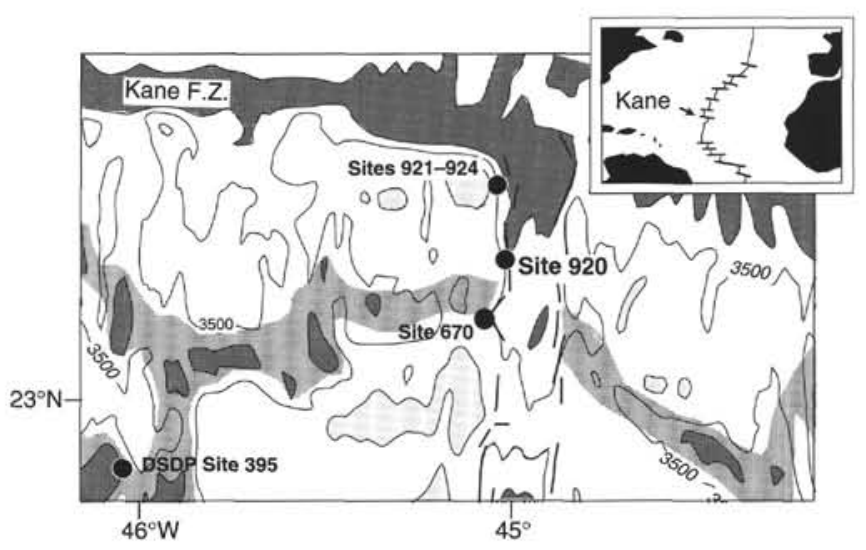

Figure 1. Simplified bathymetric map of the MARK area (Mid-Atlantic Ridge/Kane Fracture Zone; after Gente et al., 1995) with location of Sites 395 (Deep Sea Drilling Project Leg 45; serpentinized peridotites and gabbros), 670 (ODP Leg 109; serpentinized peridotites), 920 (this study), and 921-924 (Leg 153; gabbros). Bathymetric contours: $4000 \mathrm{~m}$ (domains deeper than $4000 \mathrm{~m}$ in dark gray), $3500 \mathrm{~m}$, and $2500 \mathrm{~m}$ (domains shallower than $2500 \mathrm{~m}$ in lighter gray). Heavy lines show the median valley main scarps. Alignments of basins, interpreted as marking the off-axis trace of axial discontinuities, are outlined in an intermediate shade of gray.

Two processes have been proposed to explain the discontinuous nature of the lower magmatic crust: (1) tectonic dismembering along large offset faults and shear zones (Dick et al., 1981; Karson, 1990; Mével et al. 1991; Cannat et al., 1991), and (2) the crystallization of lower crustal magmatic rocks in isolated, unreplenished magma bodies, trapped at depth within the axial lithospheric mantle (Dick 1989; Cannat, 1993). Critical constraints in assessing the relative importance of these two processes in building a discontinuous lower magmatic crust are the magmatic and tectonic evolution of gabbroic and other coarse-grained magmatic rocks, as well as the nature of their contacts with residual ultramafic rocks, in regions where these residual rocks crop out.

The two successful holes (Holes 920B and 920D) drilled only 18 $\mathrm{m}$ apart at Site 920 have provided $142 \mathrm{~m}$ of core $(40 \%$ recovery at 


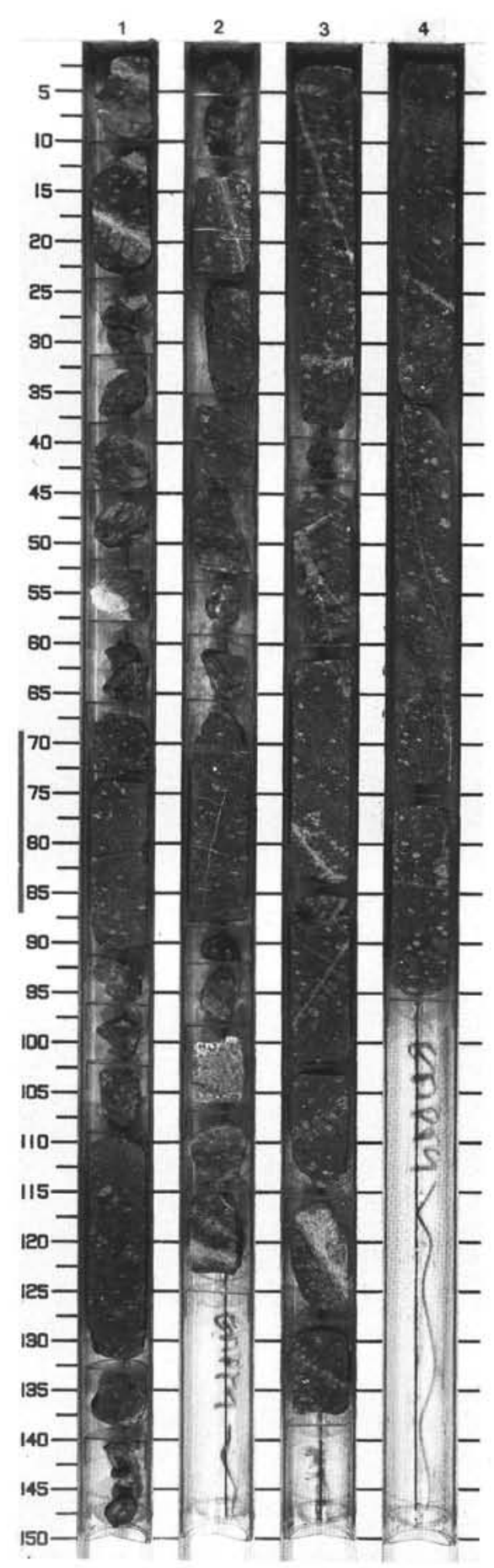

Figure 2. This interval from Core 153-920D-18R contains many gabbroic dikelets, eight of which have been studied for this paper (Table 2). Interval 153-920D-18R-2, 100-106 cm, is a medium-grained oxide-bearing gabbro. The ultramafic piece underneath contains plagioclase, clinopyroxene, and brown amphibole impregnations. The dikelets branching in interval 153920D-18R-3, 45-60 cm, are texturally similar to the dikelet pictured in Figure $3 \mathrm{C}$; they contain apatite, ilmenite, and brown amphibole. The thicker dikelet in interval $153-920 \mathrm{D}-18 \mathrm{R}-3,115-127 \mathrm{~cm}$, is an extensively altered gabbronorite. Many pieces of serpentinized harzburgite in this core are poor in orthopyroxene (light dots in darker matrix of serpentinized olivine). Also note that dikelets are commonly surrounded by lighter colored, less-serpentinized peridotite. This effect is seen throughout the core from Site 920 .
Hole $920 \mathrm{~B}, 47 \%$ at Hole 920D), of which $92.9 \%$ are serpentinized peridotites, $3.8 \%$ are variably altered dikelets and dikes of coarsegrained magmatic rocks, and $3.3 \%$ are diabase. Diabase samples belong to a single dike, $3-8 \mathrm{~m}$ thick, which was drilled in both holes around $80 \mathrm{~m}$ below seafloor (mbsf). Coarse-grained magmatic rocks form dikelets and dikes $0.1 \mathrm{~mm}$ to over $10 \mathrm{~cm}$ thick (Fig. 2). Gabbroic rocks also form decimeter-thick intervals in the core, which commonly have not preserved their contacts with the ultramafic rocks, but are assumed here to be dikes. In addition, clinopyroxene-impregnation lenses a few millimeters thick (Fig. 3A), are found in about $25 \%$ of the recovered ultramafic rocks (Fig. 4A). The purpose of this paper is to document the mineralogical and textural variability of the coarse-grained magmatic rocks recovered at Site 920, to provide constraints on the nature of the melts from which they crystallized, and also to constrain the relative timing and tectonic context of their emplacement in the ultramafic host rock.

\section{COARSE-GRAINED MAGMATIC ROCKS IN THE ULTRAMAFIC ROCKS}

\section{Downhole Distribution}

Coarse-grained, variably altered, magmatic rocks are found throughout the core recovered at Site 920 (Fig. 4; Table 1). A total of 561 dikelets and gabbroic intervals has been identified, the cumulated number of dikelets per meter of core (Fig. 4C) being comparable in Holes 920B (3.58) and 920D (4.37). Most dikelets are less than 1 $\mathrm{cm}$ thick, and dikelets over $5 \mathrm{~cm}$ thick are uncommon (Fig. 4). The thickest gabbroic interval $(0.81 \mathrm{~m}$ of core $)$ was found at the bottom of Hole 920B (Fig. 4B).

The number of dikelets per meter of core is variable: some intervals have up to 20 dikelets per meter, others have no dikelets at all (Fig. 4C). There is no correlation between the number of dikelets and their width, and there is no systematic trend in downhole variations of these characteristics. The longest interval of consistently high numbers of dikelets per meter of core was cored between 138 and 164 mbsf in Hole 920D (Fig. 4C).

The percentage of coarse-grained dikelets in each section of core (Fig. 4D) has been calculated by dividing the cumulate width of dikelets in the section by the section's length (Table 1). For horizontal dikelets, this value would represent the volume percent of dikelet material in the cored ultramafic rocks. Because dikelets at Site 920 are not horizontal as a rule (Shipboard Scientific Party, 1995), this value is a minimum estimate of true volumetric proportions. It averages $3.89 \%$ in the core from Hole $920 \mathrm{~B}$ and $3.74 \%$ in the core from Hole $920 \mathrm{D}$ (Table 1). Higher than average values of this percentage are associated with thicker than average individual dikelets, or with high numbers of dikelets per meter of core (Fig. 2).

Clinopyroxene-impregnation lenses less than $0.5 \mathrm{~cm}$ thick (Fig. $3 \mathrm{~A}$ ) and concordant with the shallow-dipping crystal-plastic foliation of the ultramafic rocks (Ceuleneer and Cannat, this volume) are found in about $25 \%$ of the ultramafic samples recovered at Site 920 (Fig. 4A). They are most common in core from the base of Hole 920B (Cores 920B-12R and 13R) and in Cores 153-920D-13R, 15R, 16R, and $17 R$. Their maximum cumulated abundance in the core can be estimated as $0.5 \%$, assuming that, when present, they form no more than $2 \%$ of the ultramafic material (Fig. 3A). Thicker clinopyroxeneimpregnation lenses (up to $3 \mathrm{~cm}$ thick) have been identified in only three samples (Samples 153-920B-8R-5, 108-114 cm; 153-920D13R-2, 64-68 cm; and 153-920D-15R-3, 19-22 cm).

\section{Primary Mineralogy and Texture}

The thinnest, and most numerous, dikelets recovered at Site 920 are extensively altered to chlorite and actinolite. Dikelets over $0.5 \mathrm{~cm}$ thick commonly contain relic primary minerals, usually pyroxene, 
A

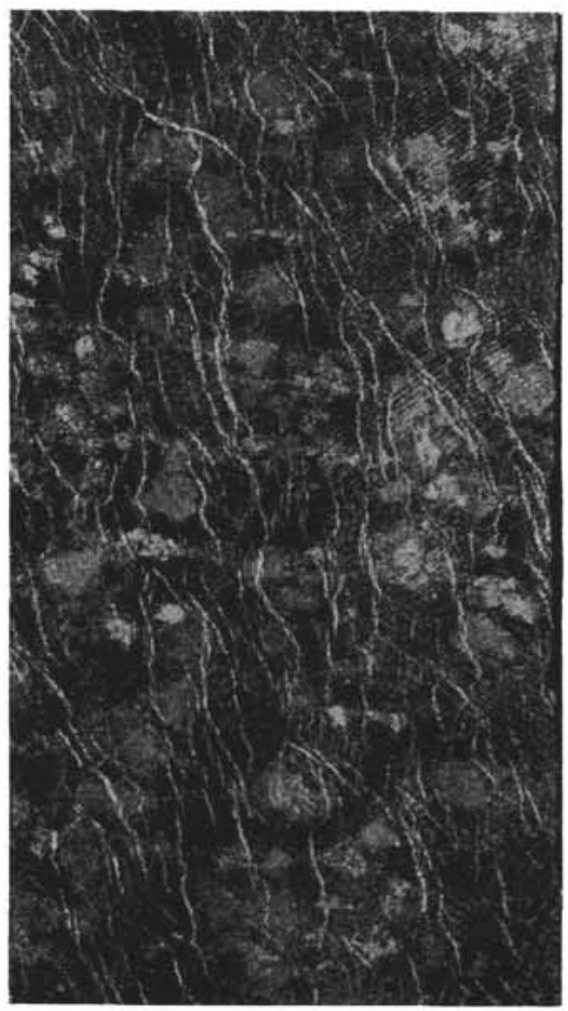

C

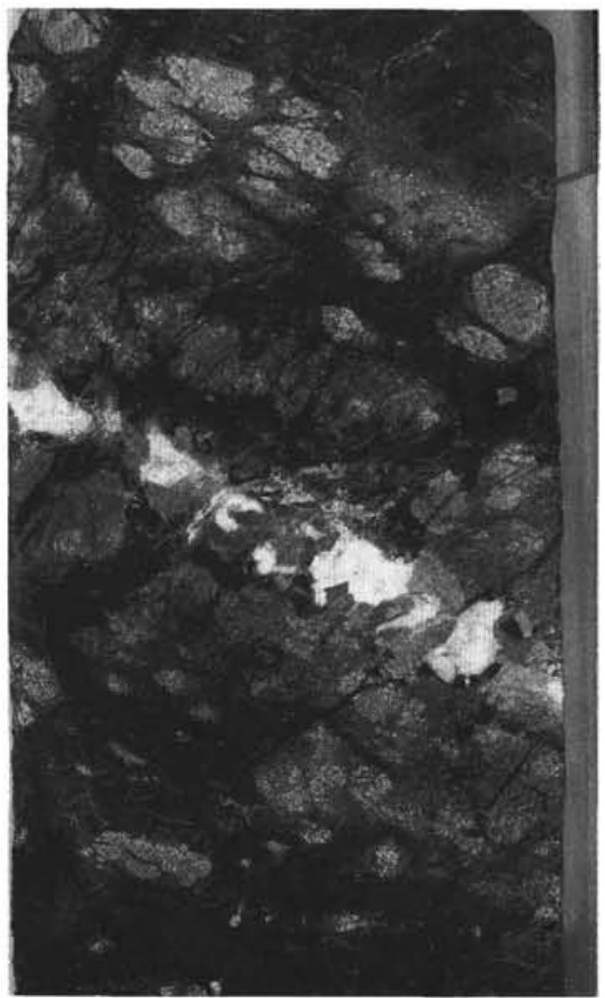

B

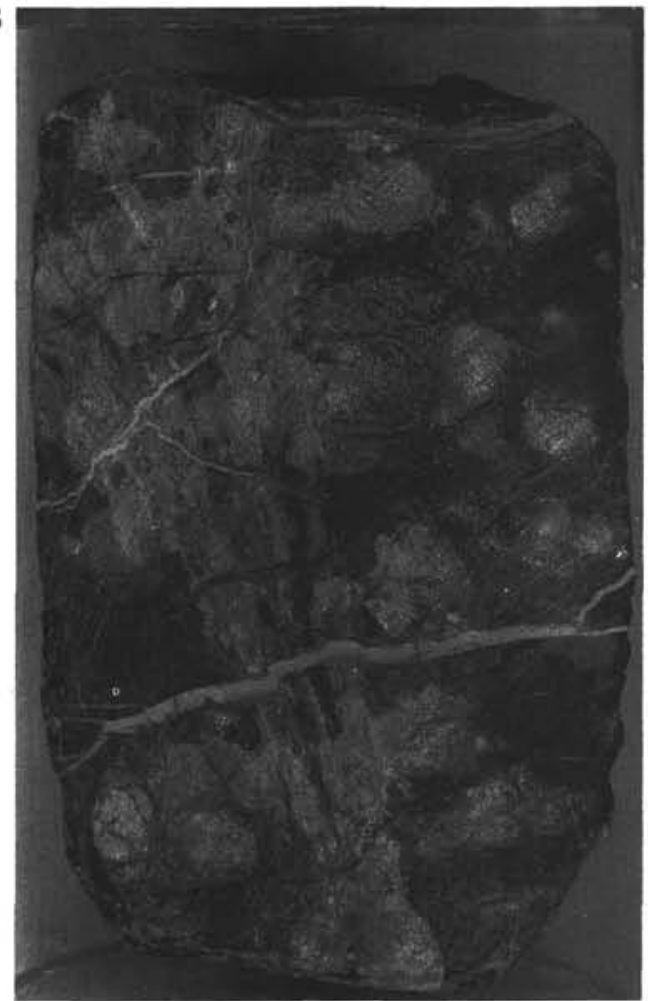

D

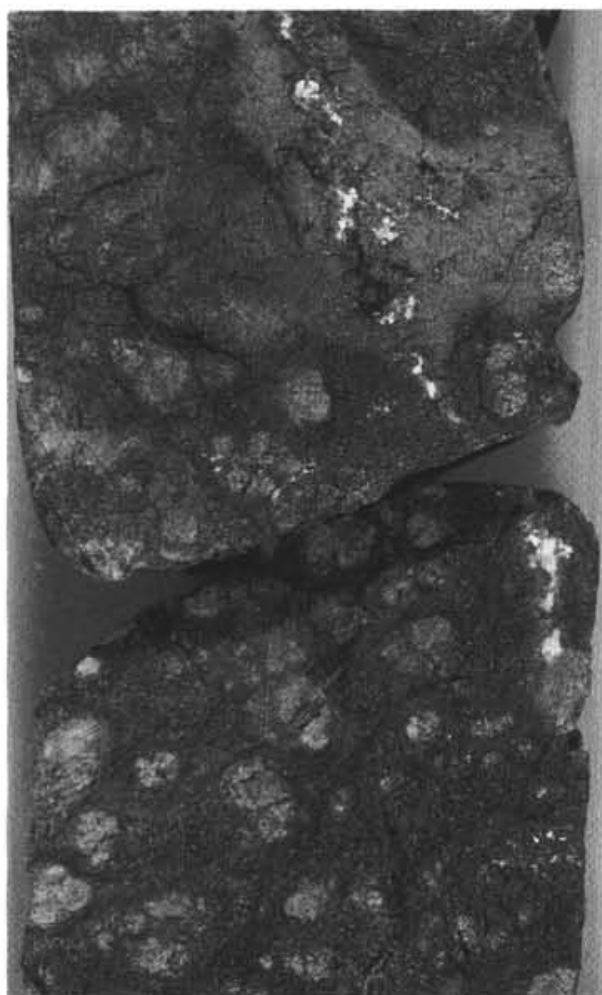

Figure 3. Core photographs from Site 920. A. Interval 153-920B-12R-2, 108-118 cm. Thin impregnation lenses of undeformed clinopyroxene in serpentinized harzburgite. Crystal-plastic spinel foliation in harzburgite (not visible here) is subhorizontal, parallel with clinopyroxene-impregnation lenses. Steep, light-colored, serpentine microcracks are prominent in this sample. B. Interval 153-920D-2R-1, 133-142 cm. Steep, fan-shaped mylonitic shear zone in serpentinized harzburgite. This mylonite involves dikelets of zircon-bearing gabbronorite (photomicrograph in Fig. 5A). C. Interval 153-920B-11R-1, 110-120 cm. Dikelet of coarse-grained gabbronorite in partly serpentinized harzburgite. Plagioclase (white) is altered. Euhedral pyroxenes in the dikelet have straight and clean contacts with minerals of the host harzburgite. D. Interval 153-920D-14R-2, 109-120 cm. Clinopyroxene- and plagiocase-impregnation lens in relatively fresh harzburgite. Light gray area in the peridotite near the impregnation at $111-113 \mathrm{~cm}$ is related to oxidative alteration, not to a local change in pyroxene modal proportions. 
A

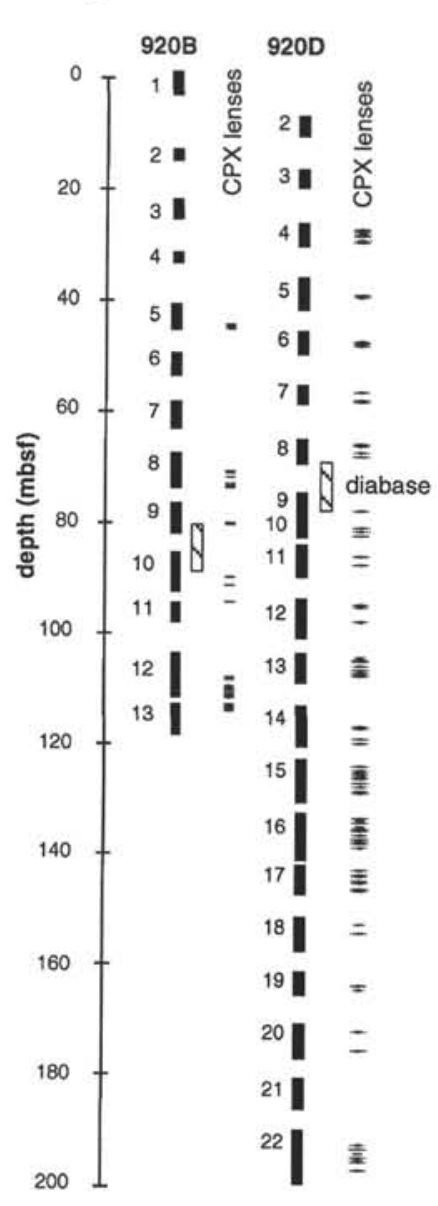

B

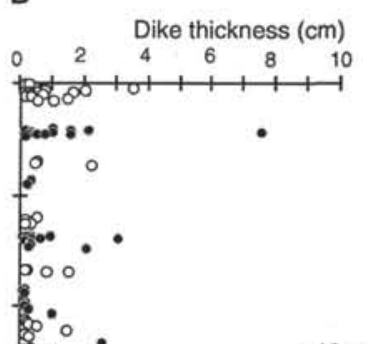

60

.
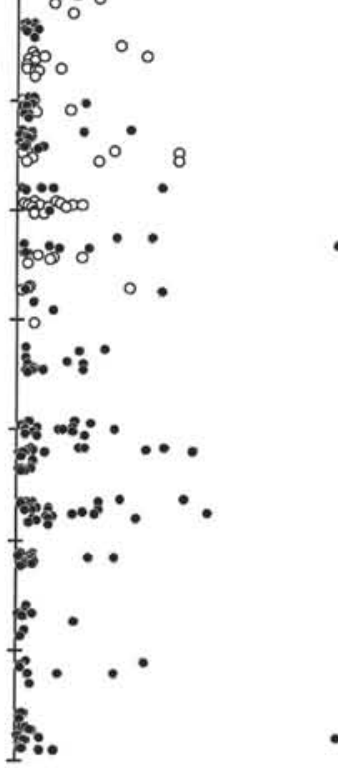

C

Number of dikes per meter of core

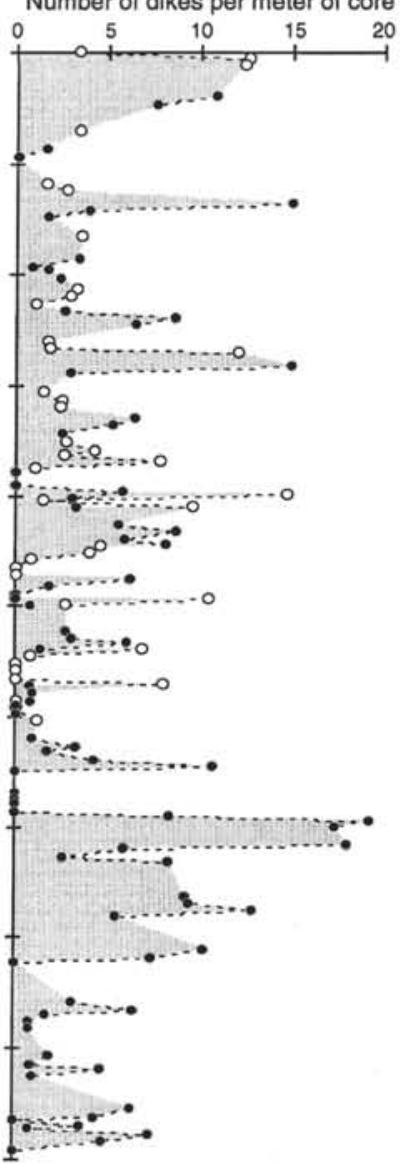

D

Dikes in each section of core (\%)

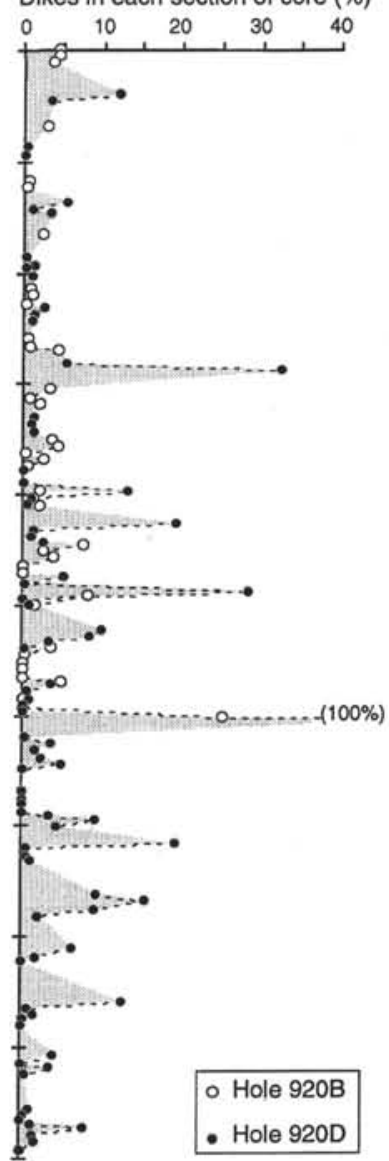

Figure 4. Downhole plots of thickness and abundance of gabbroic and altered dikelets in serpentinized peridotites from Site 920 . These plots are based on data listed in Table 1. Black boxes in A show the length of material that was recovered in each core. We have adopted the ODP convention of calculating the depth of provenance of any given piece of core by pushing all of the recovered material to the top of the corresponding cored interval. The "CPX lenses" column in A shows pieces of core that contain clinopyroxene-impregnation lenses (Fig. 3A). Shading in B, C, and D is based on putting together measurements made in Holes 920B and 920D, which are only $18 \mathrm{~m}$ apart.

and plagioclase is more extensively replaced by hydrous phases. Dikelets that still contain such relics are mineralogically and texturally diverse. They include zircon-bearing gabbro and gabbronorite (Figs. 3B, 5A), websterite (e.g., Figs. 3C, 5B), gabbronorite, olivine microgabbro (Fig. 5C), medium to coarse-grained apatite and/or oxide-bearing gabbro (fig. 7 in Shipboard Scientific Party, 1995), plagioclase and clinopyroxene-impregnation dikelets (Fig. 3D), coarsegrained isotropic gabbro, and one 5-cm-thick interval of clinopyroxene-bearing troctolite (Figs. 5D, 6).

There is no systematic downhole distribution of these diverse rock types (Table 2). There also do not appear to be specific dips and orientations associated with the different dikelet mineralogies. This last point, however, is based on a limited number of observations because extensive alteration prevents macroscopic determination of dikelet mineralogy, which therefore must be determined in thin section, which is only possible in the least altered samples. Dikelets rarely crosscut each other. In places where they do (e.g., Fig. 2; intervals 153-920D-18R-3, 45-60 cm, and 85-90 cm), they look more like conjugate sets of dikelets in thin section, but the extensive alteration makes it difficult to be certain.
All dikelets crosscut the coarse-grained, crystal-plastic fabric of the host ultramafic rocks. The only magmatic features in the core that are concordant with this fabric and have therefore probably formed before the dikelets are the clinopyroxene-impregnation lenses (Fig. $3 \mathrm{~A})$. In thin section, however, the clinopyroxene crystals that comprise these impregnation lenses are commonly undeformed (Ceuleneer and Cannat, this volume), an indication that they crystallized after the end of the main crystal-plastic deformation event in the ultramafic rocks. These impregnation lenses are mostly thin and discontinuous and are made only of interstitial clinopyroxene. In one of the three thicker impregnation lenses identified in the core (type 0 in Table 2), minute amounts of plagioclase are also associated with olivine in reaction rims between the lens clinopyroxene and aluminous spinel from the host peridotite (Fig. 5E).

Only four millimeter- to decimeter-thick intervals of crystal-plastic ultramafic mylonite (Figs. 3B, 5A) have been identified in the core recovered at Site 920 (Ceuleneer and Cannat, this volume). Three of these (intervals 153-920B-2R-1, 45-50 cm; 153-920D-2R-1, 125$145 \mathrm{~cm}$; and 153-920D-11R-3, 104-112 cm) contain zircon-bearing dikelets; the fourth (interval 153-920D-2R-2, 42-45 cm) contains al- 
Table 1. Downhole distribution of gabbroic rocks recovered as dikes and dikelets in Holes 920B and 920D.

\begin{tabular}{|c|c|c|c|c|c|c|}
\hline $\begin{array}{c}\text { Core, } \\
\text { section }\end{array}$ & $\begin{array}{c}\text { Depth } \\
\text { (mbsf) }\end{array}$ & $\begin{array}{l}\text { Length } \\
\text { (m) }\end{array}$ & $\underset{(\mathrm{m})}{\mathrm{A}}$ & $\begin{array}{c}\text { B } \\
(\%)\end{array}$ & C & D \\
\hline \multicolumn{7}{|l|}{$153-920 \mathrm{~B}-$} \\
\hline $1 W-1$ & 0.04 & 0.90 & 0.0380 & 4.25 & 3 & 3.35 \\
\hline $1 \mathrm{~W}-2$ & 1.27 & 1.28 & 0.0555 & 4.35 & 16 & 12.55 \\
\hline IW-3 & 2.24 & 0.97 & 0.0333 & 3.43 & 12 & 12.37 \\
\hline $2 \mathrm{R}-1$ & 14.05 & 0.91 & 0.0265 & 2.91 & 3 & 3.29 \\
\hline $3 \mathrm{R}-1$ & 23.68 & 1.31 & 0.0060 & 0.46 & 2 & 1.53 \\
\hline $3 R-2$ & 24.89 & 1.14 & 0.0040 & 0.35 & 3 & 2.64 \\
\hline $4 \mathrm{R}-1$ & 33.26 & 1.17 & 0.0255 & 2.19 & 4 & 3.43 \\
\hline $5 R-1$ & 42.82 & 1.26 & 0.0095 & 0.76 & 4 & 3.18 \\
\hline $5 R-2$ & 43.99 & 1.40 & 0.0150 & 1.07 & 4 & 2.86 \\
\hline $5 \mathrm{R}-3$ & 45.43 & 1.03 & 0.0020 & 0.19 & 1 & 0.97 \\
\hline $6 \mathrm{R}-1$ & 51.97 & 1.19 & 0.0065 & 0.55 & 2 & 1.68 \\
\hline $6 \mathrm{R}-2$ & 53.16 & 1.10 & 0.0080 & 0.73 & 2 & 1.82 \\
\hline $6 \mathrm{R}-3$ & 54.28 & 0.67 & 0.0290 & 4.34 & 8 & 11.98 \\
\hline $7 \mathrm{R}-1$ & 61.06 & 1.35 & 0.0430 & 3.18 & 2 & 1.48 \\
\hline $7 \mathrm{R}-2$ & 62.59 & 1.25 & 0.0110 & 0.88 & 3 & 2.41 \\
\hline $7 \mathrm{R}-3$ & 63.83 & 0.87 & 0.0170 & 1.97 & 2 & 2.31 \\
\hline $8 \mathrm{R}-1$ & 70.43 & 1.11 & 0.0400 & 3.60 & 3 & 2.70 \\
\hline $8 R-2$ & 71.68 & 1.19 & 0.0515 & 4.34 & 5 & 4.21 \\
\hline $8 \mathrm{R}-3$ & 72.83 & 1.20 & 0.0028 & 0.23 & 3 & 2.50 \\
\hline $8 R-4$ & 73.97 & 1.16 & 0.0292 & 2.51 & 9 & 7.73 \\
\hline $8 \mathrm{R}-5$ & 75.13 & 0.97 & 0.0050 & 0.51 & 1 & 1.03 \\
\hline $9 \mathrm{R}-1$ & 79.76 & 1.16 & 0.0235 & 2.03 & 17 & 14.67 \\
\hline $9 \mathrm{R}-2$ & 80.92 & 1.37 & 0.0160 & 1.17 & 2 & 1.46 \\
\hline $9 \mathrm{R}-3$ & 82.28 & 1.32 & 0.0085 & 2.02 & 4 & 9.52 \\
\hline $9 \mathrm{R}-4$ & 83.62 & 0.45 & 0.0000 & & & \\
\hline $10 \mathrm{R}-1$ & 89.17 & 1.17 & 0.0835 & 7.59 & 5 & 4.55 \\
\hline $10 \mathrm{R}-2$ & 90.50 & 1.26 & 0.0310 & 2.47 & 5 & 3.98 \\
\hline $10 \mathrm{R}-3$ & 91.62 & 1.34 & 0.0500 & 3.75 & 1 & 0.75 \\
\hline $10 \mathrm{R}-4$ & 93.17 & 1.30 & 0.0000 & 0.00 & & 0.00 \\
\hline 10R-5 & 94.35 & 0.51 & 0.0000 & 0.00 & & 0.00 \\
\hline $11 \mathrm{R}-1$ & 98.53 & 1.25 & 0.1020 & 8.19 & 13 & 10.44 \\
\hline $11 \mathrm{R}-2$ & 99.96 & 1.15 & 0.0180 & 1.57 & 3 & 2.61 \\
\hline $12 \mathrm{R}-1$ & 107.77 & 1.31 & 0.0470 & 3.58 & 9 & 6.85 \\
\hline $12 \mathrm{R}-2$ & 109.07 & 1.38 & 0.0030 & 0.22 & 1 & 0.73 \\
\hline $12 \mathrm{R}-3$ & 110.41 & 0.94 & 0.0000 & 0.00 & & 0.00 \\
\hline $12 R-4$ & 111.77 & 1.16 & 0.0000 & 0.00 & & 0.00 \\
\hline $12 \mathrm{R}-5$ & 113.33 & 1.30 & 0.0000 & 0.00 & & 0.00 \\
\hline $12 \mathrm{R}-6$ & 114.03 & 0.87 & 0.0425 & 4.89 & 7 & 8.05 \\
\hline $13 \mathrm{R}-1$ & 117.28 & 1.29 & 0.0000 & 0.00 & , & 0.00 \\
\hline $13 \mathrm{R}-2$ & 118.52 & 1.24 & 0.0000 & 0.00 & & 0.00 \\
\hline $13 R-3$ & 120.66 & 1.24 & 0.3090 & 24.94 & 2 & 1.07 \\
\hline $13 \mathrm{R}-4$ & 121.03 & 0.58 & 0.5800 & 100.00 & 1 & \\
\hline Total & & 46.95 & 1.77 & 3.89 & 160 & 3.58 \\
\hline \multicolumn{7}{|l|}{ 153-920D- } \\
\hline $2 \mathrm{R}-1$ & 8.04 & 1.305 & 0.1560 & 11.95 & 14 & 10.73 \\
\hline $2 \mathrm{R}-2$ & 9.35 & 0.4 & 0.0130 & 3.25 & 3 & 7.50 \\
\hline $3 R-1$ & 17.55 & 1.282 & 0.0045 & 0.35 & 2 & 1.56 \\
\hline $3 \mathrm{R}-2$ & 18.87 & 0.65 & 0.0000 & 0.00 & & 0.00 \\
\hline $4 \mathrm{R}-1$ & 27.32 & 1.073 & 0.0560 & 5.22 & 16 & 14.91 \\
\hline $4 \mathrm{R}-2$ & 28.45 & 1.04 & 0.0110 & 1.06 & 4 & 3.85 \\
\hline $4 \mathrm{R}-3$ & 29.47 & 0.595 & 0.0200 & 3.36 & i & 1.68 \\
\hline $5 \mathrm{R}-1$ & 36.94 & 0.91 & 0.0022 & 0.24 & 3 & 3.30 \\
\hline $5 \mathrm{R}-2$ & 38.79 & 1.315 & 0.0150 & 1.14 & 1 & 0.76 \\
\hline $5 \mathrm{R}-3$ & 39.21 & 1.23 & 0.0020 & 0.16 & 2 & 1.63 \\
\hline $5 \mathrm{R}-4$ & 40.53 & 1.27 & 0.0140 & 1.10 & 3 & 2.36 \\
\hline $6 \mathrm{R}-1$ & 46.52 & 1.174 & 0.0290 & 2.47 & 3 & 2.56 \\
\hline $6 \mathrm{R}-2$ & 47.73 & 1.047 & 0.0142 & 1.36 & 9 & 8.60 \\
\hline $6 \mathrm{R}-3$ & 48.78 & 0.93 & 0.0090 & 0.97 & 6 & 6.45 \\
\hline $7 \mathrm{R}-1$ & 56.27 & 1.213 & 0.0657 & 5.42 & 18 & 14.84 \\
\hline $7 \mathrm{R}-2$ & 57.48 & 1.018 & 0.3310 & 32.51 & $\begin{array}{r}10 \\
3\end{array}$ & $\begin{array}{l}14.95 \\
\end{array}$ \\
\hline $8 \mathrm{R}-1$ & 65.92 & 1.248 & 0.0165 & 1.32 & 8 & 6.41 \\
\hline $8 \mathrm{R}-2$ & 67.22 & 1.352 & 0.0125 & 0.92 & 7 & 5.18 \\
\hline $8 \mathrm{R}-3$ & 68.62 & 0.815 & 0.0050 & 1.20 & i & 1.23 \\
\hline 9R-1 & 75.68 & 1.025 & 0.0000 & 0.00 & & 0.00 \\
\hline $9 \mathrm{R}-2$ & 76.92 & 1.256 & 0.0000 & & & 0.00 \\
\hline $10 \mathrm{R}-1$ & 78.13 & 1.193 & 0.0000 & 0.00 & & 0.00 \\
\hline $10 \mathrm{R}-2$ & 79.44 & 1.364 & 0.1790 & 13.12 & 8 & 5.87 \\
\hline
\end{tabular}

tered dikelet material but no zircon. In every case, the dikelets are concordant with the mylonitic foliation, and magmatic minerals are dynamically recrystallized (Fig. 5A). Two mylonitic intervals (intervals $153-920 \mathrm{~B}-2 \mathrm{R}-1,45-50 \mathrm{~cm}$, and $153-920 \mathrm{D}-2 \mathrm{R}-1,125-145 \mathrm{~cm}$ ) also contain discordant patches of undeformed dikelet minerals, indicating that complete crystallization of the dikelets postdated mylonitization.

Other zircon-bearing dikelets (type 5 in Table 2) cut through coarse-grained ultramafic rocks. Their margins with the host ultramafic rocks are straight and altered into a chlorite, talc, and actinolite mesh. These dikelets are either undeformed, with a medium-grained, isotropic texture (recognizable only in the least altered samples), or dynamically recrystallized. The 81 -cm-thick gabbroic interval at the

\begin{tabular}{|c|c|c|c|c|c|c|}
\hline $\begin{array}{l}\text { Core, } \\
\text { section }\end{array}$ & $\begin{array}{l}\text { Depth } \\
\text { (mbsf) }\end{array}$ & $\begin{array}{l}\text { Length } \\
\text { (m) }\end{array}$ & $\underset{(\mathrm{m})}{\mathrm{A}}$ & $\begin{array}{c}\text { B } \\
(\%)\end{array}$ & C & D \\
\hline 10R-3 & 80.72 & 1.338 & 0.0120 & 0.90 & 4 & 2.99 \\
\hline $10 R-4$ & 82.03 & 1.225 & 0.0075 & 0.61 & 4 & 3.27 \\
\hline $11 \mathrm{R}-1$ & 85.37 & 1.251 & 0.2417 & 19.32 & 7 & 5.60 \\
\hline $11 \mathrm{R}-2$ & 86.66 & 1.045 & 0.0130 & 1.24 & 9 & 8.61 \\
\hline $11 \mathrm{R}-3$ & 87.88 & 1.195 & 0.0130 & 1.09 & 7 & 5.86 \\
\hline $11 R-4$ & 89.04 & 0.245 & 0.0060 & 2.45 & 2 & 8.16 \\
\hline $12 \mathrm{R}-1$ & 95.11 & 1.285 & 0.0640 & 4.98 & 8 & 6.23 \\
\hline $12 \mathrm{R}-2$ & 96.34 & 1.093 & 0.0020 & 0.18 & 2 & 1.83 \\
\hline $12 \mathrm{R}-3$ & 97.85 & 1.22 & 0.3450 & 28.28 & 1 & 0.82 \\
\hline $12 \mathrm{R}-4$ & 98.83 & 1.345 & 0.0000 & 0.00 & & 0.00 \\
\hline $12 \mathrm{R}-5$ & 100.01 & 1.275 & 0.0100 & 0.78 & 1 & 0.78 \\
\hline $13 \mathrm{R}-1$ & 104.69 & 0.746 & 0.0730 & 9.79 & 2 & 2.68 \\
\hline $13 \mathrm{R}-2$ & 105.99 & 1.328 & 0.1115 & 8.40 & 4 & 3.01 \\
\hline $13 \mathrm{R}-3$ & 106.71 & 1.173 & 0.0394 & 3.36 & 7 & 5.97 \\
\hline $13 R-4$ & 107.93 & 0.731 & 0.0020 & 0.27 & 1 & 1.37 \\
\hline $14 \mathrm{R}-1$ & 114.35 & 1.305 & 0.0470 & 3.60 & 2 & 1.53 \\
\hline $14 \mathrm{R}-2$ & 115.68 & 1.17 & 0.0050 & 0.43 & 1 & 0.85 \\
\hline $14 \mathrm{R}-3$ & 117.11 & 1.36 & 0.0110 & 0.81 & 1 & 0.74 \\
\hline $14 \mathrm{R}-4$ & 118.19 & 1.33 & 0.0000 & 0.00 & & 0.00 \\
\hline $14 \mathrm{R}-5$ & 119.55 & 1.29 & 0.0000 & 0.00 & & 0.00 \\
\hline $15 \mathrm{R}-1$ & 124.10 & 1.126 & 0.0020 & 0.18 & 1 & 0.89 \\
\hline $15 \mathrm{R}-2$ & 125.38 & 1.26 & 0.0460 & 3.65 & 4 & 3.17 \\
\hline $15 \mathrm{R}-3$ & 126.38 & 1.165 & 0.0170 & 1.46 & 2 & 1.72 \\
\hline $15 R-4$ & 127.86 & 1.185 & 0.0280 & 2.36 & 5 & 4.22 \\
\hline $15 \mathrm{R}-5$ & 128.94 & 1.028 & 0.0495 & 4.82 & 11 & 10.70 \\
\hline $15 \mathrm{R}-6$ & 129.78 & 1.155 & 0.0000 & 0.00 & & 0.00 \\
\hline $16 \mathrm{R}-1$ & 133.81 & 1.255 & 0.0000 & 0.00 & & 0.00 \\
\hline $16 \mathrm{R}-2$ & 135.07 & 1.017 & 0.0000 & 0.00 & & 0.00 \\
\hline $16 \mathrm{R}-3$ & 136.02 & 0.989 & 0.0000 & 0.00 & & 0.00 \\
\hline $16 R-4$ & 137.51 & 1.115 & 0.0000 & 0.00 & & 0.00 \\
\hline $16 R-5$ & 138.26 & 1.32 & 0.0440 & 3.33 & 11 & 8.33 \\
\hline $16 \mathrm{R}-6$ & 139.16 & 1.146 & 0.1044 & 9.11 & 22 & 19.20 \\
\hline 16R-7 & 140.28 & 0.806 & 0.0340 & 4.22 & 14 & 17.37 \\
\hline $17 \mathrm{R}-1$ & 143.27 & $\begin{array}{l}1.057 \\
1.057\end{array}$ & 0.2030 & 19.21 & 20 & 18.92 \\
\hline $17 \mathrm{R}-2$ & 144.12 & 0.852 & 0.0045 & 0.53 & 5 & 5.87 \\
\hline $17 \mathrm{R}-3$ & 145.52 & 1.19 & 0.0050 & 0.42 & 3 & 2.52 \\
\hline $17 \mathrm{R}-4$ & 146.64 & 1.315 & 0.0135 & 1.03 & 11 & 8.37 \\
\hline $18 \mathrm{R}-1$ & 152.69 & 1.3 & 0.1230 & 9.46 & 12 & 9.23 \\
\hline $18 \mathrm{R}-2$ & 153.94 & 1.055 & 0.1620 & 15.36 & 11 & 10.43 \\
\hline 18R-3 & 155.32 & 1.237 & 0.1130 & 9.14 & 16 & 12.93 \\
\hline $18 \mathrm{R}-4$ & 156.53 & 0.915 & 0.0195 & 2.13 & 5 & 5.46 \\
\hline $19 \mathrm{R}-1$ & 162.34 & 1.175 & 0.0757 & 6.44 & 12 & 10.21 \\
\hline 19R-2 & 163.80 & 1.206 & 0.0205 & 1.70 & 9 & 7.46 \\
\hline $19 \mathrm{R}-3$ & 164.81 & 0.392 & 0.0000 & 0.00 & & 0.00 \\
\hline $20 \mathrm{R}-1$ & 171.94 & 0.971 & 0.1230 & 12.67 & 4 & 4.12 \\
\hline $20 \mathrm{R}-2$ & 173.18 & 0.924 & 0.0072 & 0.78 & 6 & 6.49 \\
\hline $20 \mathrm{R}-3$ & 174.21 & 1.237 & 0.0180 & 1.46 & 2 & 1.62 \\
\hline $20 \mathrm{R}-4$ & 175.21 & 1.288 & 0.0020 & 0.16 & 1 & 0.78 \\
\hline 20R-5 & 176.42 & 1.355 & 0.0010 & 0.07 & I & 0.74 \\
\hline $21 \mathrm{R}-1$ & 181.52 & 1.055 & 0.0440 & 4.17 & 3 & 2.84 \\
\hline $21 \mathrm{R}-2$ & 183.03 & 1.2 & 0.0010 & 0.08 & $i$ & 0.83 \\
\hline $21 \mathrm{R}-3$ & 184.02 & 1.295 & 0.0465 & 3.59 & 6 & 4.63 \\
\hline $21 R-4$ & 185.25 & 1.025 & 0.0040 & 0.39 & 1 & 0.98 \\
\hline $22 \mathrm{R}-1$ & 191.29 & 0.472 & 0.0042 & 0.89 & 3 & 6.36 \\
\hline $22 \mathrm{R}-2$ & 192.59 & 0.92 & 0.0012 & 0.13 & 4 & 4.35 \\
\hline $22 \mathrm{R}-3$ & 193.25 & 0.66 & 0.0000 & 0.00 & & 0.00 \\
\hline $22 R-4$ & 194.08 & 1.132 & 0.0135 & 1.19 & 4 & 3.53 \\
\hline $22 \mathrm{R}-5$ & 194.86 & 1.292 & 0.1025 & 7.93 & 2 & 1.55 \\
\hline $22 \mathrm{R}-6$ & 195.79 & $\begin{array}{l}1.099 \\
1.092\end{array}$ & 0.0160 & 1.46 & 8 & 7.28 \\
\hline $22 \mathrm{R}-7$ & 197.05 & 1.259 & 0.0214 & 1.70 & 6 & 4.77 \\
\hline $22 \mathrm{R}-8$ & 198.73 & 0.7 & 0.0000 & 0.00 & & 0.00 \\
\hline Total & & 91.8 & 3.4288 & 3.74 & 401 & 4.37 \\
\hline
\end{tabular}

Notes: $\mathrm{A}=$ cumulative thickness of gabbroic rocks in each section of core. $\mathrm{B}=$ percentage of gabbroic rocks in each section of core. $\mathrm{C}=$ number of gabbroic dikes and dikelets in each section of core. $\mathrm{D}=$ number of gabbroic dikes and dikelets per meter in each section of core. Data in B and D are plotted in Figure 4.

base of Hole 920B contains one piece of mylonitized olivine and zircon-bearing gabbronorite (Sample 153-920B-13R-3, 134-139 cm; Table 2). All other zircon-bearing dikelets identified in the core are thinner than $2 \mathrm{~cm}$ (Table 2).

Dikelets classified as types 3 and 4 in Table 2 contain accessory minerals such as apatite, brown amphibole, or ilmenite. The modal abundance of these accessory minerals is variable: from less than $1 \%$ in most samples, up to $12.5 \%$ poikilitic brown amphibole in the olivine microgabbro of intervals $153-920 \mathrm{~B}-13 \mathrm{R}-4,0-80 \mathrm{~cm}$, and $153-$ 920D-7R-2, 11-37 cm (point counting of 3070 points) and up to $3 \%$ euhedral apatite in Sample 153-920D-2R-1, 104-106 cm (point counting of 3034 points). The distinction between type 3 and type 4 is based on the presence (type 4) or absence (type 3 ) of orthopyrox- 

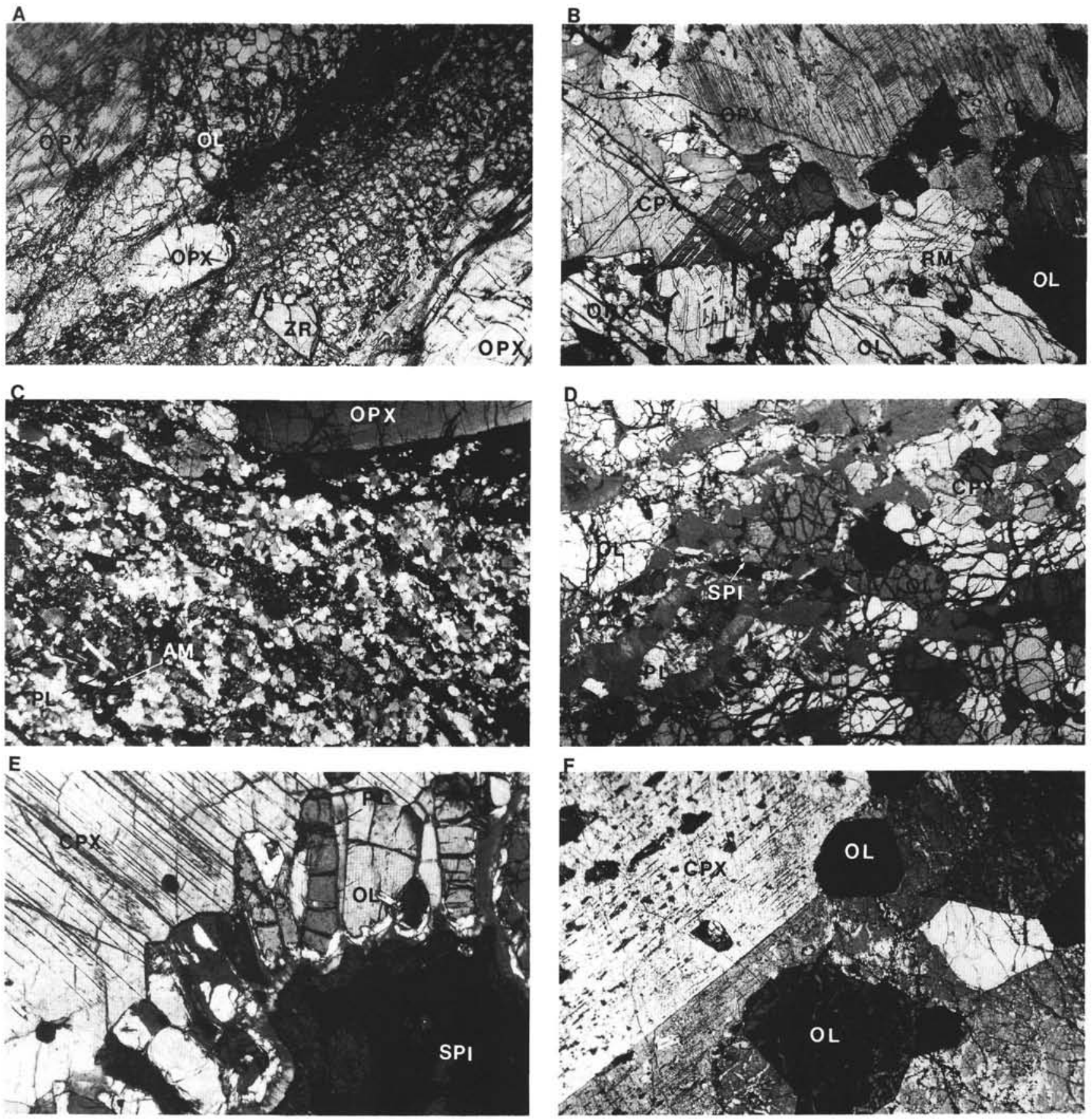

Figure 5. Photomicrographs of Site 920 magmatic intervals. Crossed nicols except in A. Abbreviations: $\mathrm{OL}=$ olivine; $\mathrm{PL}=\mathrm{plagioclase} ; \mathrm{OPX}=\mathrm{orthopyroxene} ;$ $\mathrm{CPX}=$ clinopyroxene; $\mathrm{SPI}=$ spinel; $\mathrm{AM}=$ brown hornblende; $\mathrm{OX}=$ iron-titanium oxide; $\mathrm{ZR}=$ zircon. $\mathrm{A}$. Interval $153-920 \mathrm{D}-2 \mathrm{R}-1,126-132 \mathrm{~cm}$. Finely recrystallized, zircon-bearing dikelet in mylonitic harzburgite (core photograph in Fig. 3B). Recrystallized assemblage in dikelet includes plagioclase, clinopyroxene, orthopyroxene, and brown amphibole. Large euhedral zircon is also marginally granulated along its grain boundaries. Rounded orthopyroxene porphyroclast and recrystallized olivine belong to the host harzburgite. Length of view is $3.2 \mathrm{~mm}$. B. Interval 153-920B-11R-1, 100-108 cm. Contact between pyroxenite dikelet and serpentinized harzburgite (lower right corner). Dikelet contains large clinopyroxene crystals, smaller orthopyroxene grains, amphibole, and iron-titanium oxides. Olivine from the harzburgite has lobate contacts with minerals from the dikelet. Length of view is $3.2 \mathrm{~mm}$. C. Interval 153-920B-13R-4, 45-50 $\mathrm{cm}$. Contact between coarse-grained oxide gabbronorite and olivine microgabbro in the thick gabbroic interval at the base of Hole $920 \mathrm{~B}$. Both lithologies are foliated and dynamically recrystallized. Foliation in olivine microgabbro (dips to the right in photograph) is oblique to foliation in gabbronorite (subhorizontal in photograph). Olivine microgabbro contains abundant brown hornblende. In domains that have not recrystallized, this brown hornblende is poikilitic and encloses small plagioclase laths. Length of view is $8 \mathrm{~mm}$. D. Interval 153-920D-11R-1, 40-49 cm. Clinopyroxene-bearing troctolite (core sketch in Fig. 6). Olivine is equant and polygonal. Spinel is elongated and outlines a foliation (subhorizontal in photograph). Clinopyroxene is interstitial. Plagioclase is largely altered and also interstitial (altered plagioclase is a dull gray in photograph). Length of view is $3.2 \mathrm{~mm}$. E. Interval 153-920B-8R-5, 108-114 cm. Clinopyroxene in impregnation lens reacted with spinel from the host harzburgite to form plagioclase, olivine, and chromian spinel. Grayish material around spinel grain is altered plagioclase. Length of view is $0.8 \mathrm{~mm}$. F. Interval 153-920D-18R-3, 48-50 cm. Contact between large clinopyroxene from apatite-bearing gabbro dikelet and polygonal olivine from the host harzburgite. Length of view is $3.2 \mathrm{~mm}$. 


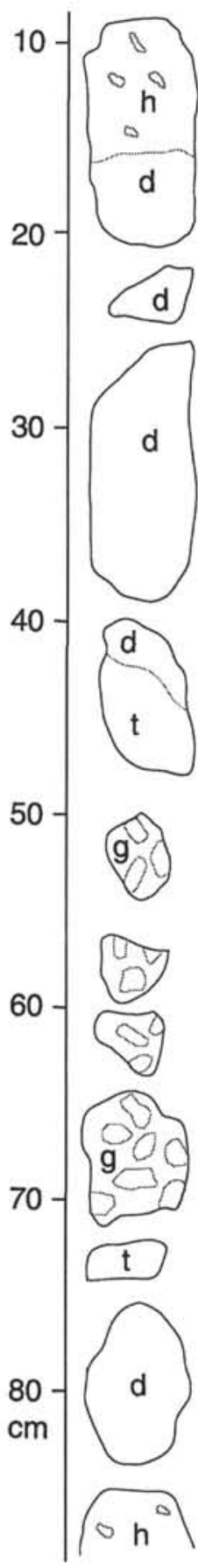

Figure 6. Sketch of interval 153-920D-11R-1, 8-88 cm: coarse-grained gabbro $(\mathrm{g} ; 50-72 \mathrm{~cm})$; clinopyroxene-bearing troctolite $(\mathrm{t} ; 42-48 \mathrm{~cm}$, and possibly also $72-74 \mathrm{~cm}$; photomicrograph in Fig. 5D); serpentinized dunite (d; $16-42 \mathrm{~cm}$ and $76-85 \mathrm{~cm})$; and serpentinized, pyroxene-poor harzburgite $(\mathrm{h}$; upward from $16 \mathrm{~cm}$, and downward from $85 \mathrm{~cm}$ ).

ene. Many type 3 samples come from thick gabbroic intervals (Table 2 ) and contain (or have contained if extensively altered) significant amounts of plagioclase. By contrast, many type 4 samples are centimeter-thick websterite dikelets.

With the exception of two intervals of olivine-bearing microgabbro (intervals 153-920B-13R-4, 0-80 cm, and 153-920D-7R-2, 11-
$37 \mathrm{~cm}$ ), type 3 and 4 dikelets are medium- to coarse-grained, with euhedral pyroxene grains (Figs. 3C, 5B). Most of these dikelets are undeformed or present only limited dynamic recrystallization of magmatic minerals along grain boundaries. Extensive dynamic recrystallization affects only the thick interval of olivine microgabbro and oxide gabbronorite in Section 153-920B-13R-3 (Fig. 5C). When preserved in the core, the margins of these dikelets show either syntaxial growth of dikelet clinopyroxene on pyroxene from the host peridotite (e.g., Sample 153-920B-11R-1, 100-108 cm) or, more commonly, dikelet minerals that have clean, $120^{\circ}$, grain boundaries with minerals from the host peridotite (Fig. 5F) and interstitial brown amphibole, clinopyroxene, and plagioclase impregnating the peridotite, up to $3 \mathrm{~cm}$ away from the dikelet margin.

Dikelets classified as type 2 in Table 2 contain undeformed clinopyroxene and plagioclase. The thickest interval of this rock type (Fig. 6) is a coarse-grained gabbro with poikilitic clinopyroxene. The other intervals are thinner, irregular dikelets and impregnations of interstitial plagioclase and clinopyroxene (Fig. 3D).

Finally, type 1 corresponds to an interval of clinopyroxene-bearing troctolite (Fig. 5D) that occurs in Section 153-920D-11R-1 (Fig. 6) just above the coarse-grained type 2 gabbro. It is in contact with extensively serpentinized dunite. A small piece of altered material that may also have been troctolitic (Fig. 6) is found under the gabbro and serpentinized dunite is found again underneath. The clinopyroxene-bearing troctolite is fine grained, and contains polygonal, strainfree olivine grains, elongated spinels that outline a weak foliation, interstitial clinopyroxene, and plagioclase (Fig. 5D). It has a faint modal layering that is defined by variations in the abundance of clinopyroxene and plagioclase and is parallel to slightly oblique to the spinel foliation.

\section{Mineral Composition}

Microprobe analyses were performed on the CAMEBAX "CAMPARIS" probes (Université de Paris VI), using a 20- to 40-nA beam, $15-\mathrm{kV}$ tension, and counting times of 10 to $80 \mathrm{~s}$. The beam was defocused for plagioclase.

The range of major-element compositional variations among magmatic rocks that intrude the ultramafic rocks at Site 920 is similar to that observed in gabbroic rocks from Hole 735B (ODP Leg 118; Southwest Indian Ridge; Ozawa et al., 1991): anorthite content of plagioclase ranges from $30 \%$ to $90 \%, \mathrm{Mg} \#\left(\mathrm{Mg} /\left[\mathrm{Mg}+\mathrm{Fe}_{\text {tot }}\right]\right)$ from $55 \%$ to $93 \%$ in clinopyroxene, $50 \%$ to $87 \%$ in olivine, and $50 \%$ to $83 \%$ in orthopyroxene (Table 2). Magmatic samples that contain both plagioclase and clinopyroxene relics mostly come from the thicker gabbroic intervals. In Figure 7, most of these samples plot on the same magmatic differentiation trend as the Southwest Indian Ridge, Hole 735B gabbroic rocks. The thinner type 3 dikelet in Sample 153920D-18R-3, 48-50 cm, however, plots off this trend toward higher clinopyroxene $\mathrm{Mg \#}$ values, and plagioclase in the deformed olivine microgabbro (type 4) of Sample 153-920B-13R-4, 45-50 cm (Fig. $5 C$ ), and in the websterite (type 4) of Sample 153-920D-13R-2, 132$134 \mathrm{~cm}$, has a wide range of anorthite content (Table 2).

Type 0,1 , and 2 magmatic rocks, which do not contain incompatible-element-rich minerals (apatite, ilmenite, amphibole, or zircon), accordingly plot at the least-differentiated end of the anorthite in plagioclase/Mg\# in clinopyroxene plot (Fig. 7). Thin clinopyroxene-impregnation lenses (type 0; Fig. 3A) do not contain plagioclase, and have clinopyroxene major-element compositions identical to those of residual clinopyroxene grains and exsolution lamellae in the host serpentinized peridotite. The thicker clinopyroxene lens of Sample 153920B-8R-5, 108-114 cm, contains plagioclase and clinopyroxene

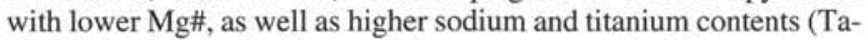
ble 3). Plagioclase in this sample is not comagmatic with the clinopyroxene, but is a product of a subsolidus reaction between the lens clinopyroxene and residual aluminous spinel from the peridotite (Fig. 
Table 2. Igneous mineralogy, thickness, and average mineral composition of gabbroic dikes and dikelets from Site 920.

\begin{tabular}{|c|c|c|c|c|c|c|c|c|c|c|c|c|c|c|c|}
\hline \multirow[b]{2}{*}{$\begin{array}{l}\text { Core, section, } \\
\text { interval }(\mathrm{cm})\end{array}$} & \multirow[b]{2}{*}{ Igneous mineralogy } & \multirow[b]{2}{*}{ Type } & \multirow[b]{2}{*}{$\begin{array}{l}\text { Thickness } \\
(\mathrm{cm})\end{array}$} & \multicolumn{4}{|c|}{ Average mineral composition } & \multicolumn{8}{|c|}{ Number of analyses and range of composition } \\
\hline & & & & Mg\# cpx & An\% $\mathrm{pl}$ & Mg\# opx & $\mathrm{Mg} \#$ ol & & $\mathrm{Mg} \# \mathrm{cpx}$ & & An\% pl & & Mg\# opx & & Mg\# ol \\
\hline 153-920B- & & & & & & & & & & & & & & & \\
\hline IW-2, 55-63 & $\mathrm{cpx},(\mathrm{pl}), \mathrm{am}, \mathrm{zr}, \mathrm{ox}, \mathrm{ap}$ & 5 & 2 & 76.65 & & & & 7 & $72.54-80.78$ & & & & & & \\
\hline IW $-3,100-108$ & $\mathrm{cpx},(\mathrm{pl}), \mathrm{zr}$ & 5 & 0.5 & 83.35 & & & & 4 & $80.89-84.92$ & & & & & & \\
\hline $\begin{array}{l}2 \mathrm{R}-1,47-50 \\
2 \mathrm{R}-1,94-100\end{array}$ & $\begin{array}{l}\text { altered, } \mathrm{zr} \\
\operatorname{cpx}, \mathrm{opx},(\mathrm{pl}), \mathrm{am}, \mathrm{ox}, \mathrm{ap}\end{array}$ & $\begin{array}{l}5 \\
4\end{array}$ & $\begin{array}{l}0.4 \\
2.2\end{array}$ & 83.23 & 55.93 & 78.89 & & 1 & & 4 & $48.07-66.82$ & 2 & $77.95-79.83$ & & \\
\hline $5 \mathrm{R}-1,58-62$ & cpx, (pl), ap & $\begin{array}{l}4 \\
3\end{array}$ & 0.2 & 75.17 & & & & 3 & $73.06-77.12$ & & & & & & \\
\hline 6R-3, 48-56 & altered, $\mathrm{zr}$ & 5 & & & & & & & & & & & & & \\
\hline $8 R-5,108-114$ & cpx & 0 & 0.5 & 90.38 & 76.58 & & & 6 & $89.18-91.2$ & 2 & $74.72-78.45$ & & & & \\
\hline $10 \mathrm{R}-3,0-9$ & cpx, (pl) & 2 & 5 & 89.036 & & & & 10 & $87.31-92.74$ & & & & & & \\
\hline $11 \mathrm{R}-1,0-5$ & cpx, zr & 5 & 1.2 & 80.45 & & & & 1 & & & & & & & \\
\hline $11 R-1,100-108$ & cpx, opx, (pl), am, ap & 4 & 2 & 66.79 & & 52.18 & & 3 & $64-70.73$ & & & 1 & & & \\
\hline $11 \mathrm{R}-1,110-119$ & срх,opx, (pl), am & 4 & 0.9 & 82.95 & & 81.17 & & 3 & $79.76-84.84$ & & & 2 & $79.05-83.29$ & & \\
\hline IIR-1, $131-140$ & altered & ? & 1.5 & & & & & & & & & & & & \\
\hline $11 \mathrm{R}-2,118-127$ & $\mathrm{cpx}, \mathrm{opx},(\mathrm{pl}), \mathrm{am}, \mathrm{ox}$ & 4 & 0.8 & 83.59 & & 80.34 & & 3 & $82.52-85.12$ & & & 4 & $79.92-81.01$ & & \\
\hline $13 R-3,113-117$ & cpx, (pl), ox & 3 & 0.0 & 70.3 & & 00.047 & & 2 & $68.52-72.08$ & & & 4 & $19.32-01.01$ & & \\
\hline $13 \mathrm{R}-3,134-139$ & cpx, opx, ol, pl, zr & 5 & 81 & 59.2 & 32.37 & 50.5 & 50.54 & 4 & $58.33-59.68$ & 1 & & 2 & $50.43-50.58$ & 3 & $50.19-50.91$ \\
\hline $13 \mathrm{R}-4,45-50$ & cpx, opx, pl, ox & 4 & & 59.52 & 30.31 & 52.12 & & 4 & $56.48-62.65$ & 2 & $30.19-30.43$ & 2 & $51.33-52.9$ & & \\
\hline $13 R-4,45-50$ & ol, cpx, opx, pl, am & 4 & & 72.1 & 50.86 & 60.16 & 62.28 & 4 & $69.16-74.18$ & 7 & $* 36.43-62.18$ & 2 & $58.32-61.99$ & 4 & $58.63-63.57$ \\
\hline $153-920 \mathrm{D}-$ & & & & & & & & & & & & & & & \\
\hline $2 \mathrm{R}-1,104-106$ & $\mathrm{cpx}, \mathrm{pl}$,ap, ox, am & 3 & 7.5 & 66.51 & 40.65 & & & 9 & $63.98-69.81$ & 2 & $* 39.7-41.5$ & & & & \\
\hline $2 \mathrm{R}-1,126-132$ & cpx, opx, (pl), zr, ap, am & 5 & 0.2 & 67.81 & & 63.36 & & 4 & $67.51-68.2$ & & & 3 & $59.58-63.91$ & & \\
\hline $2 \mathrm{R}-2,39-47$ & altered & ? & 0.1 & & & & & & & & & & & & \\
\hline $4 \mathrm{R}-2,9-13$ & $(\mathrm{pl})$ & 2 & 2 & & & & & & & & & & & & \\
\hline $7 \mathrm{R}-1,76-83$ & altered, am & ? & 0.25 & & & & & & & & & & & & \\
\hline $7 R-2,33-36$ & ol, cpx, pl, am & 3 & 33 & 75.9 & 55.64 & & 61.36 & 4 & $75.53-76.09$ & 3 & $53.32-58.21$ & & & 4 & $60.31-64.18$ \\
\hline $10 \mathrm{R}-2,48-52$ & altered, ap & ? & 0.5 & & & & & & & & & & & & \\
\hline 11R-1, 45-49 & ol, cpx, pl, spi & $\mathrm{i}$ & 3.5 & 89.68 & 85.946 & & 86.48 & 5 & $89.18-90.1$ & 3 & $85.69-86.44$ & & & 7 & $86.14-86.82$ \\
\hline IIR-1, $60-64$ & $\mathrm{cpx}, \mathrm{pl}$ & 2 & 18 & 87.17 & 86.46 & & & 7 & $85.42-88.78$ & 7 & $85.08-89.7$ & & & & \\
\hline 11R-3, 104-108 & cpx, (pl), zr & 5 & 0.4 & 86.45 & & & & 3 & $85.96-87.15$ & & & & & & \\
\hline $11 \mathrm{R}-4,4-9$ & altered & $\stackrel{?}{?}$ & 0.6 & & & & & & & & & & & & \\
\hline $12 \mathrm{R}-3,82-86$ & $\mathrm{pl}$ & 2 & 0.2 & & & & & & & & & & & & \\
\hline $12 \mathrm{R}-3,117-120$ & cpx, pl, ap, ox & 3 & 35 & 57.56 & 31.08 & & & 4 & $55.9-58.2$ & 2 & $30.59-31.57$ & & & & \\
\hline $13 \mathrm{R}-1,71-76$ & cpx, opx, pl, am, ox & 4 & 4.2 & 73.29 & & 72.32 & & 4 & $71.81-74.55$ & & & 1 & & & \\
\hline $13 R-2,132-134$ & cpx, opx, pl, am, ox & 4 & 10 & 70.96 & 48.4 & 66.11 & & 6 & $68.44-72.21$ & 2 & $41.88-54.92$ & 1 & & & \\
\hline $13 \mathrm{R}-2,136-143$ & cpx, opx, (pl), am, ox & 4 & & 75.44 & & 71.86 & & 3 & $74.12-77.29$ & & & 2 & & & \\
\hline $14 \mathrm{R}-2,114-120$ & $\mathrm{cpx}, \mathrm{pl}$ & 2 & 0.5 & 92.647 & 84.274 & & & 1 & & 4 & $83.17-85.26$ & & & & \\
\hline $16 \mathrm{R}-6,126-132$ & altered & ? & 0.2 & & & & & & & & & & & & \\
\hline $18 \mathrm{R}-1,10-16$ & altered & ? & 0.6 & & & & & & & & & & & & \\
\hline $18 \mathrm{R}-1,38-44$ & altered & ? & 0.5 & & & & & & & & & & & & \\
\hline $18 \mathrm{R}-2,103-106$ & cpx, pl, am, ox & 3 & 4.5 & 72.73 & 44.34 & & & 3 & $71.93-73.26$ & 2 & $43.97-44.71$ & & & & \\
\hline $18 \mathrm{R}-2,108-113$ & $\mathrm{cpx},(\mathrm{pl}), \mathrm{am}$ & 3 & 2.5 & 88.94 & & & & 3 & $88.45-89.39$ & & & & & & \\
\hline $18 \mathrm{R}-3,48-50$ & cpx, pl, am, ox, ap & 3 & 0.5 & 87.14 & 57.52 & & & 4 & $84.37-89.39$ & 4 & $53.05-62.85$ & & & & \\
\hline $18 \mathrm{R}-3,88-93$ & cpx, (pl), am & 3 & 0.5 & 88.52 & & & & 9 & $87.02-89.39$ & & & & & & \\
\hline $18 \mathrm{R}-3,122-127$ & cpx, opx, (pl), am & 4 & 3.7 & 78.75 & & 72.85 & & 2 & $77.38-80.132$ & & & 2 & $72.24-73.47$ & & \\
\hline $22 \mathrm{R}-4,110-115$ & altered, zr, ap & 5 & 0.4 & & & & & & & & & & & & \\
\hline $22 \mathrm{R}-5,132-141$ & cpx, opx, (pl), am & 4 & 4 & 75.99 & & 74.92 & & 2 & $75.45-76.55$ & & & 2 & & & \\
\hline
\end{tabular}

Notes: Selected microprobe analyses are listed in Table 3. Type $=$ lithologic type defined in text; $0=$ altered; ol $=$ olivine; $p l=$ plagioclase; opx $=$ orthopyroxene; $c p x=$ clinopyroxene; spi $=$ spinel; am $=$ brown hornblende; ox $=$ iron-titanium oxide; $z r=$ zircon; ap = apatite. Plagioclase An contents marked by an asterisk have been measured on recrystallized grains. 

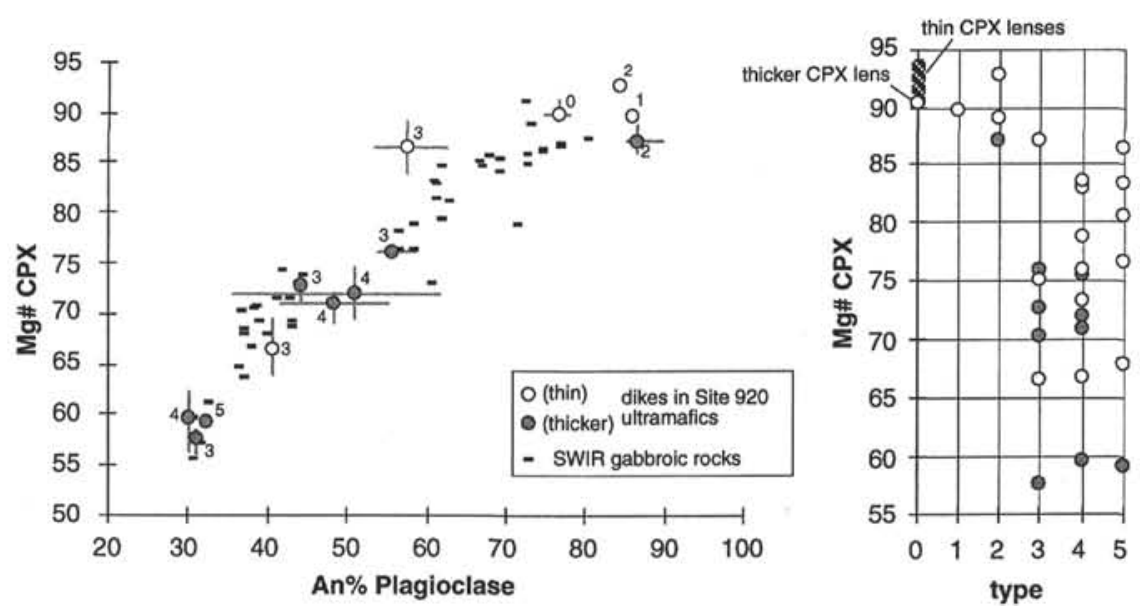

Figure 7. Average Mg\# and anorthite content of clinopyroxene (CPX) and plagioclase in gabbroic dikes and dikelets from Site 920 . Numbers beside each point refer to the lithologic types listed in Table 2. Plotted values and ranges of variation are also listed in Table 2. Southwest Indian Ridge (SWIR) gabbroic rocks come from Site 735 (Ozawa et al., 1991) and from other ridge and transform fault locations (Meyer et al., 1989). The plot of clinopyroxene Mg\# as a function of type refers to the lithologic types listed in Table 2 (and discussed in the text). This plot also includes dikelets that do not contain fresh plagioclase and cannot therefore be shown on the $\mathrm{Mg \# /An \%} \mathrm{diagram.}$

5E). Clinopyroxene and plagioclase in the clinopyroxene-bearing troctolite of Sample 153-920D-11R-1, 40-49 cm, and in the nearby gabbro (Sample 153-920D-11R-1, 60-64 cm) have similar compositions (Fig. 7; Table 2). Clinopyroxene chromium content is, however, higher in the clinopyroxene-bearing troctolite (Table 3 ).

Magmatic rocks that do contain incompatible-element-rich minerals (apatite, ilmenite, amphibole, or zircon) have a very wide range of mineral major-element compositions, particularly of $\mathrm{Mg \#}$ in ironmagnesium silicates (Table 2; Fig. 7). Mg\# values as high as $87 \%$ are measured in clinopyroxene porphyroclasts from the zircon-bearing mylonitic dikelet in Sample 153-920D-11R-3, 104-108 cm. Furthermore, the apatite-, ilmenite-, and amphibole-bearing dikelet in Sample 153-920D-18R-3, 48-50 cm (Fig. 2) contains clinopyroxene with $\mathrm{Mg}$ \# values up to $89 \%$ (Table 2). This range is narrower if only the thick gabbroic intervals are considered (Fig. 7): clinopyroxene $\mathrm{Mg} \#$ values do not exceed $76 \%$ in thick type 3 and 4 intervals, and $59.7 \%$ in the only identified thick zircon-bearing (type 5) interval (Sample 153-920B-13R-3, 134-139 cm; Table 2).

Similarly, interstitial brown amphibole has $\mathrm{Mg \#}$ values of less than $70 \%$ in thick gabbroic intervals (Fig. 8), and as high as $85 \%$ in and near centimeter-thick dikelets. Titanium and $\mathrm{Na}+\mathrm{K}$ contents are similar in the two groups of amphiboles, but $\mathrm{Cr}_{2} \mathrm{O}_{3}$ content is higher in amphiboles from thin dikelets. $\mathrm{Mg} \#$ values and $\mathrm{Al}^{\mathrm{IV}}, \mathrm{Na}+\mathrm{K}$, titanium, and chromium contents in brown amphiboles from thick gabbroic intervals are positively correlated with $\mathrm{Mg \#}$ values in neighboring clinopyroxene (Fig. 8). This correlation is weaker, but also holds for brown amphiboles in and near thin dikelets, but these amphiboles have higher $\mathrm{Mg \#}$ and $\mathrm{Cr}_{2} \mathrm{O}_{3}$ contents, and lower $\mathrm{Al}^{\mathrm{IV}}$ content (maximum 1.8 in a dikelet with a $\mathrm{Mg} \#$ of $87 \%$ in clinopyroxene, vs. a maximum of 1.9 in a thick gabbroic interval with a $\mathrm{Mg} \#$ of $75.9 \%$ in clinopyroxene; Table 3 ).

Figure 9 shows the sodium, titanium, and chromium contents of individual clinopyroxene grains from the different types of magmatic rocks that intruded the Site 920 serpentinized peridotites, vs. their $\mathrm{Mg} \#$ values. The difference in the range of $\mathrm{Mg} \#$ values between thick gabbroic intervals and thin dikelets is again apparent. Sodium content is slightly lower than average in high- $\mathrm{Mg} \#$ clinopyroxenes from type 2 gabbros and impregnating dikelets, in the clinopyroxene-bearing troctolite, and in the clinopyroxene lens of Sample 153-920B-8R-5, $108-114 \mathrm{~cm}$. These grains also have high chromium content and low to moderate titanium content. By contrast, high-Mg\# clinopyroxenes from thin type 3 and 4 dikelets commonly have high to very high titanium content. Among these clinopyroxenes, those with the highest $\mathrm{Mg} \#$ values are found as interstitial crystals, associated with brown amphibole and plagioclase, within the host ultramafic rocks near the dikelet margins. These high-Mg\# clinopyroxenes also have very variable chromium content. Clinopyroxenes from type 5, zircon-bearing dikelets have moderate titanium content over a wide range of $\mathrm{Mg \#}$ values (Figs. 7, 9).

Mineral compositions in Site 920 dikelets and intervals do not vary downhole in a systematic way (Fig. 10). Different types of dikelets of different thicknesses and with contrasting mineral chemistry are commonly found in a single core (e.g., Core 153-920D-18R; Figs. $2,10)$. Similarly, the thick gabbroic interval in Core 153-920B-13R contains four rock types with different mineral compositions (Fig. 7) over only $0.81 \mathrm{~m}$ of core.

\section{CHEMICAL INTERACTIONS BETWEEN COARSE- GRAINED MAGMATIC ROCKS AND THEIR ULTRAMAFIC HOST ROCK}

Serpentinized peridotites sampled away from dikelets in the core from Site 920 have homogeneous primary compositions (Tables 4 , 5): $\mathrm{Mg} \#$ values range from $90 \%$ to $91 \%$ in olivine and orthopyroxene, from $91 \%$ to $93.5 \%$ in clinopyroxene, and from $65 \%$ to $72 \%$ in spinel. $\mathrm{Al}_{2} \mathrm{O}_{3}$ content in orthopyroxene $(3.6 \%-4.8 \%)$ and $\mathrm{Cr} \#$ in spinel $(0.23$ to 0.31$)$ are consistent with these rocks being residues of moderate degrees of partial melting and are in agreement with their clinopyroxene-bearing harzburgitic primary mineralogy (Shipboard Scientific Party, 1995).

In serpentinized peridotites sampled near dikelets, the composition of primary minerals is modified to variable extents: the dominant modification is an enrichment in iron of olivine, of orthopyroxene, and, to a lesser extent, spinel. Clinopyroxene near dikelets generally has higher sodium content, spinel is variably enriched in titanium, and olivine nickel content is commonly reduced.

\section{Olivine}

The width of the zone of chemical modification near a dikelet, and the extent of this modification, can be best tested on olivine because, as the most abundant primary mineral, it forms the groundmass of the 


\begin{tabular}{|c|c|c|c|c|c|c|c|c|c|c|c|c|c|c|c|c|}
\hline \multirow{2}{*}{$\begin{array}{l}\text { Sample: } \\
\text { Mineral: }\end{array}$} & \multicolumn{3}{|c|}{ 920D-18R-3, 122-127cm } & \multicolumn{2}{|c|}{$\begin{array}{c}920 \mathrm{~B}-11 \mathrm{R}-1,110-119 \\
\mathrm{~cm}\end{array}$} & \multirow{2}{*}{$\begin{array}{c}\begin{array}{c}920 \mathrm{~B}-10 \mathrm{R}-3, \\
0-9 \mathrm{~cm}\end{array} \\
\mathrm{Cpx}\end{array}$} & \multicolumn{2}{|c|}{$\begin{array}{c}920 \mathrm{~B}-1 \mathrm{~W}-2 \\
55-63 \mathrm{~cm}\end{array}$} & \multicolumn{3}{|c|}{$920 \mathrm{D}-18 \mathrm{R}-3,48-50 \mathrm{~cm}$} & \multicolumn{4}{|c|}{$920 \mathrm{~B}-2 \mathrm{R}-1,94-100 \mathrm{~cm}$} & \multirow{2}{*}{$\begin{array}{c}\begin{array}{c}920 \mathrm{~B}-11 \mathrm{R}-1, \\
0-5 \mathrm{~cm}\end{array} \\
\mathrm{Cpx}\end{array}$} \\
\hline & Cpx & Opx & Am & Cpx & Opx & & Cpx & Am & Cpx & Am & PI & Cpx & Opx & Am & $\mathrm{PI}$ & \\
\hline $\mathrm{Na}_{2} \mathrm{O}$ & 0.57 & 0.08 & 3.05 & 0.53 & 0.01 & 0.24 & 0.44 & 2.61 & 0.37 & 2.68 & 5.20 & 0.47 & 0.01 & 3.14 & 3.71 & 0.13 \\
\hline $\begin{array}{ll}\mathrm{N}_{2} 2 \mathrm{O} \\
\mathrm{Cr}_{2} \mathrm{O}_{3}\end{array}$ & 0.22 & 0.08 & 0.17 & 0.16 & 0.05 & 0.15 & 0.03 & 0.88 & 0.47 & 0.64 & 0.00 & 0.16 & 0.05 & 1.34 & 0.14 & 0.02 \\
\hline $\mathrm{MgO}$ & 14.63 & 24.26 & 14.39 & 15.74 & 28.05 & 18.16 & 14.64 & 13.97 & 16.16 & 14.33 & 0.02 & 15.52 & 28.25 & 16.51 & 0.02 & 14.02 \\
\hline $\mathrm{AlO}_{3}$ & 3.1 & 15 & 10.73 & 27 & 118 & 2.67 & 1.43 & 10.41 & 3.08 & 11.44 & 28.52 & 2.14 & 0.7 & 11.34 & 30.68 & 1.2 \\
\hline $\begin{array}{l}\mathrm{A}_{2} \mathrm{~A}_{3} \\
\mathrm{SiO}_{2}\end{array}$ & $\begin{array}{r}3.1 \\
51.1\end{array}$ & $53^{1.3}$ & $\begin{array}{l}10.13 \\
43.99\end{array}$ & 51.7 & $\begin{array}{r}1.18 \\
54.67\end{array}$ & 52.58 & $\begin{array}{r}1.43 \\
52.32\end{array}$ & $\begin{array}{l}10.41 \\
42.99\end{array}$ & $\begin{array}{r}3.08 \\
51.79\end{array}$ & $\begin{array}{l}11.44 \\
42.48\end{array}$ & $\begin{array}{l}28.92 \\
54.70\end{array}$ & 52.48 & $\begin{array}{c}0.1 \\
54.91\end{array}$ & $\begin{array}{l}111.34 \\
43.59\end{array}$ & $\begin{array}{r}51.42 \\
51.42\end{array}$ & 51.93 \\
\hline $\begin{array}{ll}\mathrm{CaO}_{2} \\
\mathrm{CaO}\end{array}$ & 21.64 & 3.2 & 11.04 & 21.64 & $\begin{array}{c}5.07 \\
1.3\end{array}$ & 20.63 & 20.99 & 11.18 & 21.55 & 11.64 & 10.86 & 22.06 & 1.02 & 11.24 & 13.58 & 24.7 \\
\hline $\begin{array}{l}\mathrm{CaO} \\
\mathrm{TiO}_{2}-2\end{array}$ & $\begin{array}{r}21.64 \\
1.07\end{array}$ & 0.5 & $\begin{array}{r}11.04 \\
2.34\end{array}$ & $\begin{array}{l}21.64 \\
1.3\end{array}$ & 0.53 & $\begin{array}{r}20.63 \\
0.54\end{array}$ & $\begin{array}{r}20.99 \\
0.49\end{array}$ & $\begin{array}{r}11.18 \\
3.48\end{array}$ & $\begin{array}{r}21.55 \\
1.38\end{array}$ & $\begin{array}{r}11.64 \\
5.15\end{array}$ & $\begin{array}{r}10.86 \\
0.11\end{array}$ & $\begin{array}{r}22.06 \\
0.77\end{array}$ & $\begin{array}{l}1.02 \\
0.32\end{array}$ & $\begin{array}{r}11.24 \\
2.63\end{array}$ & $\begin{array}{r}13.58 \\
0.01\end{array}$ & $\begin{array}{r}24 . / \\
0.45\end{array}$ \\
\hline $\begin{array}{l}\mathrm{MO}_{2} \\
\mathrm{MnO}\end{array}$ & $\begin{array}{l}1.07 \\
0.23\end{array}$ & 0.41 & $\begin{array}{l}2.34 \\
0.11\end{array}$ & $\begin{array}{l}1.3 \\
0.21\end{array}$ & 0.38 & $\begin{array}{l}0.54 \\
0.13\end{array}$ & $\begin{array}{l}0.49 \\
0.31\end{array}$ & $\begin{array}{l}3.48 \\
0.18\end{array}$ & $\begin{array}{l}1.38 \\
0.16\end{array}$ & 0.16 & 0.00 & 0.19 & 0.38 & $\begin{array}{l}2.03 \\
0.17\end{array}$ & 0.02 & 0.1 \\
\hline $\begin{array}{l}\mathrm{FeO} \\
\mathrm{FeO}\end{array}$ & 6.47 & $\begin{array}{r}0.41 \\
16.62\end{array}$ & $\begin{array}{r}0.11 \\
10.62\end{array}$ & 5.25 & $\begin{array}{l}0.30 \\
13.25\end{array}$ & 4.17 & $\begin{array}{l}8.87 \\
8.87\end{array}$ & $\begin{array}{r}10.82 \\
10.82\end{array}$ & 4.77 & 8.11 & 0.14 & 5.58 & 14.24 & 6.51 & 0.37 & 6.07 \\
\hline $\mathrm{NiO}$ & 0.01 & 0.04 & 0.04 & 0.04 & 0.03 & 0.05 & 0 & 0.03 & 0.02 & & & 0.03 & 0.07 & & & 0.01 \\
\hline $\mathrm{K}, \mathrm{O}$ & 0 & 0.02 & 0.23 & 0 & 0 & 0 & & 0.22 & & 0.26 & 0.14 & & & 0.15 & 0.03 & \\
\hline CalcTotal & 99.03 & 99.72 & 96.71 & 99.27 & 99.45 & 99.32 & 99.53 & 96.76 & 99.76 & 96.89 & 99.71 & 99.39 & 99.95 & 96.74 & 99.99 & 98.63 \\
\hline Mg\# & 80.131 & 72.245 & 70.723 & 84.245 & 79.055 & 88.596 & 74.641 & 69.722 & 85.805 & 75.903 & 23.634 & 83.227 & 77.952 & 81.886 & 7.551 & 80.449 \\
\hline
\end{tabular}

\begin{tabular}{|c|c|c|c|c|c|c|c|c|c|c|c|c|c|c|}
\hline \multirow{2}{*}{$\begin{array}{l}\text { Sample: } \\
\text { Mineral: }\end{array}$} & \multicolumn{2}{|c|}{$920 \mathrm{~B}-11 \mathrm{R}-2,118-127 \mathrm{~cm}$} & \multicolumn{2}{|c|}{$920 \mathrm{~B}-11 \mathrm{R}-1,100-108 \mathrm{~cm}$} & \multicolumn{2}{|c|}{$920 \mathrm{D}-13 \mathrm{R}-2,136-143 \mathrm{~cm}$} & \multicolumn{4}{|c|}{$920 \mathrm{D}-13 \mathrm{R}-2,132-134 \mathrm{~cm}$} & \multirow{2}{*}{$\begin{array}{l}920 \mathrm{D}-11 \mathrm{R}-3, \\
104-108 \mathrm{~cm}\end{array}$} & \multicolumn{3}{|c|}{$920 \mathrm{D}-2 \mathrm{R}-1,126-132 \mathrm{~cm}$} \\
\hline & $\mathrm{Cpx}$ & Opx & $\mathrm{Cpx}$ & Opx & $C_{p x}$ & Opx & $\mathrm{Cpx}$ & Opx & $\mathrm{Am}$ & $\mathrm{Pl}$ & & $\mathrm{Cpx}$ & Opx & $\mathrm{Am}$ \\
\hline $\mathrm{Na}_{2} \mathrm{O}$ & 0.41 & 0.02 & 0.53 & 0.04 & 0.32 & 0.04 & 0.35 & 0.003 & 2.88 & 6.81 & 0.49 & 0.53 & 0.03 & 2.34 \\
\hline $\mathrm{Cr}_{2} \mathrm{O}_{3}$ & 0.23 & 0.11 & 0.02 & 0.02 & 0.12 & 0.13 & 0.1 & 0.088 & 0.36 & 0.00 & 0.19 & 0.1 & 0.03 & 1.10 \\
\hline $\mathrm{MgO}$ & 15.22 & 28.26 & 12.22 & 17 & 14.95 & 25.07 & 13.27 & 22.48 & 11.86 & 0.00 & 16.65 & 13.14 & 21.7 & 13.91 \\
\hline $\mathrm{Al}_{2} \mathrm{O}_{3}$ & 2.72 & 1.47 & 1.74 & 0.51 & 1.24 & 1.28 & 2.14 & 1.077 & 11.39 & 27.26 & 1.04 & 0.91 & 0.37 & 9.04 \\
\hline $\mathrm{SiO}_{2}$ & 51.83 & 54.89 & 51.62 & 51.33 & 52.79 & 53.19 & 52.47 & 52.76 & 42.93 & 58.42 & 53.68 & 51.94 & 52.98 & 44.91 \\
\hline $\mathrm{CaO}$ & 22.12 & 1.24 & 20.66 & 2.18 & 21.38 & 1.25 & 21.59 & 2.468 & 11.37 & 8.83 & 22.07 & 20.5 & 1.73 & 10.83 \\
\hline $\mathrm{TiO}_{2}$ & 1.02 & 0.5 & 0.65 & 0.27 & 0.4 & 0.44 & 0.62 & 0.464 & 4.61 & 0.05 & 0.66 & 0.36 & 0.22 & 3.17 \\
\hline MnÓ & 0.24 & 0.38 & 0.41 & 0.78 & 0.26 & 0.43 & 0.28 & 0.518 & 0.2 & 0.00 & 0.16 & 0.36 & 0.73 & 0.18 \\
\hline $\mathrm{FeO}$ & 5.51 & 12.96 & 12.25 & 27.77 & 7.83 & 17.5 & 9.94 & 20.546 & 12.78 & 0.13 & 4.73 & 11.22 & 21.84 & 11.82 \\
\hline $\mathrm{NiO}$ & 0.03 & 0.07 & 0.02 & 0.01 & 0 & 0.04 & 0.07 & & 0.07 & 0.02 & 0.04 & 0.07 & 0.03 & \\
\hline $\mathrm{K}_{2} \mathrm{O}$ & & & & & & & & & 0.09 & 0.01 & & & & 0.20 \\
\hline CalcTotal & 99.31 & 99.9 & 100.11 & 99.91 & 99.31 & 99.37 & 100.82 & 100 & 98.55 & 101.530 & 99.73 & 99.14 & 99.65 & 97.58 \\
\hline Mg\# & 83.118 & 79.546 & 64.002 & 52.179 & 77.294 & 71.867 & 70.415 & & 62.308 & & 86.253 & 67.617 & 63.913 & 67.727 \\
\hline Anorthite & & & & & & & & & & 41.719 & & & & \\
\hline
\end{tabular}

Table 3 (continued)

\begin{tabular}{|c|c|c|c|c|c|c|c|c|c|c|c|c|c|c|}
\hline \multirow{2}{*}{$\begin{array}{l}\text { Sample: } \\
\text { Mineral: }\end{array}$} & \multicolumn{4}{|c|}{$920 \mathrm{D}-22 \mathrm{R}-5,132-141 \mathrm{~cm}$} & \multicolumn{4}{|c|}{$920 \mathrm{D}-11 \mathrm{R}-1,40-49 \mathrm{~cm}$} & \multicolumn{3}{|c|}{$920 \mathrm{D}-2 \mathrm{R}-1,104-106 \mathrm{~cm}$} & \multicolumn{3}{|c|}{$920 \mathrm{~B}-13 \mathrm{R}-4,45-50 \mathrm{~cm}$} \\
\hline & Cpx & Opx & Am & PI & Cpx & PI & Ol & Spi & Cpx & Am & $\mathrm{Pl}$ & Cpx & Opx & PI \\
\hline $\mathrm{Na}_{2} \mathrm{O}$ & 0.58 & 0.05 & 2.78 & 2.60 & 0.3 & 1.6 & 0 & 0 & 0.49 & 3.019 & 6.589 & 0.4 & 0.08 & 8.05 \\
\hline $\mathrm{Cr}_{2} \mathrm{O}_{3}$ & 0.17 & 0.15 & 1.09 & 0.02 & 1.15 & 0.01 & 0 & 38.26 & 0.01 & 0.019 & 0.016 & 0 & 0 & 0.02 \\
\hline $\mathrm{MgO}$ & 14.31 & 26.09 & 16.11 & 0.05 & 16.57 & 0.05 & 46.53 & 11.12 & 12.17 & 11.52 & 0.02 & 12.25 & 16.86 & 0.01 \\
\hline $\mathrm{Al}_{2} \mathrm{O}_{3}$ & 2.9 & 1.48 & 10.70 & 32.58 & 3.49 & 34.39 & 0 & 25.76 & 1.78 & 11.344 & 26.104 & 0.94 & 0.5 & 24.25 \\
\hline $\mathrm{SiO}_{2}$ & 51.3 & $\begin{array}{r}53.63 \\
\end{array}$ & 42.73 & 48.84 & 52.07 & 46.78 & 40.01 & 0.01 & 51.11 & 42.193 & 58.676 & 51.32 & 50.87 & 60.44 \\
\hline $\mathrm{CaO}$ & 20.81 & 2.14 & 10.89 & 15.63 & 22.31 & 17.43 & 0.04 & 0 & 20.47 & 11.168 & 8.669 & 16.76 & 1.91 & 6.47 \\
\hline & 0.96 & 0.47 & 3.49 & 0.01 & 0.57 & 0.07 & 0.02 & 1.4 & 0.63 & 2.465 & 0.005 & 0.41 & 0.3 & 0.12 \\
\hline $\mathrm{MnO}$ & 0.27 & 0.41 & 0.05 & 0.04 & 0.11 & 0.09 & 0.17 & 0.45 & 0.44 & 0.165 & 0.114 & 0.62 & 0.88 & 0.01 \\
\hline $\mathrm{FeO}$ & 7.82 & 15.54 & 8.13 & 0.52 & 3.29 & 0.15 & 12.59 & 22.55 & 12.44 & 15.487 & 0.244 & 16.82 & 28.5 & 0.41 \\
\hline $\mathrm{NiO}$ & 0 & 0.05 & & & 0.04 & & 0.25 & 0.12 & 0.06 & 0.008 & & 0 & 0.04 & \\
\hline $\mathrm{K}_{2} \mathrm{O}$ & & & 0.13 & 0.00 & & 1006 & & & & 0.036 & 0.007 & & & 0.18 \\
\hline CalcTotal & 99.12 & 100.01 & 96.16 & 100.31 & 99.91 & 100.61 & 99.62 & 99.68 & 99.61 & 97.424 & 100 & 99.53 & 99.94 & 99.95 \\
\hline $\begin{array}{l}\text { Mg\# } \\
\text { Anorthite }\end{array}$ & 76.55 & 74.956 & 77.933 & $\begin{array}{l}13.531 \\
76.832\end{array}$ & 89.977 & 85707 & 86.819 & 46.794 & 63.552 & 57.008 & & 56.482 & 51.334 & $\begin{array}{r}4.167 \\
30.435\end{array}$ \\
\hline & & & & & & 85.707 & & & & & 41.557 & & & \\
\hline
\end{tabular}


Table 3 (continued).

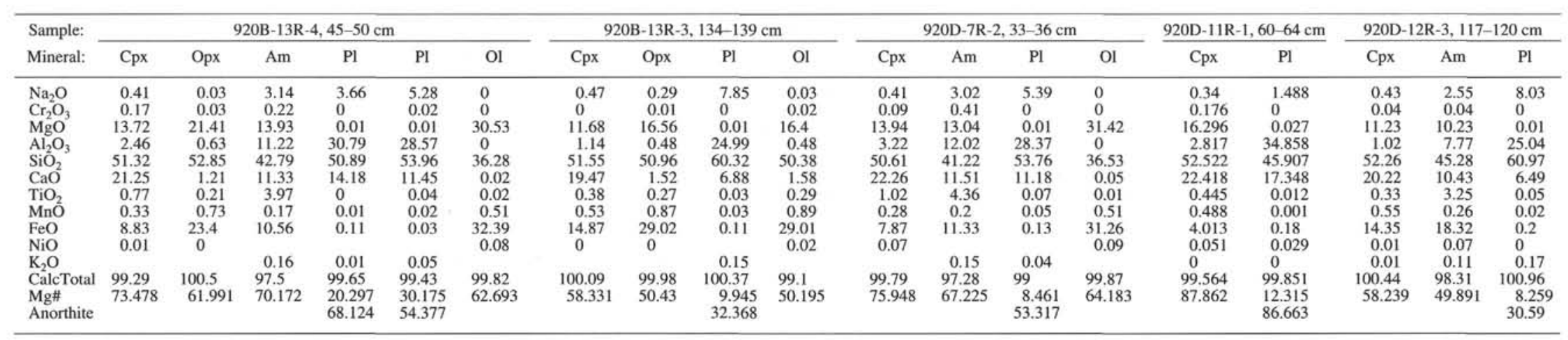

Table 3 (continued).

\begin{tabular}{|c|c|c|c|c|c|c|c|c|c|c|c|}
\hline \multirow{2}{*}{$\begin{array}{l}\text { Sample: } \\
\text { Mineral: }\end{array}$} & \multicolumn{2}{|c|}{$920 \mathrm{D}-13 \mathrm{R}-1,71-76 \mathrm{~cm}$} & \multicolumn{2}{|c|}{$920 \mathrm{D}-18 \mathrm{R}-2,103-106 \mathrm{~cm}$} & \multirow{2}{*}{$\begin{array}{l}\text { 920B-13R-3, } \\
\frac{113-117 \mathrm{~cm}}{\mathrm{Cpx}}\end{array}$} & \multirow{2}{*}{$\begin{array}{c}\text { 920D-18R-2, } \\
108-113 \mathrm{~cm}\end{array}$} & \multicolumn{2}{|c|}{$920 \mathrm{D}-14 \mathrm{R}-2,114-120 \mathrm{~cm}$} & \multicolumn{2}{|c|}{$\begin{array}{l}920 \mathrm{~B}-8 \mathrm{R}-5, \\
108-114 \mathrm{~cm}\end{array}$} & \multirow{2}{*}{$\begin{array}{c}920 \mathrm{D}-18 \mathrm{R}-3, \\
88-93 \mathrm{~cm} \\
\mathrm{Cpx}\end{array}$} \\
\hline & Cpx & Opx & Cpx & Am & & & Cpx & PI & Cpx & $\mathrm{Pl}$ & \\
\hline $\mathrm{Na}_{2} \mathrm{O}$ & 0.52 & 0.03 & 0.66 & 2.71 & 0.57 & 0.37 & 0.34 & & 0.26 & 2.78 & 0.47 \\
\hline $\mathrm{Cr}_{2} \mathrm{O}_{3}$ & 0.14 & 0.08 & 0.07 & 0.08 & 0.01 & 0.73 & 1.29 & & 1.22 & 0.00 & 0.47 \\
\hline $\mathrm{MgO}$ & 14.43 & 25.97 & 13.69 & 11.77 & 12.99 & 16.81 & 16.31 & & 18.81 & 0.05 & 16.31 \\
\hline $\mathrm{Al}_{2} \mathrm{O}_{3}$ & 2.14 & 1.14 & 1.69 & 9.62 & 2.56 & 2.71 & 3.45 & & 5.36 & 31.50 & 3.19 \\
\hline $\mathrm{SiO}_{2}$ & 51.35 & 53.52 & 52.38 & 43.14 & 50.94 & 52.40 & 51.95 & 47.02 & 51.86 & 48.79 & \\
\hline $\mathrm{CaO}^{2}$ & 19.93 & 1.32 & 21.83 & 11.13 & 20.52 & 22.50 & 23.07 & 16.96 & 18.16 & 15.11 & 22.35 \\
\hline $\mathrm{TiO}_{2}$ & 0.84 & 0.4 & 0.42 & 2.82 & 0.9 & 1.05 & 0.36 & 0 & 0.11 & 0.00 & 1.63 \\
\hline $\mathrm{MnO}$ & 0.31 & 0.38 & 0.34 & 0.19 & 0.33 & 0.06 & 0.09 & 0.04 & 0.13 & 0.01 & 0.15 \\
\hline $\mathrm{FeO}$ & 10.1 & 17.72 & 9.02 & 15.73 & 10.64 & 3.54 & 2.31 & 0.22 & 4.07 & 0.14 & 3.87 \\
\hline $\mathrm{NiO}$ & 0.07 & 0.06 & 0 & 0.04 & 0 & 0.07 & 0.01 & & 0.02 & & 0.05 \\
\hline $\mathrm{K}_{2} \mathrm{O}$ & 0.01 & 0 & 0.01 & 0.35 & 0 & & & 0 & & 0.06 & \\
\hline CalcTotal & $1 \quad 99.84$ & 100.6 & 100.11 & 97.56 & 99.47 & 100.23 & 99.18 & 100.29 & 99.99 & 98.44 & 99.27 \\
\hline Mg\# & 71.814 & 72.322 & 73.015 & 57.159 & 68.523 & 89.440 & 92.647 & & 89.180 & 36.444 & 88.26 \\
\hline Anorthite & & & & & & & & 84.619 & & 74.718 & \\
\hline
\end{tabular}




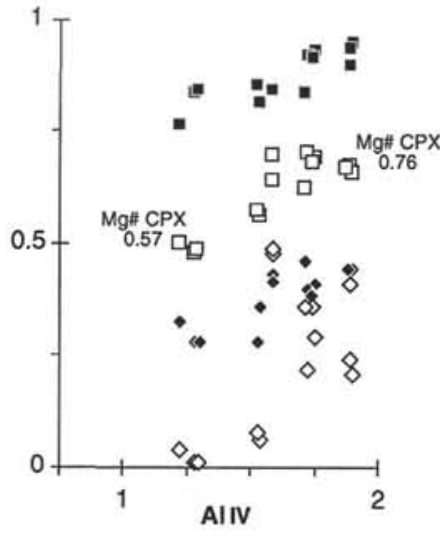

amphibole in thick gabbroic

$$
\begin{array}{cc}
\text { intervals: } & \\
\text { n } \mathrm{Na}+\mathrm{K} & -\mathrm{TiO}_{2} / 10 \\
\square \mathrm{Mg \#} & \diamond \mathrm{Cr}_{2} \mathrm{O}_{3}
\end{array}
$$

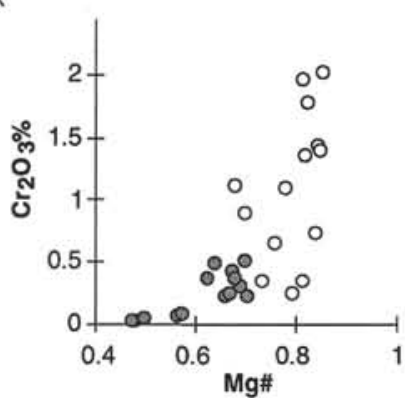

amphibole in o dikelets

- thick gabbroic intervals
Figure 8. Compositional variations in brown amphibole occurring as inclusions in pyroxenes, or as interstitial grains, in thick gabbroic intervals $(\mathrm{Mg} \#$ $\mathrm{CPX}=\mathrm{Mg} \#$ in clinopyroxene from these gabbroic intervals) and in thinner gabbroic dikelets from Site 920. rock. Olivine composition profiles made near various types of dikelets in the least serpentinized samples from Holes 920B and 920D are shown in Figure 11. We studied thin sections cut perpendicular to margins of the dikelets. In these thin sections, the maximum distance between a dikelet and fresh olivine from the host peridotite is $3.5 \mathrm{~cm}$. Although there is a general decrease of $\mathrm{Mg} \#$ toward dikelets, the amplitude of this decrease, and the distance over which olivines are enriched in iron relative to the unmodified $0.90-0.91 \mathrm{Mg}$ \# values, are variable. Five trends can be distinguished (Fig. 11).

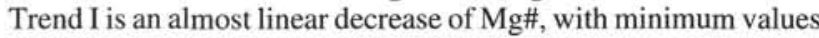
of about $82 \%$ against the dikelet margin, and $\mathrm{Mg} \#$ of less than $86 \%$ $1.5-2 \mathrm{~cm}$ from the dikelet. A linear extrapolation of this trend suggests that olivine could be modified as much as about $5 \mathrm{~cm}$ away from the dikelet.

Trend $\mathrm{I}^{\prime}$ reaches down to $\mathrm{Mg} \#$ values of $76 \%-77 \%$ against the dikelet, with $\mathrm{Mg} \#$ values that are still below $82 \% 1-1.5 \mathrm{~cm}$ away from the dikelet. Of the two samples that present this trend, one shows a step-like $\mathrm{Mg} \#$ decrease and the other shows a rapid decrease of Mg\# within about $0.2 \mathrm{~cm}$ from the dikelet's margin, a sharp inflection point, then a flatter linear trend, which can be extrapolated to unmodified Mg\# values 5-6 cm from the dikelet.

Trend II extends down to $\mathrm{Mg} \#$ values of $76 \%-80 \%$ against the dikelet and up to unmodified $\mathrm{Mg}$ \# between 1.5 and $3 \mathrm{~cm}$ away from the dikelet. Trend $\mathrm{II}^{\prime}$ has similar bounding $\mathrm{Mg \#}$ values, but a steeper
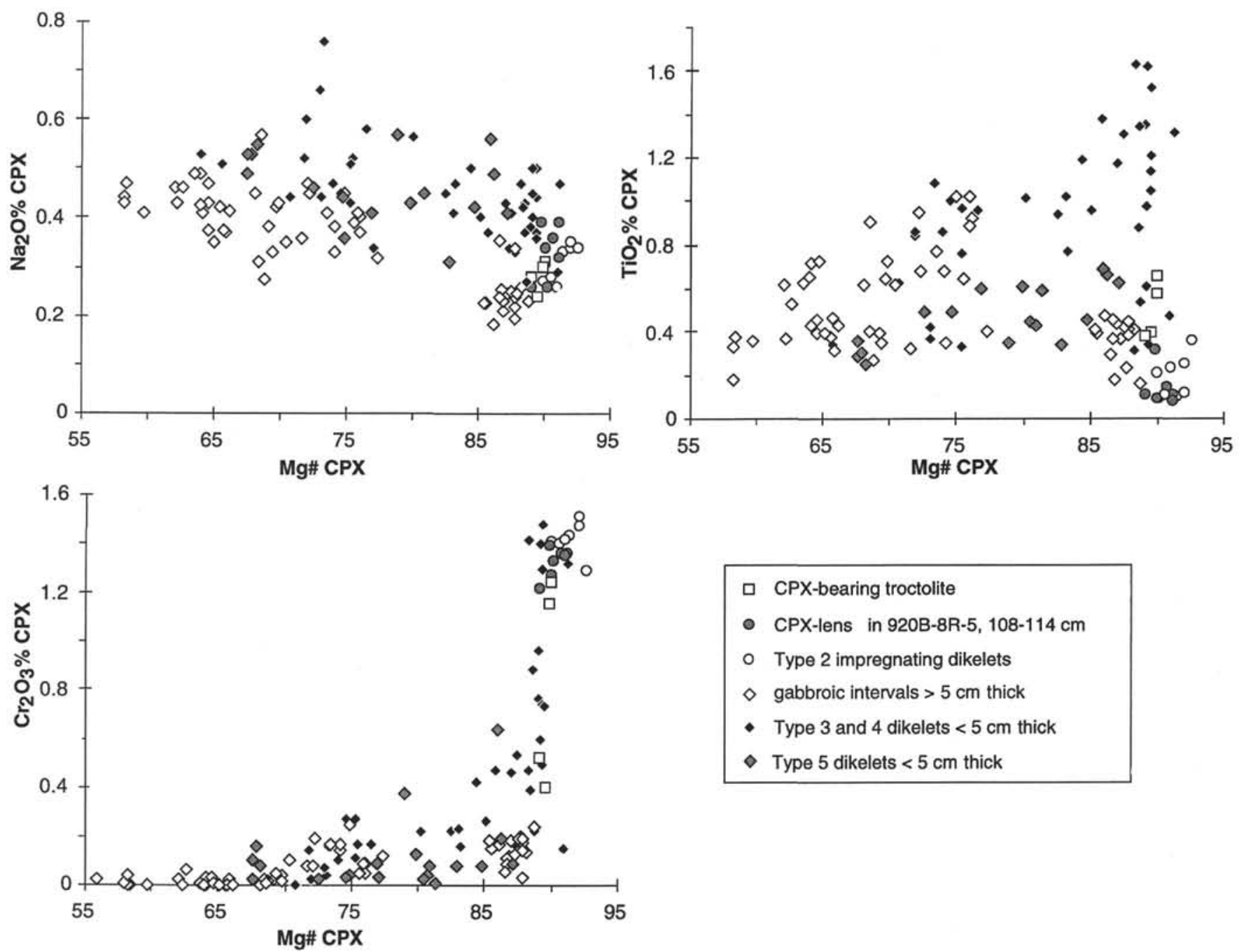
ㄷ CPX-bearing troctolite
- CPX-lens in 920B-8R-5, 108-114 cm
- Type 2 impregnating dikelets
$\diamond$ gabbroic intervals $>5 \mathrm{~cm}$ thick
- Type 3 and 4 dikelets $<5 \mathrm{~cm}$ thick
$\checkmark$ Type 5 dikelets $<5 \mathrm{~cm}$ thick

Figure 9. Compositional variations in clinopyroxene (CPX) from the various types of magmatic rocks found in the serpentinized peridotites from Site 920. 


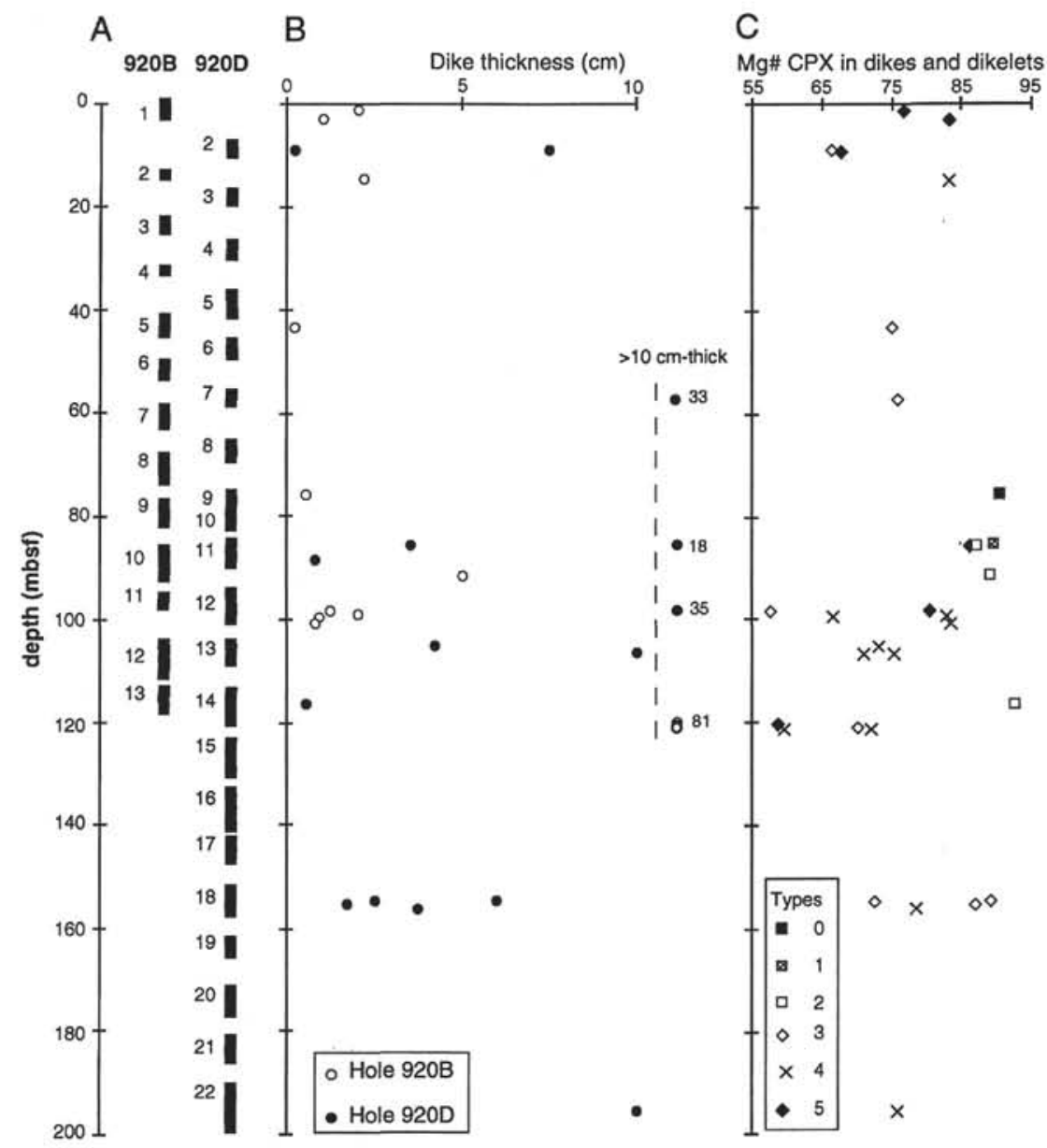

Figure 10. Downhole plot of (B) dikelet thickness and of (C) average clinopyroxene (CPX) Mg\# for the gabbroic rocks listed in Table 2. Black boxes in A show the length of material that was recovered in each core. $\mathbf{B}$ is an extract of Figure 4B. Symbols in C refer to the lithologic types listed in Table 2.

slope, with unmodified $\mathrm{Mg} \#$ between 1 and $1.5 \mathrm{~cm}$ away from the dikelet. Finally, trend III corresponds to olivine $\mathrm{Mg \#}$ values that are modified only within 0.1 to $0.3 \mathrm{~cm}$ from the dikelet's margin.

Figure 12 shows the evolution of $\mathrm{NiO}$ content in olivine, as $\mathrm{Mg \#}$ decrease near dikelets. This plot only includes samples for which we used a long counting time $(60 \mathrm{~s})$ and high current $(80 \mathrm{nA})$, an analytical procedure that gives olivine $\mathrm{NiO}$ values that are reproducible within $0.02 \%$. It shows three $\mathrm{NiO} / \mathrm{Mg}$ \# trends: trends A and B correspond to strong decreases of olivine $\mathrm{NiO}$ content toward the dikelets. In trend $\mathrm{C}$, by contrast, iron enrichment is not accompanied by nickel depletion. Our standard microprobing procedure ( $20 \mathrm{~s}$ at $40 \mathrm{nA})$ produces $\mathrm{NiO}$ contents that are only reproducible within $0.04 \%$. This is enough to identify these $\mathrm{NiO} / \mathrm{Mg} \#$ trends in samples that contain relics of olivine along dikelet margins (Table 6).

Samples for which we have been able to determine the Mg\#/distance to dikelet trend, the $\mathrm{NiO} / \mathrm{Mg} \#$ trend, and the type of dikelet involved (Tables 2,6 ) consistently show the following association of these three characteristics:

\begin{tabular}{lcc}
\hline Ol Mg\#/distribution & NiO/Mg\# & Dikelet Type \\
\hline Trend I & Trend A & 4 \\
Trend I' & Trend B & 3,4 \\
Trend II & Trend B & 4 \\
Trend II' & Trend C & 5 \\
Trend III & Trend C & 5 \\
\hline
\end{tabular}

Sample 153-920D-18R-2, 108-113 cm, is a special case in which the $\mathrm{Mg \# /distance} \mathrm{trend} \mathrm{is} \mathrm{directed,} \mathrm{not} \mathrm{toward} \mathrm{the} \mathrm{diffuse} \mathrm{clinopyrox-}$ ene, plagioclase, and amphibole dikelets that cut the sample (Table 2 ), but upward, toward the gabbro in interval 153-920D-18R-2, 100$106 \mathrm{~cm}$ (Fig. 2). For this particular sample, the distances are arbitrarily represented in Figure 11 as if the top of Sample 153-920D-18R-2, $108-113 \mathrm{~cm}$, was actually the contact with the gabbro above. If this was truly the case, this sample would belong to the trend I group. However, olivine in this sample falls on trend B in Figure 12 and is therefore more likely to belong to the trend I' group in Figure 11 (the top of the sample would then be about $1 \mathrm{~cm}$ away from the margin of the gabbro).

This distance-to-dikelet approach does not address serpentinized peridotite samples that are associated with Type 2 dikelets. This is because thin dikelets of this type are actually irregular impregnation lenses (Fig. 3D) for which it is not possible to measure distances to the margins. This is also because olivine in the peridotite near these impregnation patches retains high $\mathrm{Mg \# ,} \mathrm{high} \mathrm{NiO}$, unmodified compositions. The case of the wider, Type 2, gabbroic interval in Section 153-920D-11R-1 (Fig. 6) is specific in that it is not in contact with serpentinized harzburgite but with serpentinized dunite, through a few centimeters of clinopyroxene-bearing troctolite. Olivine in the dunite is completely serpentinized. Olivine in the clinopyroxenebearing troctolite plots to the right of trend $\mathrm{A}$ in the $\mathrm{NiO} / \mathrm{Mg} \#$ diagram of Figure 12. 
Table 4. Serpentinized peridotite samples in this study, with a summary of spinel and clinopyroxene compositions.

\begin{tabular}{|c|c|c|c|c|c|c|c|c|}
\hline \multirow{3}{*}{$\begin{array}{l}\text { Core, section, } \\
\text { interval }(\mathrm{cm})\end{array}$} & \multicolumn{4}{|c|}{ Average mineral composition } & \multicolumn{4}{|c|}{ Number of analyses (range of composition) } \\
\hline & Cpx & Spi & & & Cpx & Spi & & \\
\hline & $\mathrm{Na}_{2} \mathrm{O} \%$ & $\mathrm{Cr} \#$ & $\mathrm{TiO}_{2} \%$ & $\mathrm{Mg \#}$ & $\mathrm{Na}_{2} \mathrm{O} \%$ & $\mathrm{Cr} \#$ & $\mathrm{TiO}_{2} \%$ & $\mathrm{Mg \#}$ \\
\hline \multicolumn{9}{|c|}{ Away from dikes and dikelets } \\
\hline \multicolumn{9}{|l|}{$\begin{array}{l}153-920 \mathrm{~B}- \\
12 \mathrm{R}-1,58-63 \\
12 \mathrm{R}-1,116-122 \\
\text { 12R-2, 104-109 } \\
\text { 12R-5, 59-65 } \\
12 \mathrm{R}-5,104-113 \\
13 \mathrm{R}-1,82-88 \\
13 \mathrm{R}-2,75-81 \\
13 \mathrm{R}-3,90-93\end{array}$} \\
\hline $\begin{array}{l}\text { 153-920D- } \\
\text { 12R-1, 124-128 } \\
\text { 14R-3, 121-127 } \\
\text { 14R-4, 29-35 } \\
\text { 16R-1, 14-20 } \\
\text { 19R-3, 2-7 } \\
20 \mathrm{R}-3,20-26 \\
22 \mathrm{R}-3,12-16\end{array}$ & $\begin{array}{l}0.065 \\
0.063 \\
0.083 \\
0.091 \\
0.077 \\
0.08 \\
0.085\end{array}$ & $\begin{array}{l}0.301 \\
0.291 \\
0.295 \\
0.298 \\
0.295 \\
0.303 \\
0.302\end{array}$ & $\begin{array}{l}0.056 \\
0.056 \\
0.054 \\
0.05 \\
0.07 \\
0.08 \\
0.063\end{array}$ & $\begin{array}{l}70.43 \\
67.92 \\
67.3 \\
69.28 \\
69.84 \\
69.41 \\
68.53\end{array}$ & $\begin{array}{c}3(0.06-0.07) \\
3(0.06-0.07) \\
6(0.06-0.09) \\
9(0.08-0.14) \\
3(0.07-0.09) \\
1 \\
5(0.08-0.09)\end{array}$ & $\begin{array}{l}5(0.297-0.307) \\
3(0.287-0.293) \\
7(0.288-0.304) \\
4(0.296-0.298) \\
4(0.294-0.3) \\
2(0.301-0.305) \\
3(0.294-0.306)\end{array}$ & $\begin{array}{l}(0.04-0.07) \\
(0.04-0.07) \\
(0.02-0.08) \\
(0.04-0.06) \\
(0.05-0.09) \\
(0.05-0.09)\end{array}$ & $\begin{array}{c}(69.89-71.24) \\
(67.34-68.43) \\
(64.97-68.95) \\
(68.84-69.73) \\
(69.33-70.4) \\
(69.2-69.62) \\
(68.4-68-66)\end{array}$ \\
\hline \multicolumn{9}{|c|}{ Near dikes and dikelets } \\
\hline $\begin{array}{l}153-920 \mathrm{~B}- \\
1 \mathrm{~W}-2,55-63 \\
1 \mathrm{~W}-3,100-108 \\
2 \mathrm{R}-1,47-50 \\
2 \mathrm{R}-1,94-100 \\
5 \mathrm{R}-1,58-62 \\
6 \mathrm{R}-3,48-56 \\
11 \mathrm{R}-1,100-108 \\
11 \mathrm{R}-1,110-119 \\
11 \mathrm{R}-1,131-140 \\
11 \mathrm{R}-2,118-127\end{array}$ & $\begin{array}{l}0.46 \\
0.428 \\
0.437 \\
0.394 \\
0.336 \\
0.16 \\
0.085 \\
0.504 \\
0.24 \\
0.467\end{array}$ & $\begin{array}{l}0 . \overline{3} \\
0.296 \\
0.38 \\
0.323 \\
0.311 \\
0.292 \\
0.59 \\
0.309 \\
-\end{array}$ & $\begin{array}{l}\overline{-} \overline{1} 1 \\
0.067 \\
0.16 \\
0.136 \\
0.06 \\
0.065 \\
0.25 \\
0.071 \\
-\end{array}$ & $\begin{array}{l}67.63 \\
66.84 \\
50.54 \\
57.83 \\
66.94 \\
69.42 \\
30.79 \\
57.46\end{array}$ & $\begin{array}{c}5(0.11-0.63) \\
4(0.36-0.57) \\
4(0.293-0.298) \\
5(0.27-0.5) \\
7(0.16-0.53) \\
1 \\
2(0.08-0.09) \\
7(0.27-0.63) \\
9(0.1-0.42) \\
3(0.43-0.5)\end{array}$ & $\begin{array}{c}3(0.299-0.301) \\
3(0.37-0.51) \\
4(0.307-0.528) \\
5(0.295-0.34) \\
4(0.309-0.314) \\
\frac{2}{-} \\
6(0.282-0.332) \\
-\end{array}$ & $\begin{array}{c}(0.06-0.09) \\
(0.04-0.1) \\
(0.08-0.29) \\
(0.06-0.24) \\
(0.05-0.08) \\
- \\
(0-0.14) \\
-\end{array}$ & $\begin{array}{r}(65.59-69.05) \\
(63.47-68.67) \\
(40.15-56.52) \\
(40.4-70.23) \\
(64.56-67.92) \\
(69.29-69.54) \\
\\
(44.14-67.45)\end{array}$ \\
\hline $\begin{array}{l}\text { 153-920D- } \\
\text { 2R-1, 126-132 } \\
2 \mathrm{R}-2,39-47 \\
4 \mathrm{R}-2,9-13 \\
7 \mathrm{R}-1,67-70 \\
7 \mathrm{R}-1,76-83 \\
10 \mathrm{R}-2,48-52 \\
11 \mathrm{R}-3,104-108 \\
11 \mathrm{R}-4,4-9 \\
12 \mathrm{R}-3,82-86 \\
13 \mathrm{R}-2,136-143 \\
14 \mathrm{R}-2,114-120 \\
16 \mathrm{R}-6,126-132 \\
18 \mathrm{R}-1,10-16 \\
18 \mathrm{R}-1,38-44 \\
18 \mathrm{R}-2,108-113 \\
\text { I8R-3, 23-29 } \\
\text { 18R-3, 48-50 } \\
\text { 18R-3, 83-88 } \\
\text { 18R-3, 122-127 } \\
\text { 20R-3, 95-101 } \\
22 \mathrm{R}-4,110-115 \\
22 \mathrm{R}-5,132-141\end{array}$ & $\begin{array}{l}0.27 \\
0.31 \\
\overline{-} \\
0.63 \\
0.13 \\
0.567 \\
0.12 \\
0.326 \\
0.247 \\
0.31 \\
0.114 \\
0 . \overline{09} \\
0.42 \\
0.54 \\
0.45 \\
0.365 \\
0.39 \\
0.374 \\
0.07 \\
0.315\end{array}$ & $\begin{array}{l}0.322 \\
0.311 \\
0.517 \\
0.312 \\
0.447 \\
0.315 \\
\overline{-} \\
0.289 \\
0.519 \\
0.31 \\
0.435 \\
0.301 \\
0.293 \\
0.308 \\
0.53 \\
0.553 \\
0.578 \\
0.383 \\
0.57 \\
0.3 \\
0.299 \\
0.598\end{array}$ & $\begin{array}{l}0.067 \\
0.07 \\
0.496 \\
0.097 \\
0.897 \\
0.072 \\
\overline{0} \\
0.08 \\
0.577 \\
0.083 \\
0.235 \\
0.067 \\
0.067 \\
0.065 \\
0.977 \\
1.114 \\
1.36 \\
0.13 \\
0.86 \\
0.055 \\
0.056 \\
0.41\end{array}$ & $\begin{array}{l}63.24 \\
68.6 \\
54.91 \\
59.33 \\
44.2 \\
68.94 \\
\\
69.82 \\
56.17 \\
54.85 \\
60.6 \\
68.48 \\
68.42 \\
63.86 \\
34.79 \\
30.93 \\
33.84 \\
52.51 \\
26.74 \\
54.4 \\
64.64 \\
16.02\end{array}$ & $\begin{array}{c}8(0.17-0.38) \\
6(0.08-0.91) \\
- \\
1 \\
4(0.11-0.17) \\
4(0.48-0.66) \\
4(0.05-0.31) \\
5(0.31-0.35) \\
3(0.08-0.33) \\
7(0.26-0.35) \\
5(0.08-0.17) \\
\overline{1} \\
8(0.37-0.51) \\
2(0.53-0.546) \\
2(0.4-0.5) \\
4(0.31-0.47) \\
1 \\
7(0.26-0.485) \\
3 \\
2(0.27-0.36)\end{array}$ & $\begin{array}{c}3(0.299-0.367) \\
3(0.311-0.312) \\
5(0.51-0.522) \\
6(0.309-0.318) \\
3(0.35-0.63) \\
5(0.31-0.32) \\
- \\
4(0.285-0.292) \\
3(0.512-0.529) \\
3(0.308-0.313) \\
2(0.426-0.444) \\
4(0.27-0.317) \\
3(0.274-0.306) \\
2(0.306-0.31) \\
6(0.468-0.577) \\
2 \\
2(0.533-0.624) \\
2(0.381-0.385) \\
1 \\
2(0.298-0.302) \\
3(0.286-0.307) \\
3(0.576-0.611)\end{array}$ & $\begin{array}{c}(0.05-0.09) \\
(0.06-0.09) \\
0.46-0.54 \\
(0.08-0.11) \\
(0.61-1.23) \\
(0.06-0.09) \\
- \\
(0.06-0.09) \\
(0.52-0.62) \\
(0.08-0.09) \\
(0.19-0.28) \\
(0-0.15) \\
(0.04-0.1) \\
(0.06-0.07) \\
(0.29-1.68) \\
(0.94-1.446) \\
(1.24-1.48)\end{array}$ & $\begin{array}{c}(62.59-63.77) \\
(67.2-69.39) \\
(50.66-57.47) \\
(53.29-65.78) \\
(34.94-48.85) \\
(67.08-70.42) \\
\\
(69.2-70.15) \\
(55.43-56.8) \\
(53.06-55.89) \\
(60.5-60.71) \\
(67.87-69.34) \\
(66.78-70.13) \\
(59.16-68.56) \\
(29.96-41.9) \\
(30.44-31.41) \\
(28-39.68) \\
(52.22-52.8)\end{array}$ \\
\hline \multicolumn{9}{|l|}{ In clinopyroxene lens } \\
\hline $\begin{array}{l}153-920 \mathrm{~B}- \\
8 \mathrm{R}-5,108-114\end{array}$ & 0.343 & 0.446 & 0.218 & 60.86 & $6(0.26-0.39)$ & $8(0.299-0.539)$ & $(0.05-0.35)$ & $(57.05-68.47)$ \\
\hline \multicolumn{9}{|l|}{ In dunite } \\
\hline $\begin{array}{l}\text { 153-920D- } \\
\quad 11 \mathrm{R}-1,27-32\end{array}$ & - & 0.444 & 0.526 & 49.36 & - & $5(0.438-0.457)$ & $(0.48-0.64)$ & $(48.13-50.39)$ \\
\hline \multicolumn{9}{|c|}{ In clinopyroxene-bearing troctolite } \\
\hline $11 \mathrm{R}-1,40-49$ & 0.282 & 0.504 & 1.358 & 46.31 & $4(0.24-0.31)$ & $4(0.499-0.507)$ & $(1.18-1.43)$ & $(45.75-46.79)$ \\
\hline
\end{tabular}

Notes: Abbreviations as in Table $2 ;-=$ not analyzed.

\section{Spinel and Clinopyroxene}

Because spinel and pyroxenes are unevenly distributed at the thinsection scale, we have not been able to systematically check their chemistry against distance to dikelet. Crude tests made on clinopyroxenes in a few samples, show, however, that $\mathrm{Mg \#}$ values are generally not modified (except when directly against some dikelets), and that sodium contents are generally high (at least within $1.5 \mathrm{~cm}$ of the dikelets), with erratic variations that can occur within one grain and that we have not studied systematically. Only three out of the 32 neardikelet samples listed in Table 4 have consistently sodium-poor cli- nopyroxene near the dikelet's margin. Two of these samples contain type 5, zircon-bearing dikelets. The dikelet in the third sample is altered beyond recognition of its primary mineralogy.

The average values and the range of variation of clinopyroxene sodium content, of spinel titanium content, and of spinel Mg\# and $\mathrm{Cr} \#$ are listed in Table 4 and plotted in Figure 13 for each studied sample. Because the minimum and maximum distances between clinopyroxene and spinel grains measured in each sample and the dikelet's margin are variable from one sample to another, these average values and their range of variation are used only as indications of broad trends in the peridotite/magma interactions. 
Table 5. Selected microprobe analyses of orthopyroxene, clinopyroxene, olivine, and spinel in serpentinized peridotites from Site 920.

\begin{tabular}{|c|c|c|c|c|c|c|c|c|c|c|c|c|c|c|c|c|c|c|c|c|}
\hline \multirow{2}{*}{$\begin{array}{l}\text { Sample: } \\
\text { Mineral: }\end{array}$} & \multicolumn{4}{|c|}{$153-920 \mathrm{~B}-12 \mathrm{R}-1,58-63 \mathrm{~cm}$} & \multicolumn{4}{|c|}{$920 \mathrm{~B}-12 \mathrm{R}-5,59-65 \mathrm{~cm}$} & \multicolumn{4}{|c|}{$20 \mathrm{~B}-13 \mathrm{R}-1,82-88 \mathrm{~cm}$} & \multicolumn{4}{|c|}{$920 \mathrm{D}-12 \mathrm{R}-1,124-128 \mathrm{~cm}$} & \multicolumn{4}{|c|}{$920 \mathrm{D}-14 \mathrm{R}-3,121-127 \mathrm{~cm}$} \\
\hline & Opx & Cpx & $\mathrm{Ol}$ & Spi & Opx & Cpx & Ol & Spi & Opx & Cpx & Ol & Spi & Opx & Cpx & $\mathrm{Ol}$ & Spi & Opx & Cpx & $\mathrm{Ol}$ & Spi \\
\hline $\mathrm{Na}_{2} \mathrm{O}$ & 0 & 0.06 & 0 & 0.01 & 0 & 0.07 & 0 & 0 & 0.01 & 0.08 & 0 & 0.02 & 0 & 0.07 & 0 & 0 & 0.01 & 0.06 & 0.01 & 0 \\
\hline $\mathrm{Cr}_{2} \mathrm{O}_{3}$ & 1.09 & 1.4 & 0 & 26.71 & 1.04 & 1.46 & 0.01 & 26.5 & 0.98 & 1.41 & 0.02 & 24.76 & 1 & 1.38 & 0 & 27.19 & 1.1 & 1.52 & 0 & 26.21 \\
\hline $\mathrm{MgO}$ & 31.76 & 16.38 & 49.61 & 17.05 & 31.73 & 16.29 & 49.49 & 16.83 & 32.24 & 15.76 & 49.42 & 16.39 & 32.63 & 15.94 & 49.58 & 17.41 & & 17.17 & 49.8 & 17.06 \\
\hline $\mathrm{Al}_{2} \mathrm{O}_{3}$ & 4.86 & 5.21 & 0 & 42.08 & 4.76 & 5.51 & 0.03 & 42.48 & 4.62 & 5.43 & 0 & 43.48 & 4.32 & 5.27 & 0 & 42.45 & 4.64 & 5.49 & 0 & 42.49 \\
\hline $\mathrm{SiO}_{2}$ & 54.5 & 51.3 & 40.57 & 0 & 55.41 & 51.56 & 41.3 & 0.05 & 54.8 & 50.76 & 40.98 & 0 & 55.16 & 51.02 & 41.34 & 0.01 & 53.53 & 50.35 & 40.13 & 0.04 \\
\hline $\mathrm{CaO}$ & 1.88 & 22.11 & 0.05 & 0 & 1.88 & 22.62 & 0.01 & 0.01 & 1.51 & 23.33 & 0.08 & 0 & 0.92 & 23.67 & 0.04 & 0.02 & 1.91 & 21.66 & 0.08 & 0.01 \\
\hline $\mathrm{TiO}_{2}$ & 0.08 & 0.1 & 0.01 & 0.08 & 0.07 & 0.14 & 0.01 & 0.03 & 0.03 & 0.16 & 0.01 & 0.04 & 0.04 & 0.09 & 0.01 & 0.07 & 0.07 & 0.11 & 0 & 0.07 \\
\hline MnÓ & 0.13 & 0.08 & 0.14 & 0.14 & 0.14 & 0.14 & 0.11 & 0.19 & 0.17 & 0.06 & 0.1 & 0.17 & 0.12 & 0.09 & 0.11 & 0.26 & 0.16 & 0.1 & 0.12 & 0.16 \\
\hline $\mathrm{FeO}$ & 5.88 & 2.73 & 9.05 & 13.73 & 5.79 & 2.47 & 9.22 & 13.79 & 5.97 & 2.3 & 9.28 & 14.26 & 6.23 & 2.56 & 9.41 & 12.97 & 5.91 & 2.99 & 9.33 & 14.03 \\
\hline $\mathrm{NiO}$ & 0.14 & 0.05 & 0.39 & 0.25 & 0.16 & 0.07 & 0.44 & 0.25 & 0.09 & 0.04 & 0.38 & 0.17 & 0.12 & 0.07 & 0.37 & 0.22 & 0.1 & 0.04 & 0.38 & 0.2 \\
\hline CalcTotal & 100.34 & 99.42 & 99.82 & 100.05 & 100.98 & 100.33 & 100.61 & 100.13 & 100.42 & 99.34 & 100.27 & 99.29 & 100.53 & 100.16 & 100.88 & 100.6 & 99.63 & 99.5 & 99.85 & 100.26 \\
\hline Mg\# & 90.592 & 91.46 & 90.722 & 68.88 & 90.719 & 92.158 & 90.543 & 68.515 & 90.59 & 92.422 & 90.471 & 67.202 & 90.329 & 91.739 & 90.373 & 70.519 & 90.659 & 91.11 & 90.494 & 68.434 \\
\hline
\end{tabular}

Note: Abbreviations as in Tables 2 and 3.

Table 5 (continued).

\begin{tabular}{|c|c|c|c|c|c|c|c|c|c|c|c|c|c|c|}
\hline \multirow{2}{*}{$\begin{array}{l}\text { Sample: } \\
\text { Mineral: }\end{array}$} & \multicolumn{4}{|c|}{$920 \mathrm{D}-16 \mathrm{R}-1,14-20 \mathrm{~cm}$} & \multicolumn{4}{|c|}{ 920D-19R-3, 2-7 cm } & \multicolumn{3}{|c|}{$920 \mathrm{D}-20 \mathrm{R}-3,20-26 \mathrm{~cm}$} & \multicolumn{3}{|c|}{$920 \mathrm{D}-22 \mathrm{R}-3,12-16 \mathrm{~cm}$} \\
\hline & Opx & $\mathrm{Cpx}$ & Ol & Spi & Opx & Cpx & Ol & Spi & Opx & Cpx & Ol & Opx & Cpx & Spi \\
\hline $\mathrm{Na}_{2} \mathrm{O}$ & 0.02 & 0.07 & 0 & 0.03 & 0 & 0.07 & 0 & 0.0 & 0.01 & 0.08 & 0 & 0 & 0.08 & 0 \\
\hline $\mathrm{Cr}_{2} \mathrm{O}_{3}$ & 0.92 & 1.33 & 0.01 & 26.73 & 0.96 & 1.46 & 0 & 27.02 & 0.91 & 1.26 & 0.02 & 0.88 & 1.25 & 26.29 \\
\hline $\mathrm{MgO}$ & 32.44 & 16.11 & 49.6 & 17.12 & 32.18 & 16.11 & 49.64 & 17.15 & 32.44 & 16.05 & 49.31 & 32.12 & 16.25 & 16.56 \\
\hline $\mathrm{Al}_{2} \mathrm{O}_{3}$ & 4.21 & 5.17 & 0 & 42.16 & 4.19 & 5.24 & 0 & 42.26 & 4.24 & 4.71 & 0 & 3.97 & 4.78 & 42.25 \\
\hline $\mathrm{SiO}_{2}$ & 54.6 & 51.28 & 40.57 & 0.02 & 54.8 & 50.52 & 40.83 & 0.01 & 54.87 & 51.1 & 40.52 & 54.71 & 51.05 & 0 \\
\hline $\mathrm{CaO}$ & 1.61 & 23.83 & 0.06 & 0.0 & 2.05 & 23.46 & 0.04 & 0 & 1.67 & 23.6 & 0.03 & 1.85 & 23.17 & 0.01 \\
\hline & 0.04 & 0.14 & 0 & 0. & 0.08 & 0.12 & 0.0 & 0. & 0.04 & 0.12 & 0 & 0.05 & 0.12 & 0.05 \\
\hline $\mathrm{MnO}$ & 0.15 & 0.1 & $0.1 \quad$ r & 0. & 0.14 & 0. & 0.12 & 0 & 0.14 & 0.1 & 0. & 0. & 0.11 & 0.13 \\
\hline $\mathrm{FeO}$ & 5.69 & 2 & 9. & 13 & 5.82 & 2.32 & 9.3 & 13. & 5.98 & 2.38 & 9. & 5.99 & 2.55 & 13.48 \\
\hline $\mathrm{NiO}$ & 0.1 & 0.07 & 0.38 & 0.2 & 0.09 & 0.03 & 0.36 & 0.24 & 0.12 & 0.05 & 0.37 & 0.08 & 0.02 & 0.19 \\
\hline Calc & 99.77 & 100.4 & 99.84 & 99.9 & 00.32 & 99.46 & 100.3 & 100.01 & 100.41 & 99.44 & 99.48 & 99.78 & 99.37 & 98.96 \\
\hline $\mathrm{Mg}$ & 91.047 & 92.57 & 90.696 & 69.289 & 90.784 & 92.538 & 90.462 & 70.033 & 90.63 & 92.322 & 90.611 & 90.534 & 91.918 & 68.661 \\
\hline
\end{tabular}

Table 5 (continued).

\begin{tabular}{|c|c|c|c|c|c|c|c|c|c|c|c|c|c|c|c|c|c|c|c|}
\hline \multirow{2}{*}{$\begin{array}{l}\text { Sample: } \\
\text { Mineral: }\end{array}$} & \multicolumn{9}{|c|}{$920 \mathrm{~B}-2 \mathrm{R}-1,47-50 \mathrm{~cm}$} & \multicolumn{10}{|c|}{$920 \mathrm{~B}-2 \mathrm{R}-1,94-100 \mathrm{~cm}$} \\
\hline & Opx & Opx & Opx & Opx & Cpx & Ol & OI & Spi & Spi & Opx & Opx & Opx & Cpx & Cpx & Ol & OI & Ol & Spi & Spi \\
\hline $\mathrm{Na}_{2} \mathrm{O}$ & 0.48 & 0.05 & 0.03 & 0.01 & 0.53 & 0.01 & 0 & 0.02 & 0.02 & 0.01 & 0.02 & 0.03 & 0.47 & 0.34 & 0.02 & 0 & 0 & 0.01 & 0.01 \\
\hline $\mathrm{Cr}_{2} \mathrm{O}_{3}$ & 1.1 & 0.87 & 0.79 & 0.73 & 1.28 & 0.01 & 0 & 26.17 & 26.17 & 0.55 & 0.56 & 0.4 & 1.36 & 1.46 & 0 & 0 & 0 & 28.93 & 40 \\
\hline $\mathrm{MgO}$ & 27.95 & 33.04 & 33.06 & 32.51 & 16.3 & 49.15 & 47.44 & 16.95 & 15.38 & 32.35 & 30.52 & 29.56 & 15.79 & 15.6 & 49.23 & 41.94 & 40.78 & 13.64 & 9.38 \\
\hline $\mathrm{Al}_{2} \mathrm{O}_{3}$ & 4.52 & 3.79 & 4.04 & 2.56 & 3.44 & 0 & 0 & 42.43 & 41.47 & 2.83 & 1.34 & 1.42 & 4.85 & 5.22 & 0 & 0 & 0 & 37.8 & 24.02 \\
\hline $\mathrm{SiO}_{2}$ & 54.42 & 55.88 & 54.72 & 55.36 & 52.52 & 40.4 & 39.98 & 0 & 0 & 54.59 & 55.45 & 54.69 & 51.39 & 50.72 & 40.8 & 38.46 & 38.56 & 0.02 & 0.04 \\
\hline $\mathrm{CaO}^{\circ}$ & 7.24 & 0.81 & 0.73 & 0.44 & 22.99 & 0.03 & 0.02 & 0.01 & 0.02 & 0.87 & 1.15 & 0.82 & 22.74 & 22.94 & 0.02 & 0.07 & 0.05 & 0 & 0.01 \\
\hline $\mathrm{TiO}_{2}$ & 0.06 & 0.03 & 0.02 & 0.02 & 0.07 & 0 & 0.01 & 0.1 & 0.04 & 0.04 & 0.06 & 0.3 & 0.13 & 0.09 & 0 & 0.01 & 0.01 & 0.08 & 0.29 \\
\hline $\mathrm{MnO}$ & 0.11 & 0.12 & 0.15 & 0.16 & 0.08 & 0.13 & 0.16 & 0.16 & 0.17 & 0.15 & 0.25 & 0.31 & 0.08 & 0.07 & 0.13 & 0.28 & 0.31 & 0.31 & 0.42 \\
\hline $\mathrm{FeO}$ & 4.98 & 6.37 & 6.29 & 8.18 & 2.15 & 9.48 & 11.74 & 13.9 & 15.78 & 7.64 & 10.62 & 12.14 & 2.73 & 2.69 & 9.55 & 18.66 & 19.98 & 18.71 & 24.9 \\
\hline $\mathrm{NiO}$ & 0.06 & 0.13 & 0.09 & 0.08 & 0.05 & 0.38 & 0.37 & 0.24 & 0.21 & 0.1 & 0.07 & 0.07 & 0.05 & 0.05 & 0.38 & 0.3 & 0.25 & 0.17 & 0.09 \\
\hline CalcTotal & 100.92 & 101.08 & 99.92 & 100.06 & 99.41 & 99.58 & 99.73 & 99.99 & 99.26 & 99.14 & 100.05 & 99.74 & 99.59 & 99.19 & 100.13 & 99.72 & 99.94 & 99.68 & 99.15 \\
\hline $\mathrm{Mg} \#$ & 90.912 & 90.239 & 90.361 & 87.631 & 93.095 & 90.24 & 87.811 & 68.49 & 63.468 & 88.307 & 83.669 & 81.282 & 91.152 & 91.176 & 90.182 & 80.026 & 78.44 & 56.521 & 40.159 \\
\hline
\end{tabular}


Table 5 (continued).

\begin{tabular}{|c|c|c|c|c|c|c|c|c|c|c|c|c|c|c|c|c|c|c|c|c|}
\hline \multirow{2}{*}{$\begin{array}{l}\text { Sample: } \\
\text { Mineral: }\end{array}$} & \multicolumn{4}{|c|}{$920 \mathrm{~B}-8 \mathrm{R}-5,108-114 \mathrm{~cm}$} & \multicolumn{6}{|c|}{$920 \mathrm{~B}-11 \mathrm{R}-2,118-127 \mathrm{~cm}$} & \multicolumn{10}{|c|}{$920 \mathrm{D}-2 \mathrm{R}-1,126-132 \mathrm{~cm}$} \\
\hline & Opx & Ol & Spi & Spi & Opx & Opx & Cpx & Cpx & Ol & $\mathrm{Ol}$ & Opx & Opx & Cpx & Cpx & Cpx & Ol & Ol & Ol & Ol & Spi \\
\hline $\mathrm{Na}_{2} \mathrm{O}$ & 0.01 & 0 & 0.01 & 0 & 0.03 & 0.01 & 0.47 & 0.43 & 0 & 0 & 0.16 & 0.01 & 0.41 & 0.27 & 0.17 & 0.02 & 0.01 & 0.04 & 0.02 & 0 \\
\hline 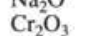 & 0.73 & 0 & $\begin{array}{r}42.56 \\
\end{array}$ & 27.51 & 1.02 & 0.37 & $\begin{array}{l}0.47 \\
1.35\end{array}$ & 0.88 & 0.02 & 0 & $\begin{array}{l}0.106 \\
1.06\end{array}$ & 0.2 & 1.34 & 1.13 & 1.38 & 0 & 0 & 0.01 & 0 & 26.07 \\
\hline $\begin{array}{l}\mathrm{MgO}_{2} \mathrm{U}^{3} \\
\mathrm{M}^{2}\end{array}$ & 32.58 & $\begin{array}{c}0 \\
48.8\end{array}$ & $\begin{array}{l}42.50 \\
13.06\end{array}$ & 16.76 & 30.91 & 30.46 & $\begin{array}{r}15.33 \\
1.32\end{array}$ & $\begin{array}{r}0.08 \\
15.91\end{array}$ & $\begin{array}{r}0.02 \\
45.19\end{array}$ & 43.42 & $\begin{array}{r}32.33 \\
\end{array}$ & $\begin{array}{c}29.49 \\
\end{array}$ & $\begin{array}{l}15.84 \\
15.8\end{array}$ & 16.6 & $\begin{array}{r}15.36 \\
15.68\end{array}$ & $\begin{array}{c}0 \\
48.42\end{array}$ & $\begin{array}{c}0 \\
48.19\end{array}$ & $\begin{array}{r}0.01 \\
48.96\end{array}$ & 39.95 & $\begin{array}{l}20.07 \\
15.39\end{array}$ \\
\hline $\mathrm{Al}_{2} \mathrm{O}_{3}$ & 3.77 & $\begin{array}{c}40.0 \\
0\end{array}$ & 25.23 & 40.4 & 4.54 & $\begin{array}{l}1.49 \\
1.49\end{array}$ & $\begin{array}{r}4.82 \\
\end{array}$ & 2.67 & 0 & 0 & $\begin{array}{r}3.79 \\
\end{array}$ & 0.85 & $\begin{array}{r}4.0 \\
\end{array}$ & 2.77 & 5.14 & 0 & 0 & $\begin{array}{l}40.90 \\
0\end{array}$ & 0 & 40.82 \\
\hline $\begin{array}{l}\mathrm{A}_{2} \mathrm{O}_{3} \mathrm{O}_{3} \\
\mathrm{SiO}_{3}\end{array}$ & 54.81 & $\begin{array}{c}0 \\
40.57\end{array}$ & $\begin{array}{r}2.23 \\
0.03\end{array}$ & $\begin{array}{r}40.4 \\
0.02\end{array}$ & $\begin{array}{r}4.34 \\
54.42\end{array}$ & $\begin{array}{r}1.49 \\
55.28\end{array}$ & $\begin{array}{r}4.82 \\
51.66\end{array}$ & $\begin{array}{r}2.67 \\
51.99\end{array}$ & 39.06 & $\begin{array}{c}38.88 \\
38\end{array}$ & 54.96 & $\begin{array}{r}0.83 \\
55.91\end{array}$ & $\begin{array}{r}4.9 \\
51.44\end{array}$ & 53.22 & 51.14 & $\begin{array}{c}0 \\
40.73\end{array}$ & $\begin{array}{c}0 \\
40.93\end{array}$ & $\begin{array}{c}0 \\
40.53\end{array}$ & $\begin{array}{c}0 \\
38.42\end{array}$ & $\begin{array}{r}40.82 \\
0.01\end{array}$ \\
\hline $\mathrm{CaO}$ & 1.26 & 0.02 & 0 & $\begin{array}{l}0.02 \\
0\end{array}$ & $\begin{array}{r}3.42 \\
2.33\end{array}$ & 0.89 & 23.07 & 22.6 & 0.03 & 0.02 & 0.87 & 0.62 & 23.32 & 23.79 & 23.55 & $\begin{array}{r}4.73 \\
0.02\end{array}$ & $\begin{array}{r}4.93 \\
0.01\end{array}$ & $\begin{array}{r}40.53 \\
0.05\end{array}$ & $\begin{array}{r}38.42 \\
0.03\end{array}$ & 0.01 \\
\hline $\mathrm{TiO}_{2}$ & 0.07 & 0.01 & 0.29 & 0.07 & 0.09 & $\begin{array}{l}0.49 \\
0.49\end{array}$ & 0.14 & 0.88 & 0.01 & $\begin{array}{l}0.02 \\
0\end{array}$ & 0.06 & 0.01 & 0.12 & 0.19 & 0.13 & 0.01 & 0 & 0 & 0 & 0.05 \\
\hline $\begin{array}{l}11 \mathrm{O}_{2} \\
\mathrm{MnO}\end{array}$ & 0.15 & 0.2 & $\begin{array}{l}0.29 \\
0.23\end{array}$ & $\begin{array}{l}0.07 \\
0.14\end{array}$ & $\begin{array}{l}.0 .16 \\
0.16\end{array}$ & $\begin{array}{l}0.49 \\
0.25\end{array}$ & $\begin{array}{l}0.14 \\
0.08\end{array}$ & $\begin{array}{l}0.88 \\
0.12\end{array}$ & $\begin{array}{l}0.01 \\
0.19\end{array}$ & $\begin{array}{l}0 \\
0.23\end{array}$ & $\begin{array}{l}0.00 \\
0.14\end{array}$ & $\begin{array}{l}0.01 \\
0.33\end{array}$ & $\begin{array}{l}0.12 \\
0.08\end{array}$ & $\begin{array}{l}0.19 \\
0.07\end{array}$ & 0.07 & $\begin{array}{l}0.01 \\
0.15\end{array}$ & 0.16 & 0.13 & 0.32 & 0.24 \\
\hline $\mathrm{FeO}$ & 6.22 & 9.53 & 18.1 & 13.97 & 6.29 & 10.2 & 2.87 & 3.66 & 14.15 & 16.64 & 6 & 12.22 & 2.12 & 1.95 & 2.45 & 10.31 & 10.68 & 9.29 & 20.76 & $\begin{array}{r}0.24 \\
16.39\end{array}$ \\
\hline $\mathrm{NiO}$ & 0.07 & 0.37 & 0.13 & 0.2 & 0.1 & 0.06 & 0.04 & 0.04 & 0.33 & 0.2 & 0.12 & 0.08 & 0.06 & 0.05 & 0.04 & 0.38 & 0.38 & 0.38 & 0.34 & 0.22 \\
\hline CalcTotal & 99.66 & 99.5 & 99.64 & 99.08 & 99.87 & 99.5 & 99.83 & 99.18 & 98.97 & 99.4 & 100.5 & 99.69 & 99.6 & 100.04 & 99.61 & 100.04 & 100.36 & 99.4 & 99.84 & 99.2 \\
\hline Mg\# & 90.327 & 90.13 & 56.255 & 68.145 & 89.76 & 84.192 & 90.492 & 88.577 & 85.063 & 82.306 & 90.567 & 81.143 & 92.997 & 93.811 & 91.944 & 89.331 & 88.943 & 90.376 & 77.424 & 62.593 \\
\hline
\end{tabular}

Table 5 (continued).

\begin{tabular}{|c|c|c|c|c|c|c|c|c|c|c|c|c|c|c|c|c|c|c|c|}
\hline \multirow{2}{*}{$\begin{array}{l}\text { Sample: } \\
\text { Mineral: }\end{array}$} & \multicolumn{6}{|c|}{$920 \mathrm{D}-14 \mathrm{R}-2,114-120 \mathrm{~cm}$} & \multicolumn{13}{|c|}{$920 \mathrm{D}-18 \mathrm{R}-2,108-113 \mathrm{~cm}$} \\
\hline & Opx & Opx & Cpx & Cpx & OI & Spi & Opx & Opx & Opx & Opx & Cpx & Cpx & Cpx & Cpx & Ol & OI & Spi & Spi & Spi \\
\hline $\mathrm{Na}_{2} \mathrm{O}$ & 0.04 & 0.03 & 0.33 & 0.35 & 0.01 & 0 & 0.03 & 0.02 & 0.01 & 0.01 & 0.39 & 0.5 & 0.46 & 0.47 & 0.01 & 0.01 & 0.01 & 0.02 & 0 \\
\hline $\mathrm{Cr}_{2} \mathrm{O}_{3}$ & 0.98 & 0.65 & 1.43 & 1.47 & 0.01 & 36.87 & 0.77 & 0.83 & 0.92 & 1.03 & 1.34 & 1.3 & 1.42 & 1.32 & 0.01 & 0.01 & 42.56 & 40.6 & 37.95 \\
\hline $\mathrm{MgO}^{2}$ & 32.11 & 33.08 & 15.53 & 15.84 & 49.11 & 14.4 & 31.6 & 29.96 & 31.18 & 28.92 & 15.16 & 15.59 & 15.03 & 15.75 & 47.82 & 41.58 & 9.8 & 8.19 & 7.59 \\
\hline $\mathrm{Al}_{2} \mathrm{O}_{3}$ & 4.03 & 2.4 & 5.36 & 4.62 & 0 & 30.96 & 3.6 & 3.35 & 4.17 & 4.35 & 4.62 & 4.41 & 4.74 & 4.66 & 0 & $\begin{array}{l}+1.00 \\
0\end{array}$ & 21.02 & 20.57 & 24.16 \\
\hline $\mathrm{SiO}_{2}$ & 55.44 & 56.14 & 51.16 & 51.37 & 40.76 & 0.01 & 54.01 & 53.49 & 54.48 & 52.82 & 50.63 & 50.89 & 50.64 & 50.82 & 40.27 & 38.58 & 0.06 & 0.03 & 0.01 \\
\hline $\mathrm{CaO}$ & 1.7 & 1.72 & 22.52 & 23.01 & 0.06 & 0 & 1.81 & 1.42 & 0.85 & 0.68 & 22.48 & 21.95 & 22.33 & 22.46 & 0.05 & 0.03 & 0 & 0 & 0 \\
\hline $\mathrm{TiO}_{2}$ & 0.08 & 0.22 & 0.1 & 0.25 & 0 & 0.28 & 0.06 & 0.07 & 0.02 & 0.02 & 0.4 & 1.21 & 0.14 & 1.32 & 0.04 & 0.01 & 1.21 & 1.68 & 0.53 \\
\hline $\mathrm{MnO}$ & 0.16 & 0.15 & 0.1 & 0.1 & 0.11 & 0.18 & 0.14 & 0.25 & 0.14 & 0.25 & 0.1 & 0.13 & 0.18 & 0.1 & 0.1 & 0.26 & 0.32 & 0.3 & 0.31 \\
\hline $\mathrm{FeO}$ & 6.17 & 6.29 & 2.59 & 2.43 & 9.47 & 16.76 & 7.04 & 10.09 & 8.25 & 11.67 & 3.53 & 3.3 & 4.13 & 2.69 & 11.33 & 18.45 & 24.22 & 27.38 & 28.19 \\
\hline $\mathrm{NiO}$ & 0.09 & 0.09 & 0.03 & 0.05 & 0.36 & 0.15 & 0.12 & 0.06 & 0.1 & 0.06 & 0.01 & 0.04 & 0.06 & 0.02 & 0.34 & 0.27 & 0.15 & 0.15 & 0.13 \\
\hline CalcTotal & 100.79 & 100.77 & 99.15 & 99.47 & 99.89 & 99.61 & 99.17 & 99.55 & 100.13 & 99.8 & 98.68 & 99.32 & 99.12 & 99.61 & 99.98 & 99.2 & 99.35 & 98.93 & 98.88 \\
\hline Mg\# & 90.27 & 90.356 & 91.456 & 92.089 & 90.238 & 60.499 & 88.898 & 84.106 & 87.08 & 81.541 & 88.453 & 89.395 & 86.652 & 91.258 & 88.264 & 80.068 & 41.905 & 34.768 & 32.417 \\
\hline
\end{tabular}

Table 5 (continued).

\begin{tabular}{|c|c|c|c|c|c|c|c|c|c|c|c|c|}
\hline \multirow{2}{*}{$\begin{array}{l}\text { Sample: } \\
\text { Mineral: }\end{array}$} & \multicolumn{5}{|c|}{$920 \mathrm{D}-18 \mathrm{R}-3,122-127 \mathrm{~cm}$} & \multicolumn{7}{|c|}{$920 \mathrm{D}-22 \mathrm{R}-5,132-141 \mathrm{~cm}$} \\
\hline & Opx & $\mathrm{Cpx}$ & OI & $\mathrm{Ol}$ & Ol & Opx & Opx & Opx & $\mathrm{Cpx}$ & $\mathrm{Ol}$ & $\mathrm{Ol}$ & Ol \\
\hline $\mathrm{Na}_{2} \mathrm{O}$ & 0.03 & 0.39 & 0.03 & 0.02 & 0 & 0.01 & 0.03 & 0.02 & 0.27 & 0.01 & 0 & 0.02 \\
\hline $\mathrm{Cr}_{2} \mathrm{O}_{3}$ & 0.81 & 1.35 & 0 & 0.02 & 0.01 & 0.25 & 0.48 & 0.9 & 1.32 & 0 & 0 & 0.02 \\
\hline $\mathrm{MgO}$ & 29.35 & 15.5 & 43.58 & 41.94 & 40.04 & 29.45 & 28.6 & 28.8 & 15.29 & 39.33 & 39.41 & 42.48 \\
\hline $\mathrm{Al}_{2} \mathrm{O}_{3}$ & 3.2 & 5.19 & 0 & 0 & 0.01 & 1.43 & 2.19 & 3.82 & 5.04 & 0.01 & 0 & 0 \\
\hline $\mathrm{SiO}_{2}{ }^{3}$ & 53.62 & 50.6 & 38.92 & 38.59 & 37.7 & 54.86 & 54.46 & 53.68 & 50.75 & 38.75 & 38.66 & 39.11 \\
\hline $\mathrm{CaO}$ & 1.47 & 21.62 & 0.03 & 0.04 & 0.02 & 0.95 & 1.48 & 1.39 & 22.25 & 0.04 & 0.04 & 0.03 \\
\hline $\mathrm{TiO}_{2}$ & 0.06 & 0.12 & 0.01 & 0.02 & 0.02 & 0.41 & 0.25 & 0.06 & 0.09 & 0.04 & 0.03 & 0 \\
\hline $\mathrm{MnO}$ & 0.24 & 0.16 & 0.23 & 0.3 & 0.31 & 0.31 & 0.29 & 0.24 & 0.14 & 0.31 & 0.33 & 0.25 \\
\hline $\mathrm{FeO}$ & 11.22 & 4.52 & 17.02 & 18.9 & 21.23 & $12.5 \mathrm{i}$ & 12.23 & 11.2 & 4.53 & 21.94 & 21.55 & 18.04 \\
\hline $\mathrm{NiO}$ & 0.12 & 0.03 & 0.33 & 0.25 & 0.23 & 0.03 & 0.08 & 0.03 & 0 & 0.22 & 0.19 & 0.29 \\
\hline CalcTotal & 100.13 & 99.49 & 100.17 & 100.07 & 99.56 & 100.21 & 100.09 & 100.15 & 99.68 & 100.65 & 100.2 & 100.25 \\
\hline $\mathrm{Mg} \#$ & 82.339 & 85.933 & 82.024 & 79.824 & 77.078 & 80.763 & 80.649 & 82.09 & 85.746 & 76.159 & 76.528 & 80.762 \\
\hline
\end{tabular}


920B

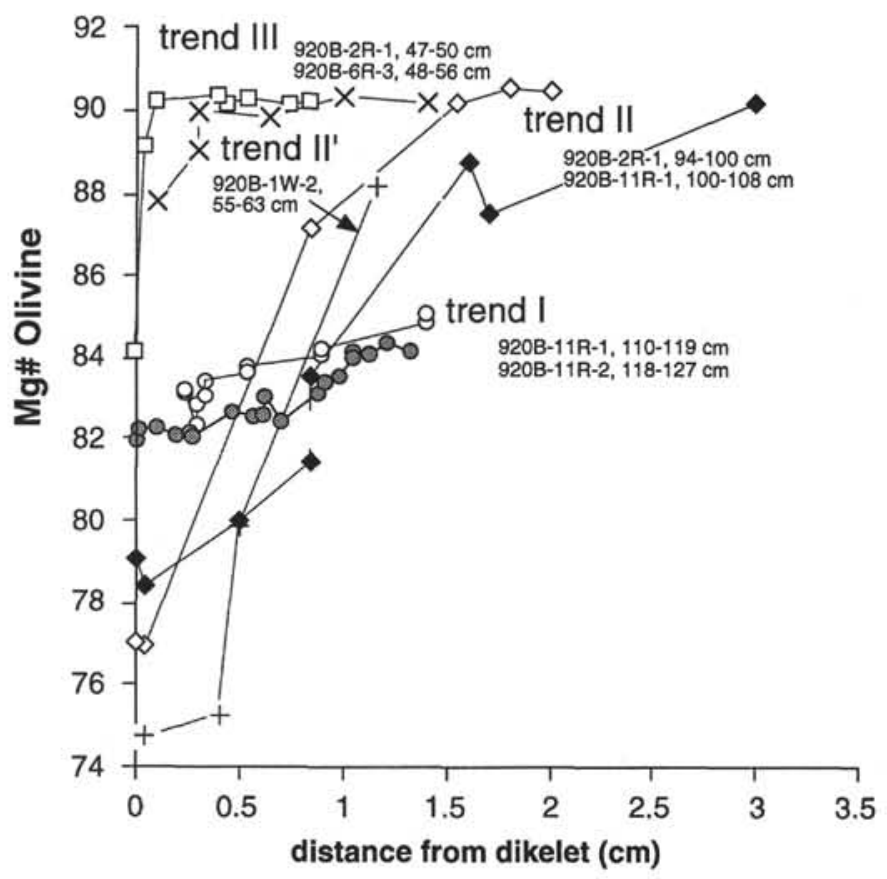

920D

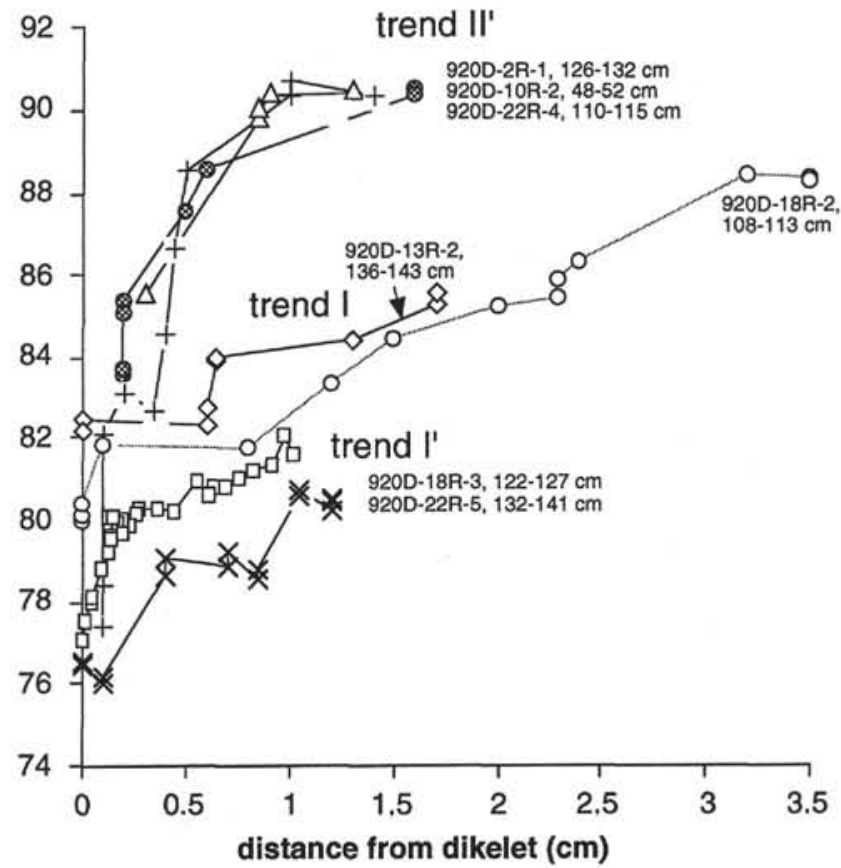

Figure 11. Mg\# variations in olivine from the serpentinized peridotites, with distance to dikelets in 14 samples from Holes 920B and 920D.

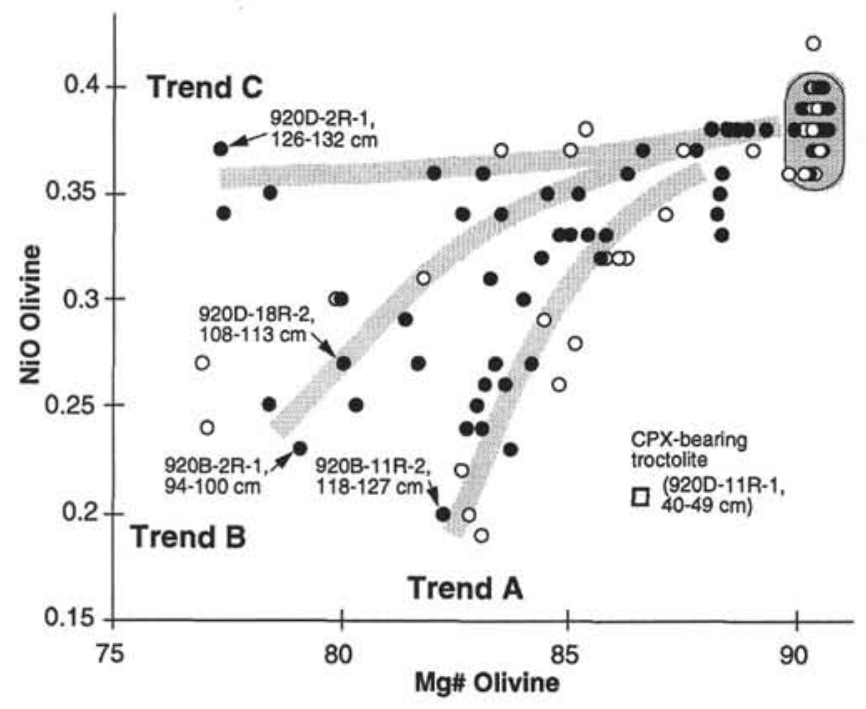

Figure 12. Compositional variations in olivine from the serpentinized peridotites near dikelets. Trends toward decreasing $\mathrm{Mg} \#$ correspond to decreasing distances to the dikelet's margin (see Fig. 11). Data from seven samples are plotted. Solid circles are used for four samples specifically discussed in the text, and an open square for the average olivine composition of a clinopyroxene-bearing troctolite. The shaded area at high $\mathrm{NiO}$ and $\mathrm{Mg} \#$ values is the field for olivine in 15 serpentinized peridotites sampled away from dikelets (Table 5). CPX = clinopyroxene.
Table 6. A summary of chemical modifications observed in olivine and spinel from Site 920 peridotite samples near gabbroic dikelets.

\begin{tabular}{|c|c|c|c|c|}
\hline $\begin{array}{l}\text { Core, section, } \\
\text { interval }(\mathrm{cm})\end{array}$ & Type & A & B & C \\
\hline \multicolumn{5}{|l|}{$153-920 \mathrm{~B}-$} \\
\hline IW-2, 55-63 & 5 & & B-C & \\
\hline $2 \mathrm{R}-1,47-50$ & 5 & III & C & \\
\hline $2 \mathrm{R}-1,94-100$ & 4 & II & B & Low $\mathrm{Ti}$ \\
\hline $5 \mathrm{R}-1,58-62$ & 3 & & & \\
\hline $6 \mathrm{R}-3,48-56$ & 5 & III & C & \\
\hline $8 R-5,108-114$ & 0 & & & High Ti \\
\hline $11 R-1,100-108$ & 4 & II & B & \\
\hline $11 \mathrm{R}-1,110-119$ & 4 & I & A & Low $\mathrm{Ti}$ \\
\hline $11 \mathrm{R}-1,131-140$ & ? & & B-C & \\
\hline $11 \mathrm{R}-2,118-127$ & 4 & I & A & \\
\hline \multicolumn{5}{|l|}{ 153-920D- } \\
\hline $2 \mathrm{R}-1,126-132$ & 5 & $\mathrm{II}^{\prime}$ & C & \\
\hline $4 \mathrm{R}-2,9-13$ & 2 & & & High $\mathrm{Ti}$ \\
\hline $7 \mathrm{R}-1,76-83$ & ? & & $\mathrm{A}$ & High Ti \\
\hline $10 \mathrm{R}-2,48-52$ & ? & $\mathrm{II}^{\prime}$ & C & \\
\hline $12 \mathrm{R}-3,82-86$ & 2 & & & High $\mathrm{Ti}$ \\
\hline $13 R-2,136-143$ & 4 & I & A & Low $\mathrm{Ti}$ \\
\hline $14 \mathrm{R}-2,114-120$ & 2 & & & High $\mathrm{Ti}$ \\
\hline $16 \mathrm{R}-6,126-132$ & $?$ & & B-C & \\
\hline $18 \mathrm{R}-1,38-44$ & ? & & B-C & \\
\hline $18 \mathrm{R}-2,108-113$ & 3 & $\mathrm{I}^{\prime}$ & B & High Ti \\
\hline $18 \mathrm{R}-3,48-50$ & 3 & & A & High $\mathrm{Ti}$ \\
\hline $18 \mathrm{R}-3,83-88$ & ? & & & Low $\mathrm{Ti}$ \\
\hline $18 \mathrm{R}-3,122-127$ & 4 & $\mathrm{I}^{\prime}$ & B & High $\mathrm{Ti}$ \\
\hline $22 \mathrm{R}-4,110-115$ & 5 & II' & $\mathrm{B}-\mathrm{C}$ & \\
\hline $22 \mathrm{R}-5,132-141$ & 4 & $I^{\prime}$ & B & Low $\mathrm{Ti}$ \\
\hline
\end{tabular}

Notes: Roman numbers in column A refer to the olivine Mg\# vs. distance-to-dikelet margin trends defined in Figure 11. Letters in column B refer to the olivine $\mathrm{NiO}$ vs $\mathrm{Mg \#}$ trends defined in Figure 12. Low-Ti and high-Ti trends (column $\mathrm{C}$ ) in spinel are defined in Figure 13. 


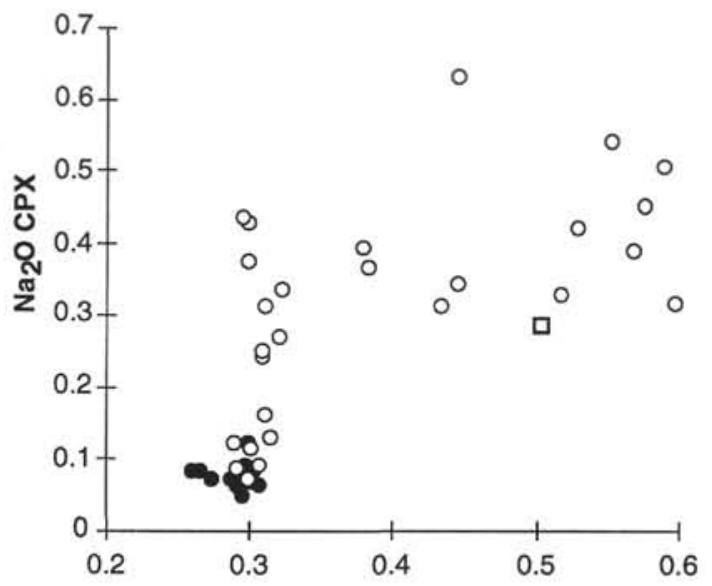

Serpentinized harzburgites

- away from dikelets

- near dikelets

CPX-bearing troctolite (920D-11R-1, 40-49 cm)

Serpentinized dunite (920D-11R-1, 27-32 cm)
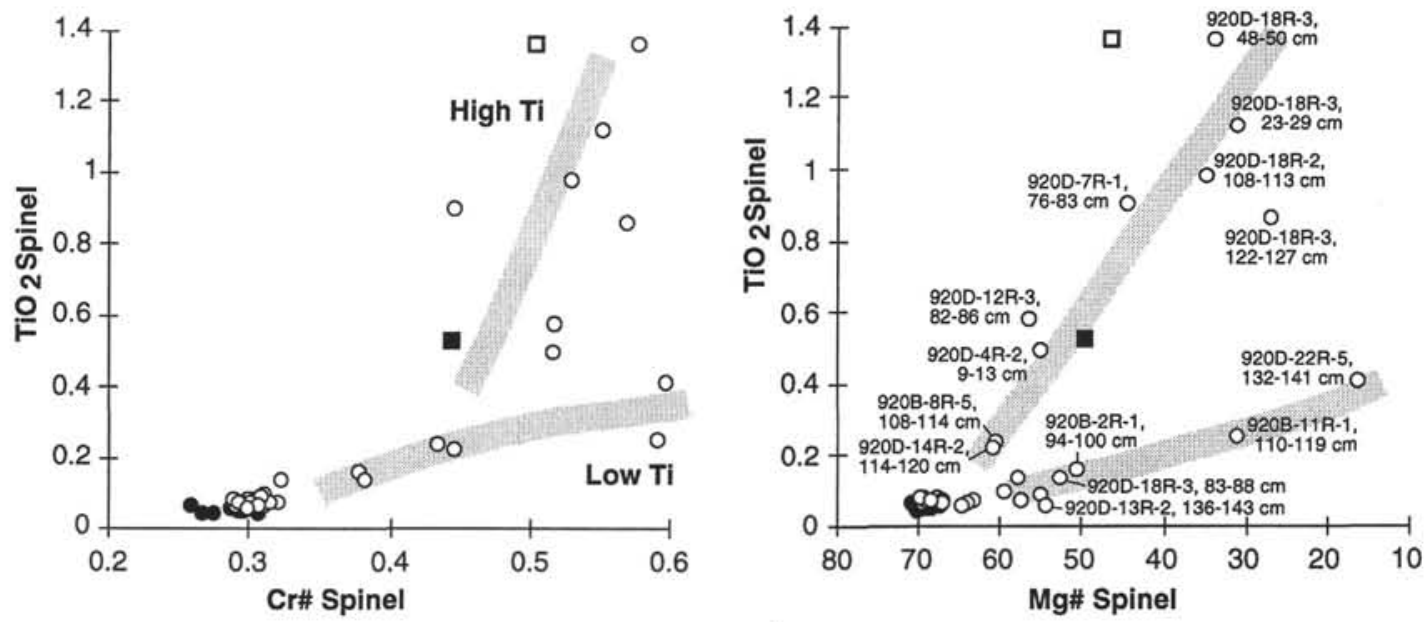

Figure 13. Compositional variations in clinopyroxene (CPX) and spinel in serpentinized peridotite sampled near and away from dikelets at Site 920. Values plotted in these diagrams are average compositions listed in Table 4.

Figure 13A shows that, whereas most near-dikelet, serpentinized peridotite samples contain clinopyroxene that has been enriched in sodium, only some contain spinel that has modified (higher) $\mathrm{Cr} \#$. The common characteristic of these high spinel $\mathrm{Cr} \#$ samples is that they contain plagioclase (Table 6), in impregnation lenses, in reaction rims between spinel and pyroxene (Fig. $5 \mathrm{E}$ ), or as dynamically recrystallized neoblasts.

Spinels near dikelets are variably enriched in iron and in titanium (Fig. 13B, 13C). Three groups of samples can be distinguished: one in which moderate $\mathrm{Cr} \#$ and $\mathrm{Mg} \#$ variations in spinels are accompanied by great variations in titanium content ("high Ti" trend), one in which $\mathrm{TiO}_{2}$ content in spinels remains below $0.4 \%$, even for high $\mathrm{Cr} \#$ and low Mg\# values ("low Ti" trend), and, finally, one in which spinel has retained unmodified compositions. This last group mostly includes samples with type 5, zircon-bearing dikelets. The "high Ti" trend includes, at the moderate $\mathrm{TiO}_{2}$ content end $(0.2 \%-0.6 \%)$, spinels from serpentinized peridotites that contain type 2 plagioclase and clinopyroxene impregnation lenses and dikelets, and from Sample 153-153-920B-8R-5, 108-114 cm (clinopyroxene lens). The highest titanium contents $(0.8 \%-1.4 \%)$ are found in spinels from the clinopyroxene-bearing troctolite (Fig. 5D) and in spinels that are near type 3 or 4 dikelets, and are in contact with interstitial plagioclase, titanium-rich clinopyroxene (Fig. 9), and amphibole. Many samples with these titanium-rich spinels come from Core 153-920D-18R (Fig 2). Spinels from the serpentinized dunite and clinopyroxene-bearing troctolite in Core 153-920D-11R (Fig. 6) also plot on this "high Ti" trend. Spinels in serpentinized peridotite near other type 3 or 4 dikelets belong to the "low Ti" trend. In Sample 153-920D-18R-2, 108$113 \mathrm{~cm}$, which contains spinels plotting in the "high Ti" trend, there is a decrease in titanium content, both in spinels and in clinopyroxenes, from the plagioclase, clinopyroxene, and amphibole dikelets that cut the sample, toward the gabbroic interval in Sample 153920D-18R-2, 103-106 cm (Fig. 2).

\section{DISCUSSION AND CONCLUSION}

The primary conclusion of this paper is that the gabbroic rocks that intruded the ultramafic rocks drilled at Site 920 are texturally, mineralogically, and chemically diverse. In terms of mineralogical and chemical diversity, they compare with gabbroic rocks drilled near the Southwest Indian Ridge (Site 735, Leg 118; Fig. 7). They are also similar (Cannat, Ceuleneer, et al., this volume; Ross and Elthon, Chapter 17, this volume) to the gabbroic rocks that form extensive outcrops a few tens of kilometers north of Site 920 and have been drilled at Sites 921-924 (Fig. 1). This mineralogical and chemical di- 
versity suggests that gabbroic rocks at Site 920 crystallized as cumulates or as trapped melts from magmas that had undergone variable degrees of crystal fractionation and differentiation before crystallizing in the ultramafic rocks. Similar, although not as comprehensively sampled, suites of rocks have been recovered as dikelets in serpentinized peridotites in the $15^{\circ} \mathrm{N}$ region of the Mid-Atlantic Ridge (Cannat and Casey, 1995), and in large offset fracture zones from the East Pacific Rise (Constantin et al., 1995). From their texture, from the shape of their contacts with the host ultramafic rocks, and also from the chemical modifications induced in the ultramafic host rock, it is possible to propose a relative chronology for the crystallization of the variably evolved gabbroic rocks cored at Site 920 . In the following discussion, we make the distinction between melts that travelled in impregnation lenses, dikes, and dikelets, reacted with the host ultramafic rocks, and finally crystallized the gabbros and the gabbros themselves. Additional data on modal and trace-element compositions are needed, however, to constrain the nature (cumulate or trapped liquid) of the various gabbroic types discussed in this paper and to model the corresponding melt compositions.

\section{Type 0, 1, and 2 Magmatic Rocks}

The earliest melts to circulate in the Site 920 ultramafic rocks produced the "type 0" clinopyroxene-impregnation lenses (Fig. 3A). Although generally undeformed, these impregnation lenses are concordant with the spinel foliation in the ultramafic rocks and were therefore probably emplaced when asthenospheric flow had just stopped in these rocks, presumably at the very top of the axial asthenospheric upflow zone (Ceuleneer and Cannat, this volume). Clinopyroxenes in these impregnation lenses are either compositionally similar to residual clinopyroxene in the peridotites, or enriched in iron and sodium in the thicker impregnation lenses. We propose that the presence of this sodium-rich clinopyroxene allowed for the plagioclase- and olivine-forming reaction shown in Figure 5E to take place.

Next came plagioclase and clinopyroxene "type 2 " impregnating dikelets (Fig. 3D) that are also undeformed, but generally discordant with the spinel foliation in the ultramafic rocks. These contain magnesium-rich clinopyroxene and plagioclase with high anorthite contents, and do not affect olivine compositions in the host peridotite. The gabbroic interval in Core 153-920D-11R (Fig. 6) is the only thick "type 2" interval we have recovered. It occurs between two screens of serpentinized dunite that we interpret as zones of reaction between the melt and its ultramafic host. These dunite screens are a few decimeters thick. Only the upper contact between serpentinized harzburgite and dunite is preserved in the core. It is subhorizontal, near parallelism with the spinel foliation that is present both in the serpentinized harzburgite, and in the serpentinized dunite. There are two other intervals of similar serpentinized dunite in the core from Hole 920B (intervals 153-920B-12R-1, 120-135 cm, and 153-920B-12R$2,133-148 \mathrm{~cm}$ ), but no gabbro has been recovered there. The upper margin of one of these serpentinized dunites makes a $70^{\circ}$ angle with the spinel foliation (fig. 69 in Shipboard Scientific Party, 1995).

The serpentinized dunite in Core 153-920D-11R has no unaltered olivine. Its spinels (Fig. 13) are, however, compositionally similar to those of other ophiolitic or abyssal dunites that are interpreted as melt-rock reaction products (Dick, 1977; Quick, 1981; Nicolas, 1986; Kelemen et al., 1992; 1995; Dick and Natland, 1996). The thin interval of clinopyroxene-bearing troctolite near the gabbro (Fig. 6) contains spinels that are elongated (Fig. 5D) parallel with the spinel foliation in other parts of the core. Clinopyroxene in this interval has high $\mathrm{Mg} \#$, low sodium, relatively low titanium, and variable chromium contents (Fig. 9). Aside from chromium, it is compositionally similar to clinopyroxene in the nearby gabbro. Anorthite content in plagioclase is also similar, and high (Fig. 7). We propose that the clinopyroxene-bearing troctolite is an impregnated dunite, formed along the margins of the gabbro dike. The coarse grain size of this very primitive gabbro, and the decimeter-scale inferred reaction zone, suggest that it was emplaced in ultramafic rocks that were still quite hot. The lack of deformation in the gabbro and the angular discordance between the dunitic interval and the spinel foliation in Section 153-920B-12R-1 suggest, however, that this emplacement took place above the domain of axial asthenospheric upflow, in the lower lithospheric mantle.

\section{Type 3 and 4 Magmatic Rocks}

Gabbroic and websteritic, "type 3 and 4" dikes and dikelets (plagioclase, clinopyroxene, orthopyroxene in type 4 , and iron-titanium oxides, apatite, or titanium-rich hornblende) are not screened by dunites. This indicates that the melts circulating in these dikelets were not saturated in olivine. This is, of course, consistent with the crystallization of orthopyroxene in many of these dikelets. This is also consistent with the occurrence of incompatible-element-rich accessory minerals and of relatively iron-rich clinopyroxene in some dikelets (Fig. 7), which suggest relatively high degrees of fractionation for magmas travelling in these dikelets. Melts circulating in type 3 and 4 gabbroic intervals have reacted with the ultramafic host rock over distances of 2 to more than $5 \mathrm{~cm}$ (Fig. 11). This reaction affected the iron content of olivine and spinel, the nickel content of olivine, the sodium content of clinopyroxene, and the chromium and titanium contents of spinel (Figs. 11-13; Tables 4-6). The thickness of the reaction zone appears to be a function of the distance over which melt from the dikelet could impregnate the host peridotite. The amplitude of the chemical modifications induced is variable (e.g., trends I, I', and II in Fig. 11, and high-Ti, low-Ti trends in Fig. 13), probably reflecting a variability in the composition of the impregnating melt.

Thick type 3 and 4 gabbroic intervals at Site 920 have mineralogy and mineral compositions consistent with progressive differentiation of a tholeiitic melt (Fig. 7). Clinopyroxene Mg\# values in these thick intervals are between $70 \%$ and $77 \%$, corresponding to plagioclase An contents between $40 \%$ and $56 \%$ (Fig. 7). The thick gabbroic interval at the base of Hole $920 \mathrm{~B}$ contains type 3 and 4 rocks with substantially more fractionated mineral compositions (Fig. 7). By contrast, thin type 3 and 4 gabbroic and websteritic dikelets contain pyroxene that has anomalously high $\mathrm{Mg} \#$ values (up to $88 \%$; Fig. 7). The same is true, a fortiori, for the thin dikelets of gabbronorite that contain zircon (type 5 dikelets) and high $\mathrm{Mg \#}$ clinopyroxene (Fig. 7).

High $\mathrm{Mg} \#$ in clinopyroxenes from types 3, 4, and 5 thin dikelets are reflected in magmatic amphiboles from these dikelets, which also have high chromium content (Fig. 8). We propose that these chemical peculiarities are the counterpart, in the magma that crystallized the gabbros, of the iron enrichment observed in the ultramafic rocks near the dikelets. $\mathrm{Mg} \#$ in clinopyroxenes from thin types 3,4 , and 5 dikelets would then be a function of the initial melt composition, of the melt/rock ratio and of its evolution through time as melt circulated in the dikelet. Other factors that ought to be involved but that we have not evaluated for this paper are the production of heat during melt crystallization and the variations in melt solidus temperatures associated with its enrichment in magnesium as it reacted with the peridotite. The melt/rock ratio would depend on the volume of melt circulating in the dikelet and on the thickness of the melt-rock reaction zone that was presumably controlled by the temperature of the ultramafic rocks (greater temperature allowing for intergranular melt percolation to greater distances from the dikelets).

For example, the $\mathrm{Mg \#}$ decrease in olivine near dikelets follows the same trend (trend I; Fig. 11) in Samples 153-920B-11R-1, 110$119 \mathrm{~cm}$ (Fig. 3C) and 153-920D-13R-2, 136-143 cm (fig. 8 in Shipboard Scientific Party, 1995), whereas igneous clinopyroxenes in the dikelets that cut these samples have very different $\mathrm{Mg \#}$ : high $\mathrm{Mg} \#$ (83\% average; Table 2) in Sample 153-920B-11R-1, 110-119 cm, and relatively low $\mathrm{Mg} \#$ (70\% to 76\%; Table 2) in Sample 153-920D$13 \mathrm{R}-2,136-143 \mathrm{~cm}$. The same is observed for Samples 153-920B- 


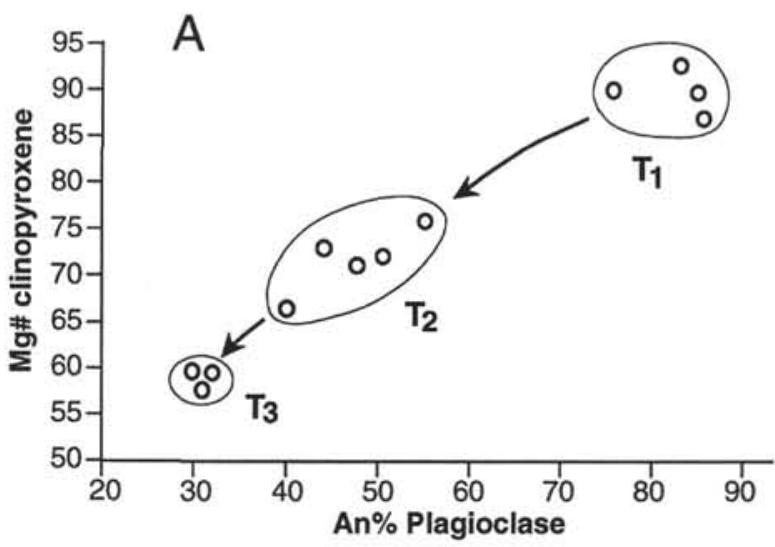

B
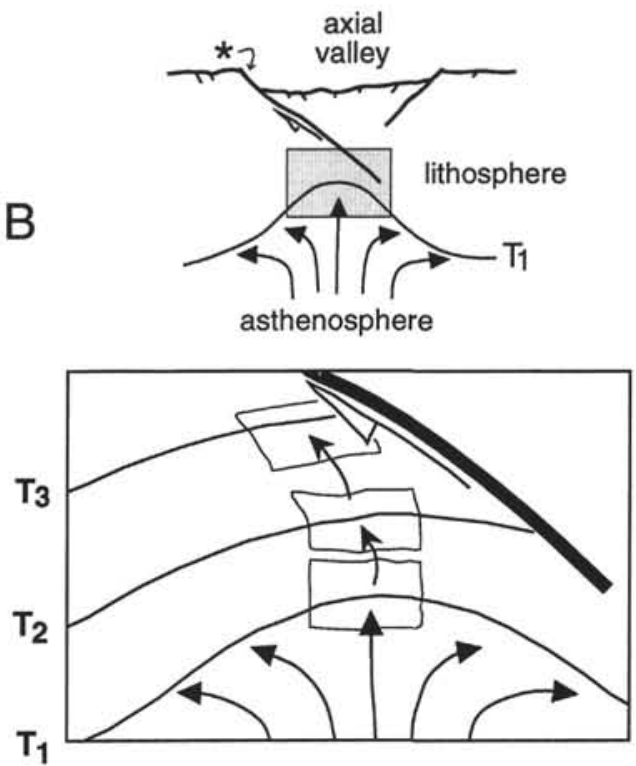

Figure 14. A schematic model for the crystallization of gabbroic rocks in the ultramafic rocks drilled at Site 920. The diagram in $\mathbf{A}$ is a sketch version of Figure 7 , showing the three groups of plagioclase and clinopyroxene compositions measured in Site 920 coarse-grained magmatic rocks. To each group of composition corresponds a melt solidus temperature $\left(\mathrm{T}_{1}, \mathrm{~T}_{2}\right.$, or $\left.\mathrm{T}_{3}\right)$ that decreases as fractionation proceeds. The sketches in $\mathbf{B}$ show the context of crystallization proposed for these magmatic rocks, in the axial mantle lithosphere (the star shows the location of Site 920 on the axial valley wall). These sketches recall the model proposed by Cannat and Casey (1995) for gabbroic intrusive rocks in serpentinized peridotites of the $15^{\circ} 20^{\prime} \mathrm{N}$ region of the Mid-Atlantic Ridge. Natural seismicity in the Mid-Atlantic Ridge axial valley south of Site 920 suggests that the brittle part of the lithosphere there is about 7 km thick (Toomey et al., 1988). The lithosphere as it is drawn in B also includes the lower, ductile part and may therefore be thicker. The enlarged inset shows the upward displacement of the mantle region that we think was ultimately emplaced at Site 920 . Melts of progressively more fractionated compositions crystallized as this mantle region cooled below their respective solidus temperatures (see text). The most evolved melts crystallized in lithospheric mantle that was undergoing localized ductile deformation, possibly related to minor splays of the large normal shear zone (or shear zones) inferred to accommodate the uplift of deep lithospheric material in the MARK area.

2R-1, 94-100 cm (average clinopyroxene $\mathrm{Mg} \#$ in dikelet: $83.2 \%$; Table 2), and 153-920B-11R-1, 100-108 cm (average clinopyroxene $\mathrm{Mg \#}$ in dikelet: $66.8 \%$; Table 2) that both show a trend II decrease of the near-dikelet olivine Mg\# (Fig. 11). Our interpretation is that these differences in igneous clinopyroxene composition between dikelets that have induced the same type of reaction in their peridotite host reflect differences in the melt/rock ratio. We therefore propose that igneous clinopyroxenes in Samples 153-920B-11R-1, 110-119 cm, and 153-920B-2R-1, 94-100 cm, have high Mg\# because they crystallized from small volumes of melt that had reacted with the peridotite. By contrast, we propose that lower Mg\#, igneous clinopyroxenes from Samples 153-920D-13R-2, 136-143 cm, and 153-920B-11R-1, $100-108 \mathrm{~cm}$, crystallized in dikelets that really acted as conduits for melt circulation.

Such melt/rock reactions, the percolation of melt into the peridotites, and the equilibrium textures that developed between the dikelet minerals and the minerals from the peridotites (Fig. 5F) are all indications that type 3 and 4 gabbroic rocks crystallized in peridotites that were still hot. In fact, their temperature was probably not much below the solidus temperatures of the relatively evolved melts that crystallized type 3 and 4 lithologies. This is supported by the observation that the minimum $\mathrm{Mg} \#$ measured in igneous clinopyroxene from dikelets that have induced trend I or I' (higher temperature) modifications in olivine from their host peridotite (Fig. 11) is $71.9 \%$ (in Sample 153-920D-18R-2, 103-106 cm; Table 2), higher than the minimum $\mathrm{Mg \#}$ measured in igneous clinopyroxene from dikelets that have induced trend II (lower temperature) modifications (64\% in Sample 153-920B-11R-1, 100-108 cm; Table 2).
Titanium-rich spinel (high Ti trend in Fig. 13) occurs in the peridotites near some, but not all, type 3 and 4 dikelets (Table 6; Fig. 13). These titanium-rich spinels are associated with plagioclase, magnesium, and titanium-rich clinopyroxene (Fig. 9), and with titaniumrich hornblende that impregnate the peridotite near the dikelets. In some cases, the igneous clinopyroxene in the dikelet also has high magnesium and titanium contents (e.g., Sample 153-920D-18R-3, $48-50 \mathrm{~cm}$; Fig. 2; Table 3). In other cases, igneous clinopyroxene in the nearby dikelet has moderate $\mathrm{Mg} \#$ and moderate to low titanium content (e.g., Samples 153-920D-18R-2, 103-106 cm, and 153$920 \mathrm{D}-18 \mathrm{R}-3,122-127 \mathrm{~cm}$ ). We propose that, in these cases, the melt/ rock reactions that caused the spinel to become enriched in titanium took place during an earlier stage of melt circulation, in or near the dikelet. This is consistent with the decreasing titanium content in high Mg\# impregnating clinopyroxenes in Sample 153-920D-18R-2, 108-113 cm, toward the dikelet in Sample 153-920D-18R-2, 103$106 \mathrm{~cm}$ (Fig. 2). At this point, we believe more detailed work is needed to determine whether this early, magnesium- and titanium-rich melt was something altogether different from the melts that crystallized type 3 and 4 gabbroic rocks, or whether there is some mechanism by which extensive reaction with the peridotites resulted in a relative enrichment of the impregnating melt in titanium.

Macroscopic core descriptions and the observation of many dikelets in thin section suggest that type 3 and 4 gabbroic dikes and dikelets are volumetrically the most abundant in the core from Site 920. We assume, based on similarities between the trends of clinopyroxene $\mathrm{Mg} \#$ vs. plagioclase An contents in gabbroic rocks from Sites 920, 735 (Fig. 7), and 921 to 924 (Cannat, Ceuleneer, et al., this vol- 
ume; Ross and Elthon, Chapter 17, this volume) that type 3 and 4 gabbroic rocks at Site 920 crystallized from melts that had already undergone significant fractionation. Similarly evolved gabbroic lithologies represent less than $30 \%$ of the gabbroic core recovered at Sites 735 (Southwest Indian Ridge; Bloomer et al., 1991) and 921923 (MARK area; Cannat, Ceuleneer, et al., this volume). This means that a significant length of less evolved gabbros may be missing from the core recovered at Site 920 .

\section{Type 5 Magmatic Rocks}

Gabbroic rocks that contain zircon have induced limited reactions in the host peridotite. Olivine $\mathrm{Mg \#}$ is modified over less than $1.5 \mathrm{~cm}$ from these dikelets, clinopyroxene near the dikelets is variably enriched in sodium, and spinel is generally not modified (Figs. 11-13). However, as in the case of types 3 and 4 dikelets, thin zircon-bearing dikelets commonly contain high $\mathrm{Mg} \#$ clinopyroxene. This suggests that melt/rock ratios in these dikelets were most commonly low.

Intervals of mylonitic deformation in the host peridotites systematically contain zircon-bearing dikelets (Figs. 3B, 5A). Some of these mylonitic intervals contain both deformed and undeformed magmatic minerals, suggesting that deformation occurred for the most part with some residual melt present in the shear zone. The presence of this melt and the dynamic recrystallization of olivine, orthopyroxene and clinopyroxene in the peridotite, and of plagioclase, clinopyroxene, orthopyroxene, and brown hornblende in the dikelets (Fig. 5A) indicate that mylonitization occurred at temperatures near the solidus of the residual melt. The fine-grained texture of recrystallized assemblages suggests high deviatoric stresses (Ceuleneer and Cannat, this volume). This leads us to propose that type 5 magmatic rocks in Site 920 mylonites crystallized within the ductile part of the axial mantle lithosphere.

It therefore appears that the chemical diversity of magmatic rocks at Site 920 is reflected in their order of crystallization in the peridotites, the most primitive rocks crystallizing first, and the most fractionated ones, last. It also appears that these magmatic rocks crystallized in peridotites that were in each case close to the melt solidus temperature. Although it is not surprising that a melt of a given composition does not start crystallizing in a medium that is hotter than its solidus, there is no reason why melts should not be intruded in rocks substantially colder than their solidus. We believe that the fact that this did not happen at Site 920 is an indication that the gabbroic rocks there did not crystallize from melts that were far travelled, but rather from melts that got trapped into the axial lithospheric mantle (above the domain of asthenospheric upflow), and underwent fractionation as this particular piece of mantle was cooled and tectonically uplifted (Fig. 14). Of course, we do not mean to imply that there were no magmas travelling through the axial mantle lithosphere to feed gabbroic bodies and lava flows in the oceanic crust. We simply conclude that channels for such magmas have not been sampled in the ultramafic rocks from Site 920. Coarse-grained magmatic rocks at this site only "made it" to the crust by way of being tectonically uplifted together with their ultramafic host rock.

\section{ACKNOWLEDGMENTS}

We thank Peter Kelemen and another anonymous reviewer for their helpful reviews. We also thank our colleagues from the Shipboard Scientific Party, as well as the captain, the crew, and the drilling and technical staff of the JOIDES Resolution. Financial support for our work was provided by INSU-CNRS ("Géosciences marines" program).

\section{REFERENCES}

Aumento, F., Melson, W.G., et al., 1977. Init. Repts. DSDP, 37: Washington (U.S. Govt. Printing Office).

Auzende, J.M., Cannat, M., Gente, P., Henriet, J.P., Juteau, T., Karson, J.A., Lagabrielle, Y., and Tivey, M.A., 1993. Deep layers of mantle and oceanic crust exposed along the southern wall of the Kane Fracture Zone: submersible observations. C.R. Acad. Sci. Ser. 2, 317:1641-1648.

Bonatti, E., Peyve, A., Kepezhinskas, P., Kurentsova, N., Seyler, M., Skolotnev, S., and Udintsev, G., 1992. Upper mantle heterogeneity below the Mid-Atlantic Ridge, $0^{\circ}-15^{\circ} \mathrm{N}$. J. Geophys, Res., 97:4461-4476.

Bougault, H., Cande, S.C., et al., 1985. Init. Repts. DSDP, 82: Washington (U.S. Govt. Printing Office).

Cannat, M., 1993. Emplacement of mantle rocks in the seafloor at mid-ocean ridges. J. Geophys. Res., 98:4163-4172.

Cannat, M., and Casey, J.F., 1995. An ultramafic lift at the Mid-Atlantic Ridge: successive stages of magmatism in serpentinized peridotites from the $15^{\circ} \mathrm{N}$ region. In Vissers, R.L.M., and Nicolas, A. (Eds.), Mantle and Lower Crust Exposed in Oceanic Ridges and Ophiolites: Dordrecht (Kluwer), 5-34.

Cannat, M., Mével, C., Maia, M., Deplus, C., Durand, C., Gente, P., Agrinier, P., Belarouchi, A., Dubuisson, G., Humler, E., and Reynolds, J., 1995. Thin crust, ultramafic exposures and rugged faulting patterns at the Mid-Atlantic Ridge $\left(22^{\circ}-24^{\circ} \mathrm{N}\right)$. Geology, 23:49-52.

Cannat, M., Mével, C., and Stakes, D., 1991. Normal ductile shear zones at an oceanic spreading ridge: tectonic evolution of Site 735 gabbros (southwest Indian Ocean). In Von Herzen, R.P., Robinson, P.T., et al., Proc. ODP, Sci. Results, 118: College Station, TX (Ocean Drilling Program), 415-429.

Constantin, M., Hékinian, R., Ackerman, D., and Stoffers, P., 1995. Mafic and ultramafic intrusions into upper mantle peridotites from fast spreading centers of the Easter Microplate (South East Pacific). In Vissers, R., and Nicolas, A. (Eds.), Mantle and Lower Crust Exposed in Oceanic Ridges and in Ophiolites: Rotterdam (Kluwer), 71-120.

Dick, H.J.B., 1977. Evidence of partial melting in the Josephine peridotite. In Dick, H.J.B. (Ed.), Magma Genesis. Bull.-Oreg. Dep. Geol. Miner. Ind., 96:59-62.

, 1989. Abyssal peridotites, very slow spreading ridges and ocean ridge magmatism. In Saunders, A.D., and Norry, M.J. (Eds.), Magmatism in the Ocean Basins. Geol. Soc. Spec. Publ. London, 42:71-105.

Dick, H.J.B., and Natland, J.H., 1996. Late-stage melt evolution and transport in the shallow mantle beneath the East Pacific Rise. In Mével, C., Gillis, K.M., Allan, J.F., and Meyer, P.S. (Eds), Proc. ODP, Sci. Results, 147: College Station, TX (Ocean Drilling Program), 103-134.

Dick, H.J.B., Thompson, G., and Bryan, W.B., 1981. Low angle faulting and steady state emplacement of plutonic rocks at ridge-transform intersections. Eos, 62:406.

Gente, P., Pockalny, R., Durand, C., Deplus, C., Maia, M., Ceuleneer, G., Mével, C., Cannat, M., and Laverne, C., 1995. Characteristics and evolution of the segmentation of the Mid-Atlantic Ridge between $20^{\circ} \mathrm{N}$ and $24^{\circ} \mathrm{N}$ during the last 10 million years. Earth Planet. Sci. Lett., 129:5571.

Karson, J.A., 1990. Seafloor spreading on the Mid-Atlantic Ridge: implications for the structure of ophiolites and oceanic lithosphere produced in slow-spreading environments. In Malpas, J., Moores, E.M., Panayiotou, A., and Xenophontos, C. (Eds.), Ophiolites: Oceanic Crustal Analogues: Proc. Symp. "Troodos 1987": Nicosia, Cyprus (Minist. Agric. Nat. Resour.), 547-555.

Karson, J.A., Thompson, G., Humphris, S.E., Edmond, J.M., Bryan, W.B., Brown, J.R., Winters, A.T., Pockalny, R.A., Casey, J.F., Campbell, A.C., Klinkhammer, G., Palmer, M.R., Kinzler, R.J., and Sulanowska, M.M., 1987. Along-axis variations in seafloor spreading in the MARK area. Nature, 328:681-685.

Keleman, P.B., Dick, H.J.B., and Quick, J.E., 1992. Formation of harzburgite by pervasive melt/rock reaction in the upper mantle. Nature, 358:635641 .

Kelemen, P.B., Shimizu, N., and Salters, V.J.M., 1995. Extraction of midocean-ridge basalt from the upwelling mantle by focused flow of melt in dunite channels. Nature, 375:747-753.

Mével, C., Cannat, M., Gente, P., Marion, E., Auzende, J.-M., and Karson, J.A., 1991. Emplacement of deep crustal and mantle rocks on the west 
median valley wall of the MARK area (MAR $23^{\circ} \mathrm{N}$ ). Tectonophysics, 190:31-53.

Meyer, P.S., Dick, H.J.B., and Thompson, G., 1989. Cumulate gabbros from the Southwest Indian Ridge, $54^{\circ} \mathrm{S}-7^{\circ} 16^{\prime} \mathrm{E}$ : implications for magmatic processes at a slow spreading ridge. Contrib. Mineral. Petrol., 103:4463.

Nicolas, A., 1986. A melt extraction model based on structural studies in mantle peridotites. J. Petrol., 27:999-1022.

Ozawa, K., Meyer, P.S., and Bloomer, S.H., 1991. Mineralogy and textures of iron-titanium oxide gabbros and associated olivine gabbros from Hole 735B. In Von Herzen, R.P., Robinson, P.T., et al., Proc. ODP, Sci. Results, 118: College Station, TX (Ocean Drilling Program), 41-73.

Quick, J.E., 1981. The origin and significance of large, tabular dunite bodies in the Trinity peridotite, northern California. Contrib. Mineral. Petrol., $78: 413-422$.

Shipboard Scientific Party, 1979. Site $395: 23^{\circ}$ N. Mid-Atlantic Ridge. In Melson, W.G., Rabinowitz, P.D., et al., Init. Repts. DSDP, 45: Washington (U.S. Govt. Printing Office), 131-264.
, 1988. Site 670. In Bryan, W.B., Juteau, T., et al., Proc. ODP, Init. Repts., 109: College Station, TX (Ocean Drilling Program), 203-238.

, 1995. Site 920. In Cannat, M., Karson, J.A., Miller, D.J., et al., Proc. ODP, Init. Repts., 153: College Station, TX (Ocean Drilling Program), 45-119.

Tartarotti, P., Cannat, M., and Mével, C., 1995. Gabbroic dikelets in serpentinized peridotites from the MARK area (Mid-Atlantic Ridge at Kane Fracture Zone). In Vissers, R., and Nicolas, A. (Eds.), Mantle and Lower Crust Exposed in Oceanic Ridges and in Ophiolites: Rotterdam (Kluwer), 35-69.

Toomey, D.R., Solomon, S.C., and Purdy, G.M., 1988. Microearthquakes beneath the median valley of the Mid-Atlantic Ridge near $23^{\circ} \mathrm{N}$ : tomography and tectonics. J. Geophys. Res., 93:9093-9112.

Date of initial receipt: 7 August 1995

Date of acceptance: 25 January 1996

Ms 153SR-013 